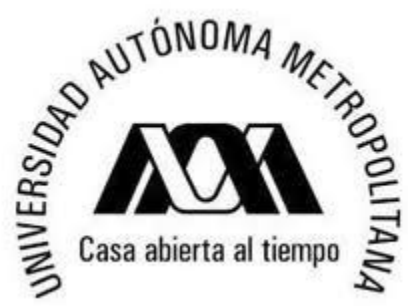

\title{
PARTÍCULAS DE PLATA Y ORO HOSPEDADAS EN MATERIALES POROSOS Y SU EFICIENCIA COMO BACTERICIDAS
}

\author{
TESIS QUE PRESENTA \\ ROBERTO GUERRA GONZÁLEZ \\ PARA OBTENER EL GRADO DE \\ DOCTOR EN CIENCIAS (QUÍMICA)
}

ASESORES:

DR. ENRIQUE JAIME LIMA MUÑOZ

DRA. MARGARITA VINIEGRA RAMÍREZ

UNIVERSIDAD AUTÓNOMA METROPOLITANA-IZTAPALAPA DIVISIÓN DE CIENCIAS BÁSICAS E INGENIERÍA

México, D.F., Enero 2013. 


\section{DEDICATORIA}

A mis padres, como un testimonio de cariño y eterno agradecimiento por mi existencia, valores morales y formación profesional. Porque sin escatimar esfuerzo alguno, han sacrificado gran parte de su vida para formarme y porque nunca podré pagar todos sus desvelos, ni aún con las riquezas más grandes del mundo. Por lo que soy y por todo el tiempo que les robé pensando en mí...

A mi esposa, de quien he recibido apoyo en todo momento.

A todos los que directa e indirectamente ayudaron a la realización de este proyecto.

A la vida. 


\section{AGRADECIMIENTOS}

A la Universidad Autónoma Metropolitana por haberme dado cobijo y por las lecciones que aprendí en ella, así mismo, por haberme dado su voto de confianzay por todo el apoyo otorgado a mi persona.

A mis maestros que ayudaron en mi formación profesional.

A mis directores de tesis, Dra. Margarita Viniegra Ramírez y Dr. Enrique Jaime Lima por su paciencia, apoyo y confianza en mí como persona y como estudiante.

Gracias por no perder la fe (y si así ha sido), gracias por recuperarla.

Se agradece a PAPIIT-UNAM (IN107110) por el apoyo para la realización de este trabajo.

A la Escuela Nacional de Ciencias Biológicas del Instituto Politécnico Nacional y la Facultad de Químico Farmacobiología de la Universidad Michoacana de San Nicolás de Hidalgo por su apoyo en el otorgamiento de las cepas clínicas.

A mis sinodales: por sus valiosas sugerencias. Gracias por todo su tiempo invertido en la revisión de esta tesis.

A mis hermanos: Ramón, Rebeca y Luis Armando por haberme apoyado todo este tiempo. Gracias por sus consejos y ánimos constantes.

A miamigo José Luis: Gracias por infundirme ánimos en todo momento.

Gracias, eternamente gracias, a todos. 


\section{AGRADECIMIENTO AL CONACYT}

Hago extensivo mi agradecimiento al Consejo Nacional de Ciencia y Tecnología (CONACYT) por haberme otorgado una beca para realizar mis estudios de Doctorado y por el apoyo económico brindado para la compra parte del material que se utilizó en el desarrollo del trabajo, dentro del marco del proyecto de investigación con el número de referencia 128299. 


\section{Resumen}

Se soportaron partículas de plata u oro en zeolitas naturales y sintéticas y se evaluaron como bactericidas de microorganismos de Escherichia coli y Salmonella typhi. Las variables estudiadas fueron la cantidad de plata y oro soportada en las zeolitas y la temperatura de reducción. Los materiales se caracterizaron por Difracción de rayos $X(X R D)$, Resonancia magnética nuclear (NMR-MAS) de ${ }^{29} \mathrm{Si}$ y ${ }^{27} \mathrm{Al}$ y Dispersión de rayos $X$ a ángulos pequeños (SAXS). Los microorganismos se incubaron en caldo de soya tripticaseína, empleando agar selectivo para su detección y cuantificación; la determinación del número de unidades formadoras de colonia (UFC) se hizo con la técnica de conteo de colonias y área de las mismas.

Cantidades de Ag-zeolita y Au-zeolita aproximadamente $0.06 \mathrm{~g} / 18 \mathrm{~mL}$ de cultivo, con una concentración de $0.11 \%$ en peso de plata u oro, eliminaron todas las colonias de Escherichia coli a tiempos de $30 \mathrm{~min}$. Para la eliminación de colonias de Salmonella typhi, se requirió mayor cantidad de muestra biocida $(0.12 \mathrm{~g} / 18 \mathrm{~mL})$ para la eliminación total de la Salmonella typhi en $30 \mathrm{~min}$. 



\section{Contenido}

Capítulo 1. Introducción 1

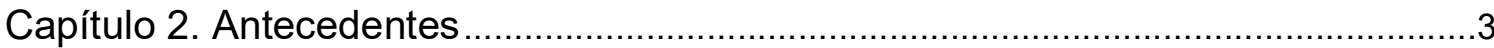

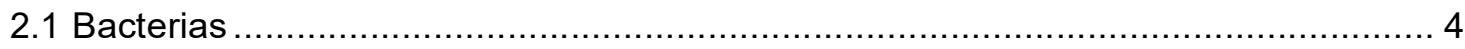

2.1.1 Pared celular de bacterias Grampositivas y Gramnegativas .......................... 5

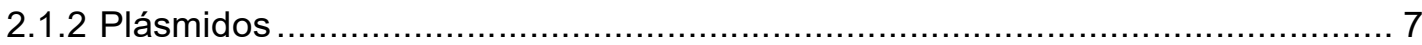

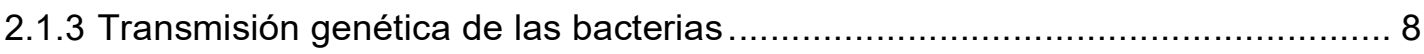

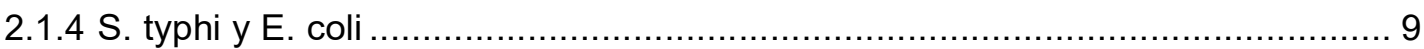

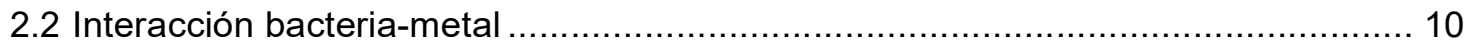

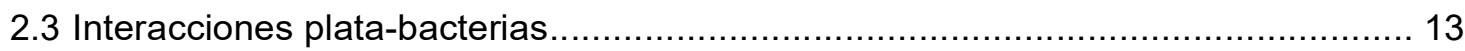

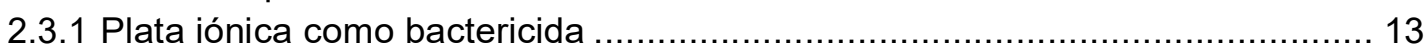

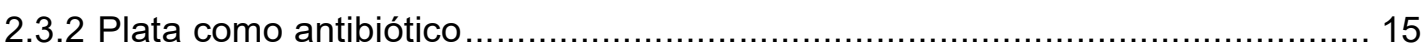

2.3.3 Mecanismos de la plata como bactericida ................................................ 16

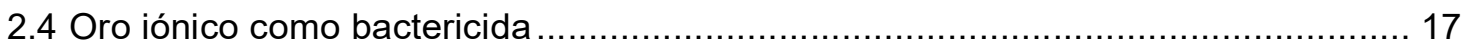

2.5 Partículas metálicas de plata y oro como bactericidas ........................................ 19

2.6 Partículas de Ag y Au soportadas como bactericidas............................................ 19

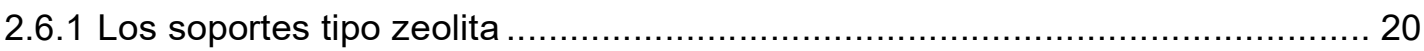

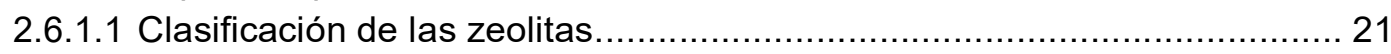

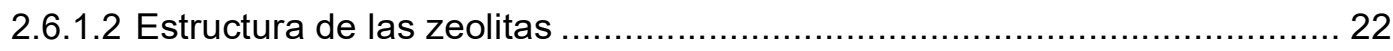

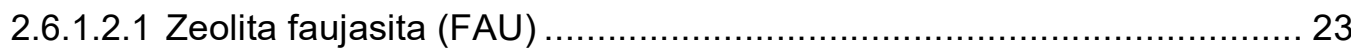

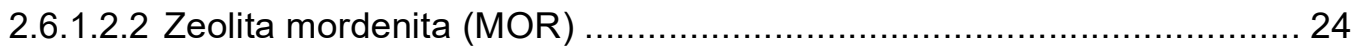

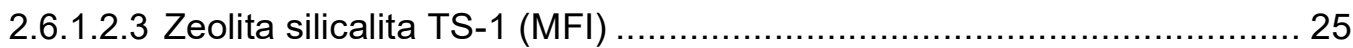

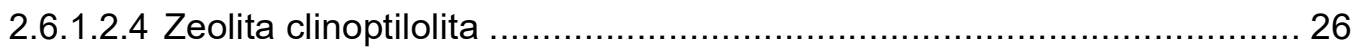

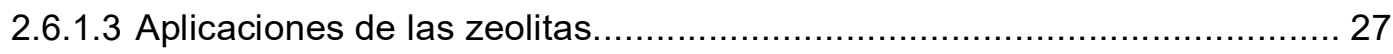

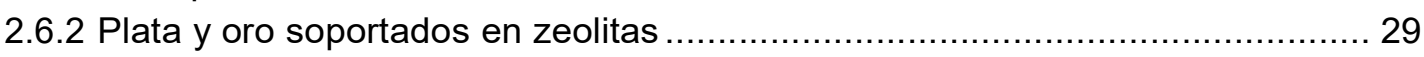

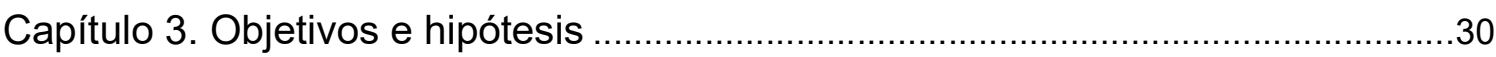

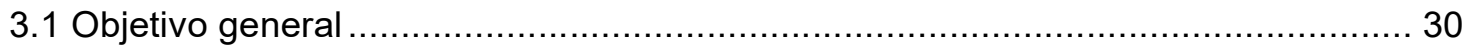

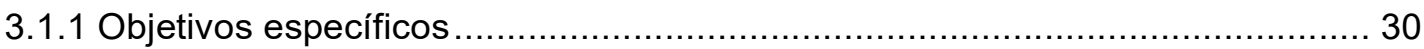

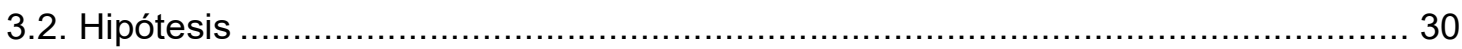

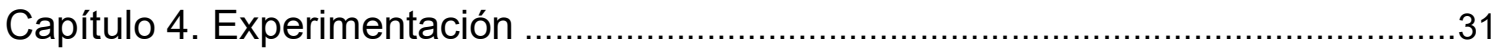

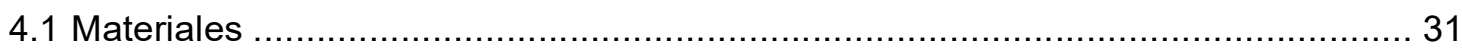

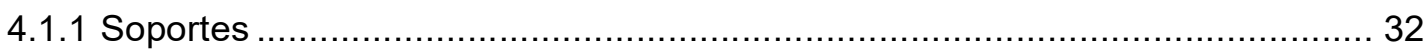

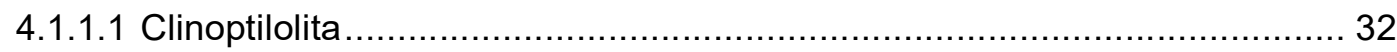

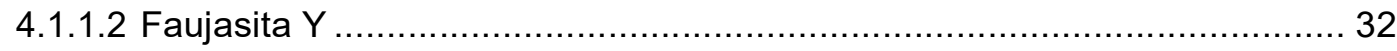

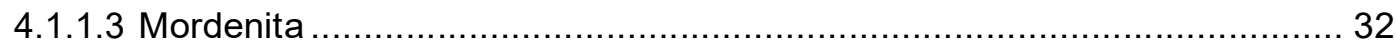

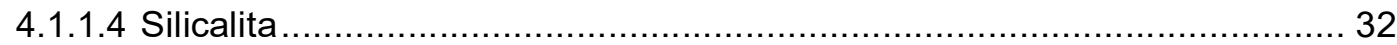

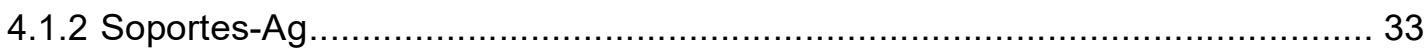

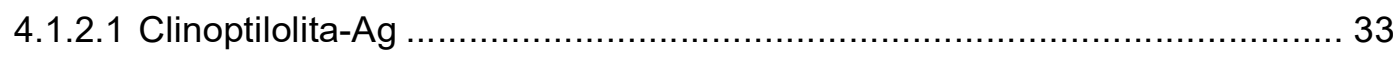




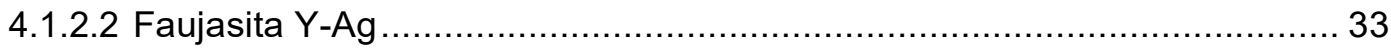

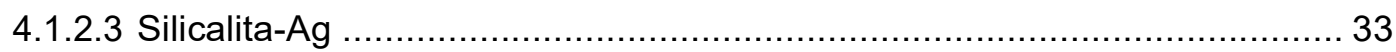

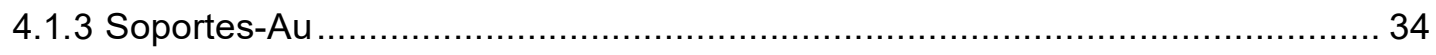

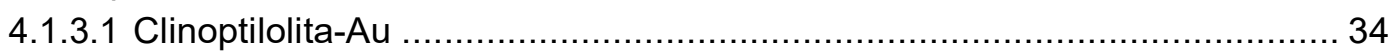

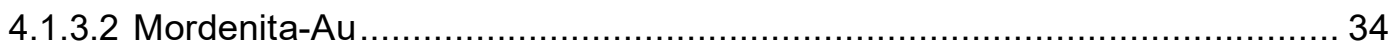

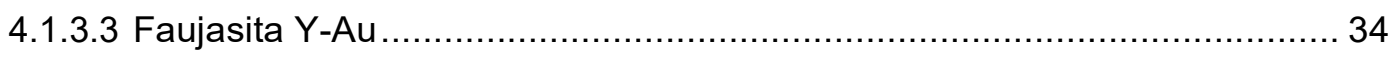

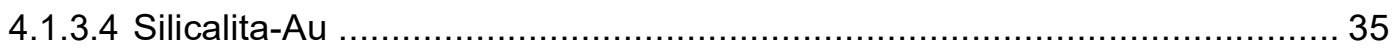

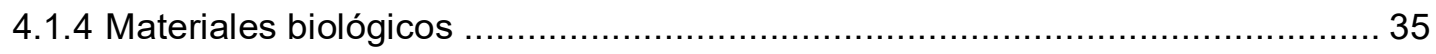

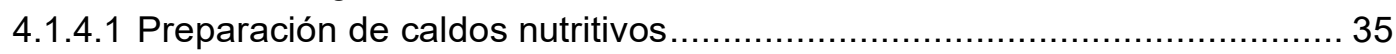

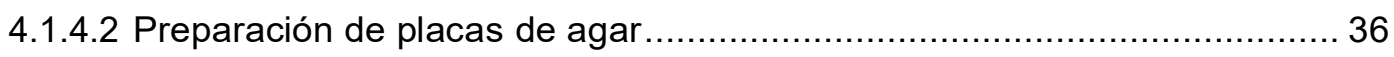

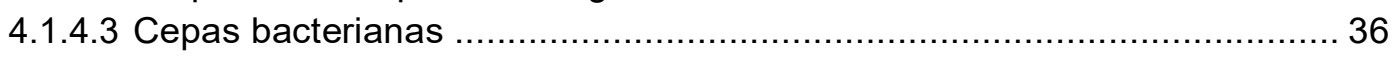

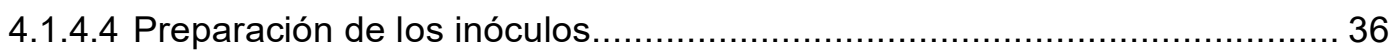

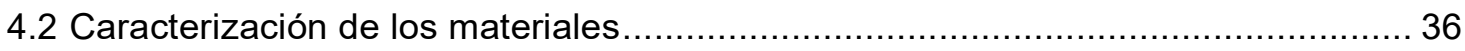

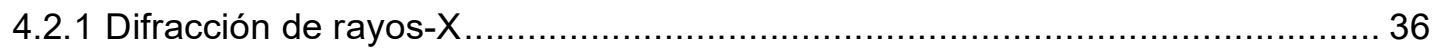

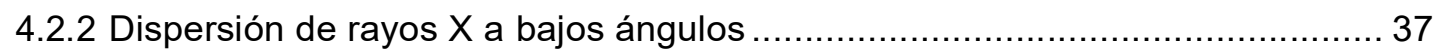

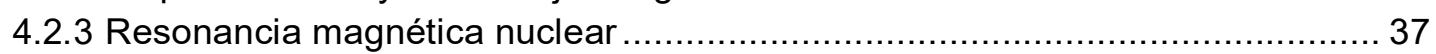

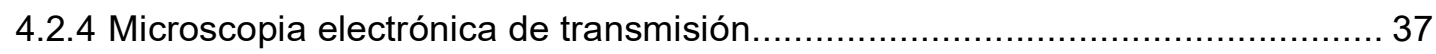

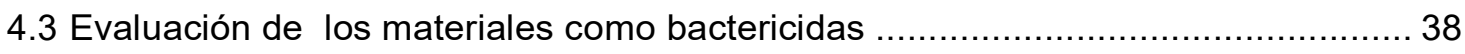

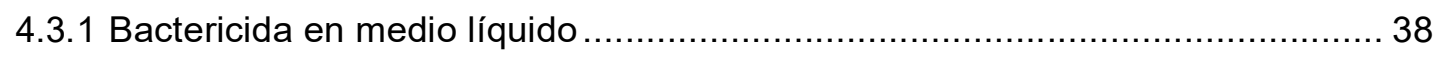

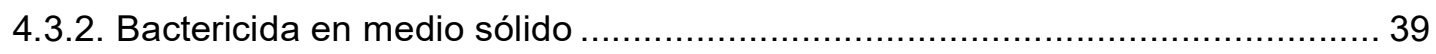

4.3.3 Crecimiento bacteriano en presencia de los materiales biocidas ................... 39

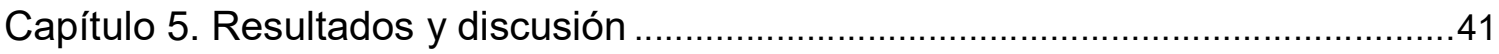

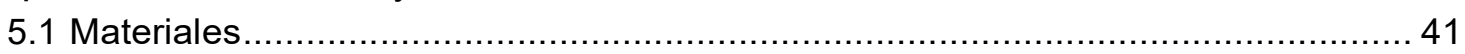

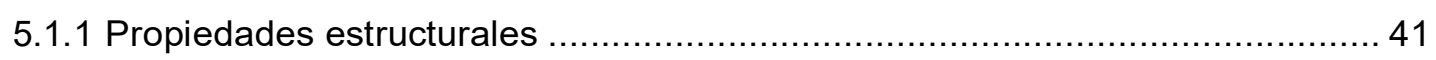

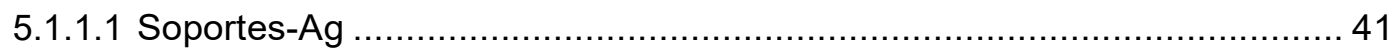

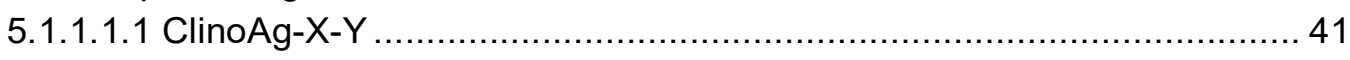

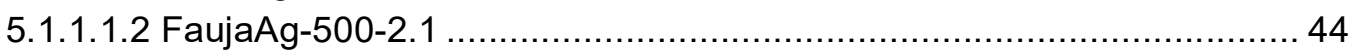

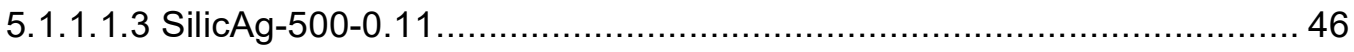

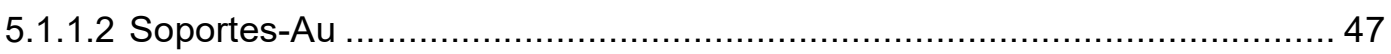

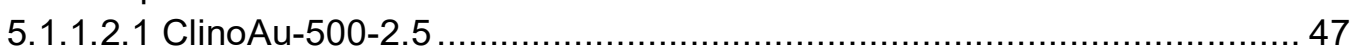

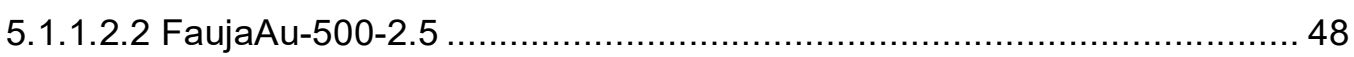

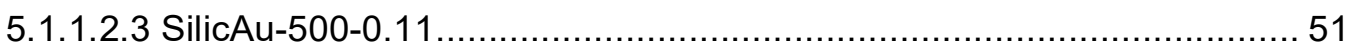

5.1.1.2.4 MordeAu-500-1.7 y MordeAu-500-2.9 ........................................ 51

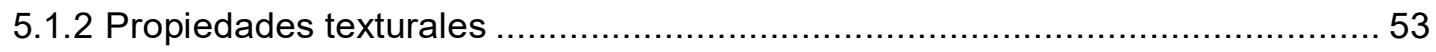

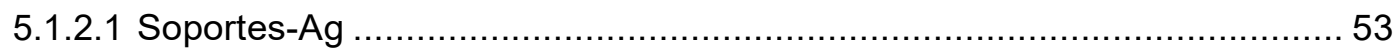

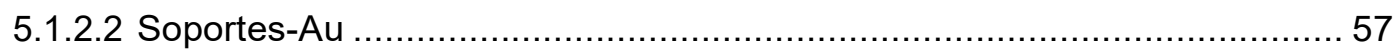

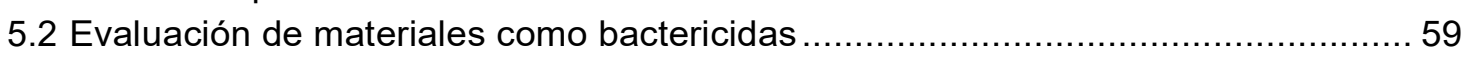

5.2.1 Ensayo de CMI para materiales soporte-Ag como biocida de E. Coli............... 59

5.2.2 Ensayo de CMI para materiales soporte-Ag como biocida de S. typhi ..............60 60

5.2.3 Ensayo de CMI para materiales soporte-Au como biocida de E. Coli............... 62

5.2.4 Ensayo de CMI para materiales soporte-Au como biocida de S. typhi ............. 63

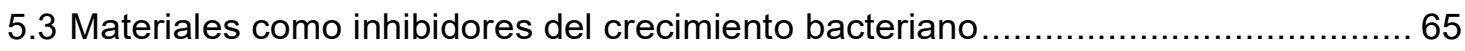

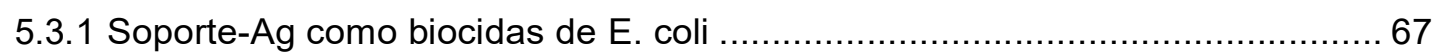


5.3.2 Soporte-Ag como biocidas de S. typh

Capítulo 6. Conclusiones y perspectivas

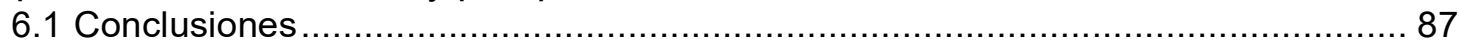

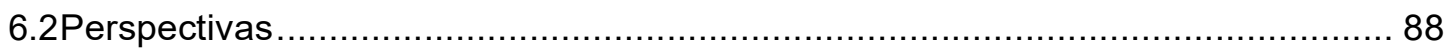

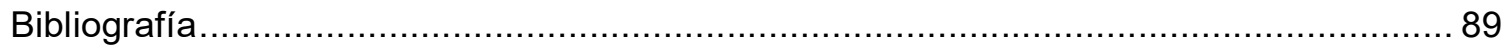

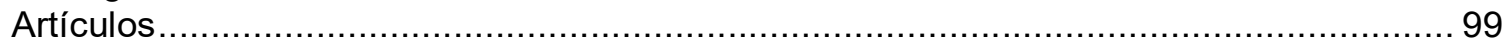




\section{Abreviaturas}

ADN: Ácido desoxirribonucleico.

APT: Activador tisular del plasminógeno.

PLP: Proteínas ligadoras de transpeptidasas y carboxipeptidasas.

LPS: Lipopolisacáridos.

CMI: Concentraciónmínima inhibitoria.

CMB: Concentraciónmínima bactericida.

NTU: Unidades Nefelométricas de turbidez. 


\section{Capítulo 1. Introducción}

La transmisión de patógenos por medio del agua continúa siendo un problema grave. Por ello, los agentes antimicrobianos son necesarios para inhibir la reproducción de patógenos. Una amplia variedad de agentes antimicrobianos se han empleado para este fin, cuya eficacia está determinada por varios factores físico-químicos. Muchos de ellos, sin embargo, son tóxicos, lo que los limita para su aplicación en algunos medios como agua potable, alimentos y productos textiles. En este sentido, la plata es un bactericida no tóxico para el ser humano, que puede reducir significativamente muchas infecciones bacterianas (Yin H., 1999).

La actividad antimicrobiana de especies de plata, los iones en particular, está bien documentada y se ha utilizado durante mucho tiempo para el tratamiento de heridas (Hugo W., 1995; Demling R., 2001). Por ejemplo, las soluciones de $\mathrm{AgNO}_{3}$ se han utilizado con frecuencia para el tratamiento de quemaduras. En la actualidad, la plata sigue siendo un agente común en el tratamiento de las heridas debido a que en muchos casos la prescripción de antibióticos está limitada (Gemmell C., 2006).

Además de los compuestos de plata, la medicina moderna ha empleado otros metales como el oro, que es un inhibidor del crecimiento del bacilo que causa la tuberculosis. En el tratamiento de varias formas de cáncer, se fijan partículas de oro a las células cancerígenas (Lapotko D., 2006). Posteriormente, con un rayo láser se calientan estas partículas hasta que se consigue quemar las células tumorales. Esto permite destruir sólo las células cancerígenas y salvar los tejidos sanos,lo que posibilitaría desmarcarse de las técnicas actuales, radioterapia y quimioterapia, que sí destruyen las zonas no afectadas por la enfermedad, con perniciosos efectos secundarios para el paciente.

Algunas sales inorgánicas de oro, conteniendo grupos sulfhidrilos (SH), tienen propiedades antibacterianas; estos compuestos pueden inhibir la actividad enzimática de los liposomas en los macrófagos. 
La actividad antimicrobiana de soluciones de oro se ha investigado muy poco, mientras que el efecto de la actividad antibacteriana del oro soportado en un material poroso no se ha reportado. No obstante, se espera que los cationes de oro $\mathrm{Au}^{\mathrm{n}+}$, de manera similar a la plata $\left(\mathrm{Ag}^{+}\right)$, sean atraídos electrostáticamente por las células y entonces se produzcan reacciones en la superficie celular, desalojando los iones $\mathrm{Ca}^{2+}$ y $\mathrm{Zn}^{2+}$. Sin embargo, en solución acuosa los iones $\left(\mathrm{Au}^{+}, \mathrm{Au}^{3+} \circ \mathrm{Ag}^{+}\right)$ pueden intercambiarse con otros iones del medio, disminuyendo así su disponibilidad para afectar a las bacterias. Así, las partículas metálicas $\mathrm{Au}^{0}$ y $\mathrm{Ag}^{0}$ son deseables y se espera sean igualmente letales para matar bacterias.

El área superficial de las partículas metálicas en contacto con las bacterias, está directamente relacionada con su eficiencia bactericida. Por lo tanto, el área superficial de las partículas de Ag y Au será de suma importancia.Por ejemplo, la alta superficie específica y alta proporción de átomos de la superficie de las partículas de plata da lugar a una gran actividad bactericida, si se compara con el metal de plata a granel (Chmielewska D., 2006). Además, los metales plata y oro, cuando se usan en cantidades razonables, no tienen efectos negativos en el cuerpo humano.

En este sentido, en el ámbito de la catálisis, a fin de maximizar la superficie activa los catalizadores están frecuentemente compuestos por un metal (fase activa) soportado en una estructura inorgánica. Por tanto, esta estrategia podría utilizarse para preparar partículas de plata y oro soportadas, capaz de inhibir el crecimiento de patógenos. Los iones de plata y oro soportados, pueden usarse para inhibir el crecimiento de patógenos, ya sea añadiéndolos directamente en agua o incorporadolos en varios materiales, por ejemplo textiles.

Teniendo en cuenta estas aplicaciones, se inició este trabajo con el objetivo de estudiar la eficiencia de plata y oro soportada en zeolitas como sistemas para evitar el desarrollo bacteriano. Se han seleccionado estos soportes ya que pueden variarse fácilmente sus propiedades físico-químicas. La plata y el oro soportados en zeolitas tipo silicalita, mordenita, faujasita y clipnotilolita se probaron como bactericidas de Escherichia coli(E. coli) ySalmonella typhi (S. typhi). 


\section{Capítulo 2. Antecedentes}

La contaminación microbiológica de las aguas de consumo humano impacta negativamente a la salud de la población. Los riesgos epidemiológicos, relacionados con el consumo de agua contaminada por microorganismos virulentos son causales del cólera, de las fiebres tifoideas o de la hepatitis vírica. Una contaminación microbiológica puede afectar a algunas personas o a comunidades enteras, dependiendo de la calidad o del tipo de microorganismo, su modo de transmisión, así como del perfil de las personas contaminadas. La contaminación microbiológica del agua ocurre por lo general a través de aguas residuales con heces de origen humano o animal (Anales de la real academia nacional de la medicina, 1975).

El riesgo de contraer una infección por microorganismos patógenos depende de su grado de invasión, de su dosis mínima infectante así como del nivel inmunológico del organismo huésped. Algunas bacterias patógenas pueden incluso multiplicarse en los alimentos y las bebidas, lo que aumenta los riesgos de infección. Debido a estas condiciones, en el caso de los microorganismospatógenosno existe un límite inferior tolerable; por lo que el agua destinada al consumo (alimentos y bebidas) y a la higiene personal no debe contener ningún agente patógeno para los seres humanos (NMX-AA-42-SCFI- 1987, 2000).

Las bacterias patogénicas, como S.typhiy E. coli, son de particular interés por ser transmisoras de enfermedades por alimentos; son causantes de enfermedades peligrosas, como la salmonelosis en el caso de la Salmonella y el síndrome urémico hemolítico por E. coli, ambas con consecuencias graves y permanentes para el ser humano. 
Capítulo 2

\subsection{Bacterias}

Las bacterias constituyen un grupo heterogéneo de organismos desde el punto de vista morfológico. Las bacterias son procariotas, que a diferencia de las células eucariotas no tienen un núcleo definido; contienen un solo cromosoma, formado por un ADN (ácido desoxirribonucleico) circular en doble helicoide, sin proteínas asociadas; carecen de microtúbulos y estructuras relacionadas con el retículo endoplásmico como el aparato de Golgi y mitocondrias (Pumarola A., 1987).

Las partes principales de las bacterias son: pared celular, compuesta por una serie de ácidos orgánicos que la propia bacteria sintetiza; membrana plasmática, formada por lípidos y proteínas, es la responsable de la permeabilidad de la célula, respiración y transporte de electrones, por lo que participa en la degradación biológica de los nutrientes; y citoplasma, formado por un complejo de biomoléculas, enzimas y ribosomas, participa en la degradación primaria de los nutrientes por glucolisis (Figura 2.1). En el citoplasma se halla un ADN circular y numerosos ribosomas. La pared bacteriana da rigidez y forma a la célula; su estructura molecular básica es el peptidoglucano. La pared puede contener algunos otros componentes, además del peptidoglucano, como los lipopolisacáridos en las bacterias Gramnegativas y los ácidos teiónicos en las bacterias Grampositivas (Macarulla J., 1994; Pumarola A., 1987).

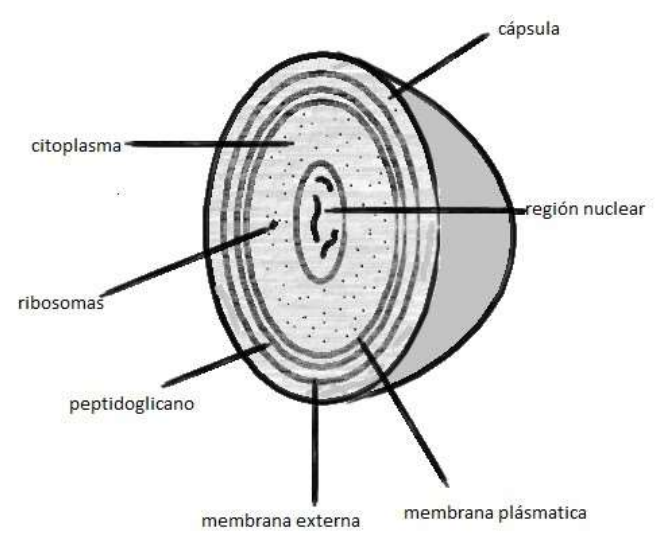

Figura 2.1. Esquema estructural de una bacteria 


\subsubsection{Pared celular de bacterias Grampositivas y Gramnegativas}

La pared celular bacteriana desempeña diversas funciones, protege a las estructuras celulares internas de la acción de las fuerzas osmóticas y físicas que pueden existir en el entorno cambiante de una bacteria, da rigidez a la estructura celular, provee un medio de transporte para la circulación y distribución de agua, de minerales y de nutrientes; contiene moléculas que regulan el crecimiento celular (Struther J., 2005).

Las bacterias Grampositivas tienen una pared celular compuesta principalmente (90\%) de cadenas de peptidoglucano unidas a ácidos teiónicos. Una de las funciones importantes de los ácidos teiónicos, es que al unirse a cationes

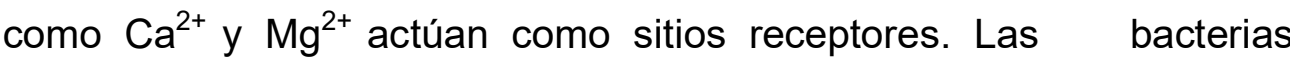
Grampositivas mantienen un $\mathrm{pH}$ relativamente bajo en su pared, impidiendo la degradación de la pared celular por una acción de enzimas endógenas en su etapa de desarrollo. Son capaces de asimilar protones y cuentan con un carbohidrato semejante a la glucosa. Cuando las concentraciones de fosfato en el medio son bajas, el ácido teiónico de su pared puede sustituirse por ácidos teicurónicos, lo que le permite a la célula seguir produciendo adenin trifosfato (ATP) y otros componentes celulares. Los ácidos teicurónicos son cadenas de polisacáridos compuestas por ácidos urónicos y $\mathrm{N}$-acetilglucosamina, y junto con los polisacáridos anionicos se encargan de mantener la acidez en la pared celular (Ronald M., 1995).

En las bacterias Gramnegativas el peptidoglucano se localiza entre la membrana citoplasmática y la bicapa lipídica externa. Su pared externa contiene lipopolisacáridos (LPS) compuesta por ácidos grasos y cadenas de oligosacáridos y polisacáridos. En su conjunto, forman una capa protectora hidrófila en torno a la célula bacteriana, por lo que se cree que esta lipoproteína le otorga mayor resistencia y estabilidad a la membrana externa (Struther J., 2005).

El peptidoglucano establece enlaces cruzados a través de cadenas laterales constituidas por péptidos cortos. Estas cadenas laterales son esenciales 
para la estabilidad del peptidoglucano y de la propia pared celular. Los enlaces cruzados se establecen mediante transpeptidasas y carboxipeptidasas (PLP), que son proteínas ancladas en la membrana citoplasmática (figura 2.2).

La pared celular de las bacterias Gramnegativas es más compleja que la de las Grampositivas. La bicapa lipídica externa presenta proteínas (como las adhesinas) y flagelos que atraviesan esta membrana (figura 2.3). Los LPS se construyen a partir de un lípido (lípido A) unido a la porción hidrofóbica de la membrana externa; el lípido A se compone a su vez de $\mathrm{N}$-acetilglucosamina que es un disacárido unido por medio de grupos ester a B-hidroximirística. La Bhidroximirística se construye a partir de grupos específicos de ácidos grasos, ácidos capróicos y ácidos láuricos (Macarulla J., 1994; Klein D. et al, 1999).

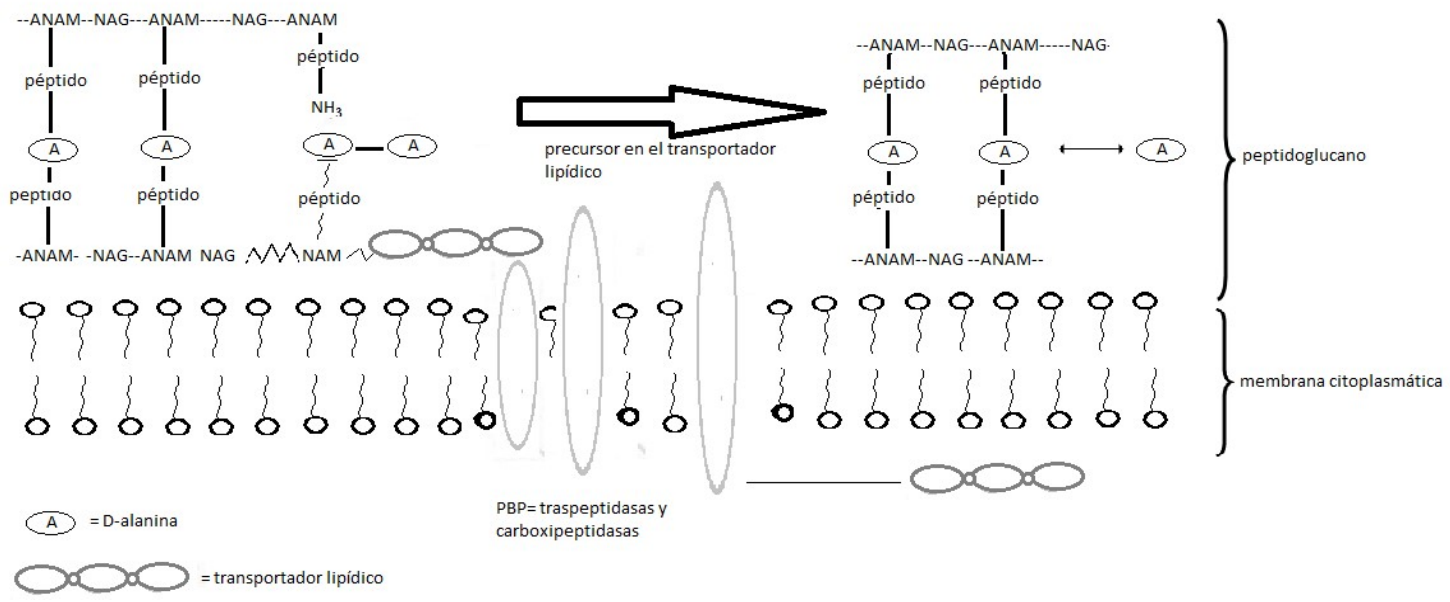

Figura 2.2. Peptidoglucano constituido por unidades repetidas de N-acetilglucosamina (NAG) y de ácido $\mathrm{N}$-acetilmurámico (ANAM) con enlaces cruzados establecidos mediante cadenas peptídicas laterales. Las PBP son responsables de los enlaces cruzados entre dichas cadenas.

La membrana externa de las bacterias Gramnegativas funciona como filtro de substancias, seleccionando su entrada a la célula en función de su tamaño y peso. Esta selección la realizan las porinas, las cuales suelen encontrarse agrupadas en triadas y cuentan con un canal iónico que permite el paso de moléculas hidratadas a lo largo de la membrana citoplasmática (Ronald M., 1995). 


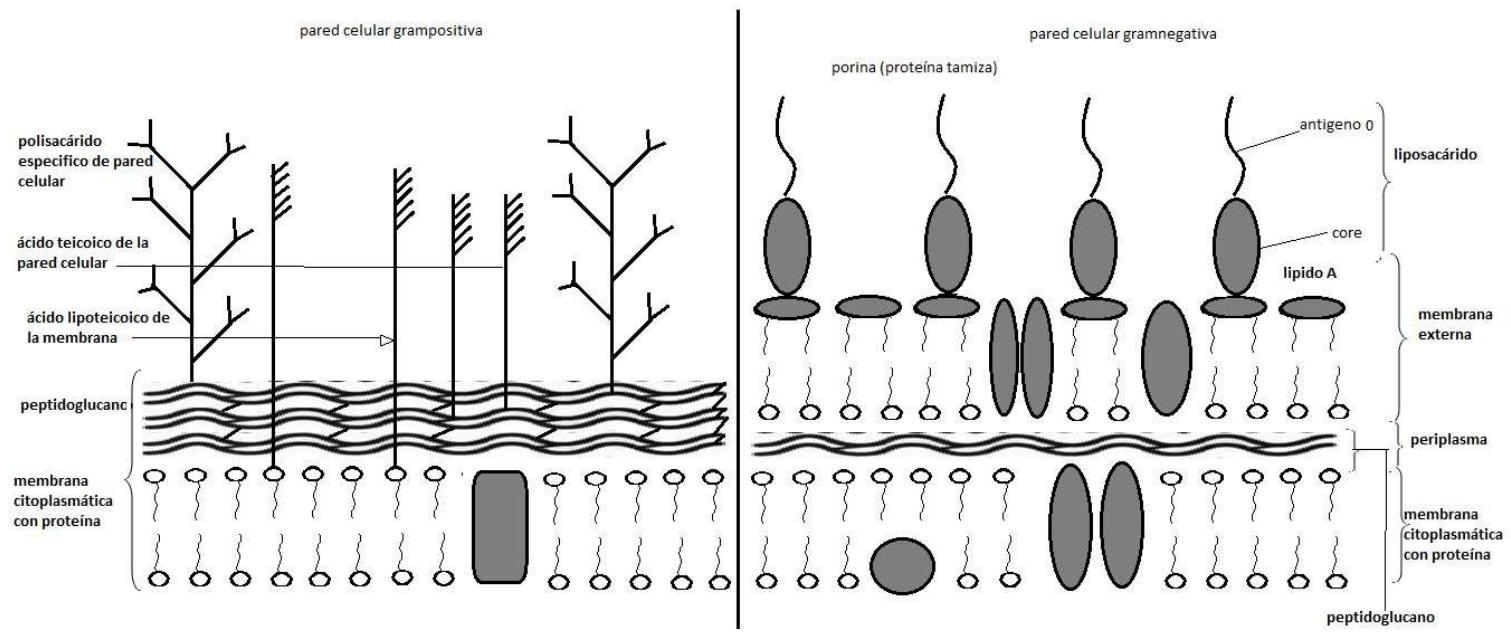

Figura 2.3. Corte transversal de la pared celular de una bacteria Grampositiva y una bacteria Gramnegativa.

\subsubsection{Plásmidos}

Los plásmidos son moléculas de ADN extracromosómico, formando estructuras secundarias tipo doble hélice, dispersas en el citoplasma. Los plásmidos transportan genes que codifican proteínas que modifican o destruir a los antibióticos. Los plásmidos se replican siguiendo el mismo mecanismo que el ADN cromosomático y, generalmente, lo hacen una vez por cada ciclo celular bacteriano, de modo que las bacterias hijas conservan el mismo número de plásmidos que la progenitora. Los plásmidos también pueden invadir el citoplasma de otras células, incluso de distintas especie, y transmitirse a la nueva progenie (Macarulla J., 1994; Klein D., 1999; Pumarola A., 1987). 


\subsubsection{Transmisión genética de las bacterias}

El ADN cromosómatico puede transferirse entre las bacterias a través de virus bacterianos (bacteriófagos) o bien por mecanismos de transformación o de conjugación. Muchas bacterias contienen plásmidos extracromosómicos cuya cantidad por célula puede ser de una o más copias. Cuando hay dos o más copias por célula, cada célula hija hereda generalmente un plásmido tras la división celular (Figura 2.4a). Los plásmidos también pueden ser transferidos desde una célula $\mathrm{F}+$ (donadora) a una célula F- (receptora), mediante el proceso de conjugación. En este proceso, la célula $\mathrm{F}+$ sigue siendo $\mathrm{F}+$ (Macarulla J., 1994). Así, los plásmidos pueden transmitirse verticalmente de una generación a otra a través de la división celular, u horizontalmente a través del proceso de conjugación (Figura 2.4b) (Struther J., 2005). Para ello es necesaria una fibra sexual, es decir, un tubo proteico simple.

a)

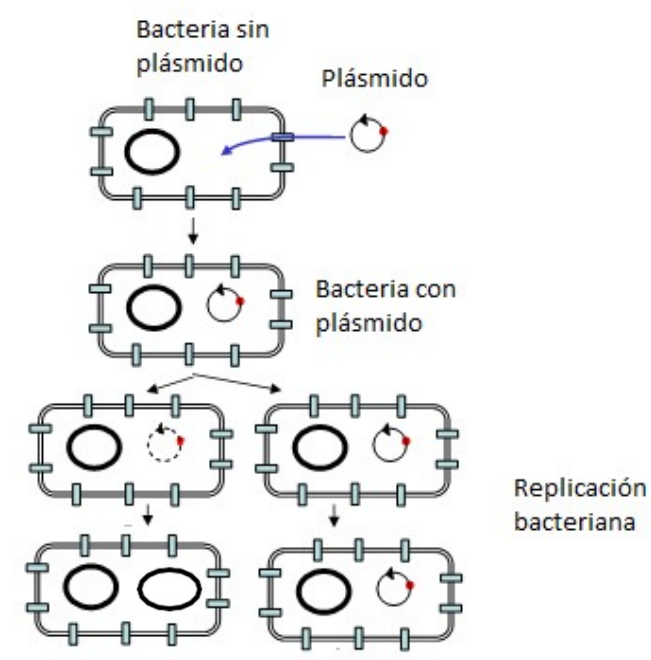

b)

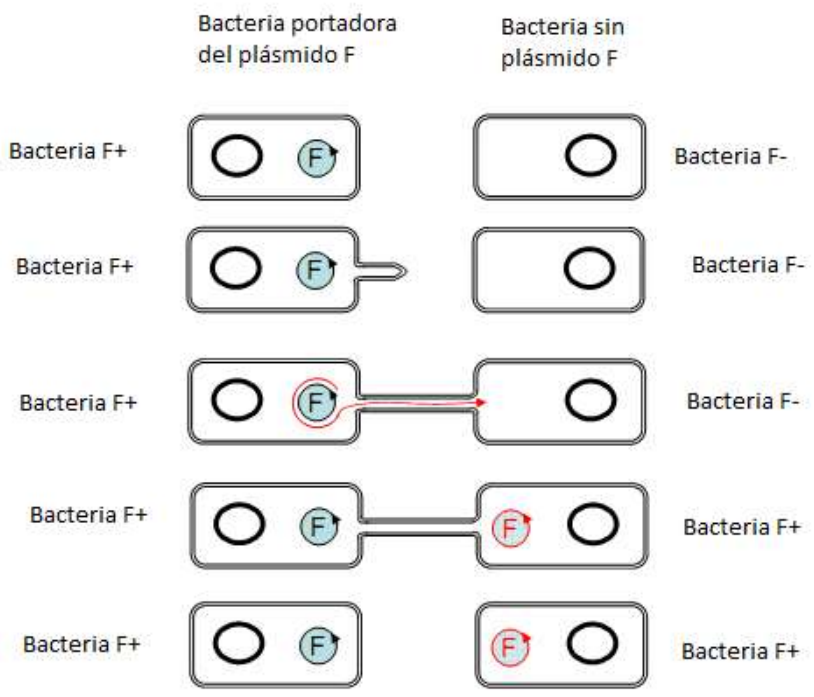

Figura 2.4. Transferencia de material genético de una célula a otra. (a) una o más copias por cada célula; (b) proceso de conjugación. 


\subsubsection{S. typhi y E. coli}

El grupo de bacilos Gramnegativos incluye diferentes familias y géneros. Muchos de ellos son ubicuos, encontrándose muy difundidos entre los animales y la naturaleza, como es el caso de $S$. typhi y E. coli que causan enfermedades en el hombre y los animales. Estas bacterias causan la mayoría de las hospitalizaciones relacionadas con enfermedades transmitidas por alimentos. Mientras una nueva cepa letal de E. coli acaparaba los titulares en Europa en el 2011, para los estadounidenses la salmonella sigue siendo la mayor amenaza para la salud transmitida por los alimentos (FSIS, 2011).

La fiebre tifoidea es una infección aguda y generalizada del sistema retículo endotelial causada por S. typhi. Se estima que la padecen más de 16 millones de personas en todo el mundo cada año (World Health Organization, 1996). tratamiento oportuno con agentes antimicrobianos apropiados es importante para reducir la mortalidad de las infecciones extraintestinales por S. typhi (Edelman R., 1986). Lamentablemente, la Salmonella ha desarrollado resistencia a los agentes antimicrobianos, como la ampicilina, el cloranfenicol, y combinaciones de trimetoprim-sulfonamidas (Rowe B. et al, 1997). En muchos países se usa el ácido nalidíxico (quinonas) como antibiótico para enfermedades causadas por la salmonella, pero la salmonella también ha mostrado resistencia a estos tratamientos.

Entrelos agentes patógenos entéricos, la $E$. coli es una de las especies bacterianas más estudiada. La $E$. colise ha asociado con las enfermedades gastrointestinales; este microoorganismopresentadiferentes factoresde virulencia(por ejemplo,adhesinas, invasinas, y toxinas) que son responsables deuna amplia gama de enfermedades diarreicas(Nataro J., 1998). Las E. coli diarreagénicas se clasifican en seis patotipos: $E$. coli enteropatógena (EPEC), $E$. coli enterotoxigénica (ETEC), E. coli enterohemorrágica (EHEC), E. coli enteroinvasiva (EIEC), E. coli difusamente adherente (DAEC), y E. coli enteroagregativa (ECEA) (Nataro J., 2005). La CEEA se considera la principal causa de brotes de diarrea en Europa, el Reino Unido, Suiza y Japón. La CEEA y 
ETEC es causal de diarrea bacteriana y es común en los países en desarrollo (Ruttler M. et al, 2002; Nataro J. et al, 2006).

Los antimicrobianos constituyen la base fundamental del tratamiento de las enfermedades infecciosas, uno de los problemas más frecuentes y causante de la mayor morbimortalidad en cualquier especialidad médica.

Existen diferentes mecanismos para destruir microorganismos, como someterlos a condiciones ambientales como: la desecación, ebullición, rayos ultravioletas, ultrasonido, etc., estosmecanismosse llaman de esterilización, al igual que otras sustancias antimicrobianas (como los antisépticos) no pueden aplicarseen el tratamiento de agua potable o alimentos. Entonces, esnecesario introducir otras sustancias químicas (naturales o sintéticas) que destruyan al germen, sin alterar en forma importante las células, evitando efectos colaterales, debiendo destruir preferentemente a varios gérmenes a la vez y evitar que se defiendan creando mecanismos de resistencia.

\subsection{Interacción bacteria-metal}

La plata y otros metales pesados pueden llegar a ser muy efectivos en la inhibición del crecimiento bacteriano y son preferibles a otros agentes antibacterianos, ya que no representan un riesgo alto ni cambian las características físicas del agua, minimizando la formación de subproductos durante el proceso de desinfección (Tortora G., 2007).

Para llevar a cabo sus funciones metabólicas, los microorganismos requieren de la presencia de algunos iones inorgánicos esenciales, como los iones de los metales calcio, magnesio, sodio, potasio y manganeso. Algunos metales presentes en el ambiente son intrínsecamente tóxicos y carecen de actividad biológica (como los metales pesados: plomo, mercurio, cadmio, cobre, plata, etc.), o bien son esenciales pero presentan toxicidad cuando se encuentran en concentraciones relativamente elevadas, es el caso de cobre, zinc, cobalto, níquel, etc. aunque los mecanismos de toxicidad de los metales son diversos, los sistemas más comunes involucran una interferencia con el transporte y la función 
de los iones fisiológicos esenciales, o la integración como las macromoléculas celulares tales como las enzimas y los ácidos nucleicos.

Los iones que interactúan con las células bacterianas pueden clasificarse en tres grupos:

a) Iones esenciales. Se refiere a aquellos iones que son indispensables para desarrollo bacteriano, como $\mathrm{Mg}^{2+}, \mathrm{K}^{+}, \mathrm{PO}_{4}{ }^{3-}, \mathrm{SO}_{4}{ }^{2-}$, que son considerados como nutrientes; en este grupo están también aquellos que la célula requiere en menores cantidades como $\mathrm{Mn}^{2+}, \mathrm{Fe}^{2+}, \mathrm{Zn}^{2+}, \mathrm{Ni}^{2+}, \mathrm{Cu}^{2+}$ y $\mathrm{Co}^{2+}$, que son considerados como micronutrientes o minerales traza.

b) lones no esenciales. Son iones que, a pesar de su abundancia natural, no son indispensables para el metabolismo bacteriano; entre ellos están $\mathrm{Na}^{+}$y $\mathrm{Cl}^{-}$.Las bacterias los utilizan en procesos regulatorios o en funciones de las proteínas accesorias de las células (filamentos del citoplasma).

c) lones tóxicos. Son iones que, dada su interacción con las macromoléculas celulares, son altamente nocivos para el desarrollo bacteriano; incluyen los iones: $\mathrm{Hg}^{2+}, \mathrm{AsO}_{4}{ }^{3-}, \mathrm{AsO}_{2}{ }^{-}, \mathrm{Cd}^{2+}, \mathrm{Ag}^{+}, \mathrm{Pb}^{2+}, \mathrm{CrO}_{4}{ }^{2-}, \mathrm{TeO}_{3}{ }^{2-}, \mathrm{SbO}^{+}, \mathrm{BiO}^{+}$y otros (Silver S., 1983). Las células bacterianas han elaborado mecanismos de resistencia a iones tóxicos; estos mecanismos son muy específicos, codificados por genes que se encuentran en plásmidos o en transposones (Silver S. et al., 1989).

Los principales mecanismos mediante los cuales las bacterias interactúan con los metales tóxicos son (Cervantes C., 1992): a) la precipitación extracelular de los iones tóxicos por sustancia excretadas por las bacterias; b) la unión de los cationes metálicos con las cubiertas celulares, por lo general con las cargas negativas de los constituyentes de la pared celular; c) la acumulación intracelular mediante la unión de los metales a componentes citoplásmaticos; d) las reacciones redox que convierten a algunos iones en especies químicas menos tóxicas; y, e) los sistemas de expulsión de la membrana que impiden la acumulación de los iones nocivos. 
En las bacterias, los genes se hallan agrupados en los cromosomas. La reproducción de las bacterias puede inhibirse por los iones de los metales pesados tóxicos, pero, a la vez, las bacterias pueden desarrollar resistencia al efecto tóxico del metal. Los genes que confieren esta resistencia a los metales pesados generalmente se localizan en los plásmidos, fuera del cromosoma bacteriano. Las estrategias bacterianas más eficientes para resistir a los metales tóxicos, son probablemente las que provocan la expulsión del metal (en su forma de ion) desde el interior de las bacterias hacia el medio externo; de esta forma disminuye la concentración del ion dentro de la célula y, por lo tanto, se reduce su toxicidad (Cervantes C., 1992).

Varios metales pesados, como la plata, el mercurio y el cobre, son germicidas o antisépticos. Cantidades muy pequeñas de metales pesados, en especial de plata y cobre, son capaces de ejercer actividad antimicrobiana, lo que se conoce como acción oligodinámica. Este efecto se produce por la acción de los iones de los metales pesados sobre los microorganismos. Cuando estos iones interaccionan con los grupos sulfhidrilo existentes en las proteínas, así como en el ADN, se produce su desnaturalización por la inhibición de los procesos respiratorios (Tortora G., 2007).

La plata es tóxica para las bacterias a concentraciones tan bajas como $0.5 \mu \mathrm{M}$ (Tuovinen O. et al, 1985).

Los niveles de tolerancia a iones metálicos dependen de la cepa y del estado fisiológico del organismo, de su historia previa a la exposición del metal tóxico y de las condiciones ambientales (Cooper R., 2004). La efectividad de los agentes antimicrobianos depende de la especie de bacteria. Las paredes de las células Grampositivas contienen de 3 a 20 veces más peptidoglucano que una especie Gramnegativa,siendo las paredes Grampositivas capaces de asimilar protones y cuentan con un carbohidrato semejante a la glucosa. Debido a que los peptidoglucanos pueden asimilar protones, las bacterias Grampositivas son generalmente menos sensibles a agentes antimicrobianos que contienen iones de metales pesados que las especies Gramnegativas (Kawahara K., 2000). 
Capítulo 2

\subsection{Interacciones plata-bacterias}

\subsubsection{Plata iónica como bactericida}

La plata se usa actualmente en filtros de carbón activado para purificar el agua o evitar su contaminación. Las sales de plata poseen efectos bactericidas y fungicidas, además son efectivas como agente antiviral. Tienen afinidad por los grupos sulfhidrilos de los sistemas enzimáticos de la pared celular bacteriana, a través de la cual interfieren en la transferencia de energía transmembrana y en el transporte de electrones (Murray R., 2010). Las sales de plata,como el nitrato,se usan como antiséptico y astringente dermatológico; el sulfato de plata, por su parte, se usa en eltratamiento de quemaduras y heridas abiertas (Landeen K., 1989). La plata iónica ha demostrado una actividad antimicrobiana muy alta frente a bacterias Gramnegativas y moderada frente a bacterias Grampositivas. La sulfadiazina de plata, un compuesto polimérico insoluble que libera plata lentamente, actúa como bactericida a la mayoría de las bacterias Grampositivas, Gramnegativas y levaduras, por lo que se aplica en forma de crema como fungicida y antimicrobiano en quemaduras severas (Sadler P., 1991).

De manera general, las sales de plata tienen como sitio de acción los constituyentes citoplasmáticos y la interacción con grupos sulfhidrilo y amino, mediante mecanismos de coagulación general, ataque a los ácidos nucleicos, y a los ribosomas (Maillard J., 2002).

Laplata coloidal (suspensión de partículas de plata metálica)y la plata iónica (disolución de iones de plata)tienen poder bactericida, pero su comportamiento y efectos como inhibidor de bacterias son muy distintos. La plata coloidal inactiva las enzimas de las células bacterianas y hongos que usan oxígeno para su metabolismo, aunque en tiempos muy variables y dependientes de la temperatura. A temperaturas inferiores a $10{ }^{\circ} \mathrm{C}$ se requieren tiempos muy largos, lo que hace difícil determinar el poder germicida con exactitud. La plata coloidal no elimina a los virus, pero es eficaz para destruir diversas bacterias (E. Coli, Staphyloccus Aureus, Pseudomonas, Aspergilus, fecales). El efecto de la actividad bactericida de la plata coloidal no se puede generalizar a una amplia 
variedad de microorganismos y tampoco se puede utilizar una dosis única. Se ha demostrado que el efecto bactericida de la plata coloidal es reducido cuando se le compara con el efecto de la cal o hipoclorito de sodio (Muñoz R., 1995) y que tiende a ser eficiente en la reducción de cargas bacterianas de coliformes (García J., 2004).

Los iones de plata se introducen en el interior de la célula a través de transportadores de metales presentes en su membrana, compitiendo con ellos por los lugares de captación. Actúan interfiriendo en la permeabilidad gaseosa de la membrana y, una vez en el interior de la célula, alteran su sistema enzimático, inhibiendo su metabolismo y producción de energía y modificando su material genético. El resultado es que el microorganismo pierde rápidamente toda capacidad de crecer y reproducirse.

Los iones de plata eliminan a la mayoría de las bacterias, hongos, virus y protozoos, aunque son menos activos frente a las esporas (Russell A., 2003), tienen afinidad por el $A D N$ tanto bacteriano como eucariótico, donde interactúan preferentemente con las bases nitrogenadas más que con los grupos fosfato (McDonell G., 1999).

En altas concentraciones, los iones $\mathrm{Ag}^{+}$reaccionan con los grupos donadores de electrones, e inhiben la mayoría de las reacciones enzimáticas. El intercambio de sodio $\left(\mathrm{Na}^{+}\right)$en la enzima oxidoreductasa ubiquinona ha sido reconocido como uno de los primeros blancos de los iones de plata.La adición de concentraciones micromolares de $\mathrm{Ag}^{+}$fuera de la membrana induce un colapso total de una amplia variedad de bacterias (Dibrov P.,2002).

Los iones de plata actúan sobre los microorganismos a pH cercanos a 7, ya seaen el exterior o interior de la célula. En el exterior de la célula, los cationes de plata son atraídos electrostáticamente por la carga negativa de la membrana, en la que causan alteraciones drásticas en la pared celular y en la membrana citoplásmatica (Goodman A., 1982). En el interior de la célula, la inactivación se produce por su interacción con las proteínas y en los ácidos nucleicos. La interacción de la plata con grupos sulfhídricos y las enzimas es uno de los 
orígenes de su capacidad biocida. Al parecer puede romper los enlaces $\mathrm{N}-\mathrm{H}$ de las aminas purinas y pirimidinas causando la desnaturalización, evitando de este modo la replicación.

La forma soluble de la plata es la más tóxica para las bacterias. Sin embargo, tanto el medio ambiente como los medios de cultivo pueden inducir la formación de complejos con $\mathrm{SO}_{4}{ }^{2-}, \mathrm{PO}_{4}{ }^{3-} \mathrm{O} \mathrm{Cl}^{-}$, disminuyendo así la forma activa que inhibe el crecimiento bacteriano. La plata iónica mata células bacterianas sensibles por efectos en la superficie de la membrana celular, inhibiendo la respiración celular y desacoplando la síntesis de ATP (Belliveau B., 1987).

Se ha reportado que la eficiencia del material bactericida depende del tipo de microorganismo. En estudios con E. coli (Gramnegativa) y Staphylococcus aureus (Grampositiva), se reportó que la elevada eficiencia bactericida de las partículas de plata para $E$. coli se debe a la diferencia de las estructuras de la pared de la célula en microorganismo Gramnegativo y Grampositivo (Sondi I., 2004). Sin embargo, no hay suficiente evidencia para soportar dichas conclusiones debido a que la mayoría de las investigaciones sobre el efecto bactericida de nanopartículas sólo se ha hecho en un número muy limitado de cepas (Sondi I., 2004; Cho K., 2005).

\subsubsection{Plata como antibiótico}

El incremento en el número de cepas bacterianas resistentes a los antibióticos ha promovido el interés del uso de plata como agente antibacteriano (Stobie N., 2008).

En los hospitales, uno de los compuestos que se usa con frecuencia es el nitrato de plata en soluciones diluidas, aplicándolo, por ejemplo, en los ojos de recién nacidos para evitar posibles infecciones (Rai M., 2009).

El uso de apósitos es muy útil cuando las bacterias resistentes a los antibióticos representan un problema. Una combinación de plata con sulfadiazida, se utiliza como crema tópica para uso en quemaduras graves (Tortora G., 2007). 
Los catéteres recubiertos con sulfadiazina de plata, proporcionan una protección contra el crecimiento de una amplia gama de microorganismos Grampositivos y Gramnegativos. Este recubrimiento no parece causar la aparición de resistencia bacteriana (Esteban A., 2005). El uso de manguitos de colágeno impregnados en plata iónica disminuye la carga microbiana en el lugar de aplicación, protegiendo mediante dos vías la actividad antimicrobiana y es una barrera física que dificulta la migración de las bacterias (Torres M., 2002).

\subsubsection{Mecanismos de la plata como bactericida}

Aunque el mecanismo de la actividad antimicrobiana de la plata no se conoce, se ha propuesto que en disolución acuosa interfiere en el transporte electrónico, en la unión al ADN cromosomatico, e interacciona con la membrana celular y con el grupo tiol de ciertas enzimas, inhibiéndolas (Thurman R., 1989).Se asumeque la plata tiene efecto bactericida por los cambios morfológicos y estructurales observados en la bacteria después de exponerse a sus compuestos. La plata reacciona con los grupos azufrados de las membranas de las enzimas, provocando que la membrana pierda permeabilidad; la bacteria no es capaz,entonces, de efectuar procesos de respiración y muere (Feng Q., 2000).

La actividad antimicrobiana de la plata depende de los iones de plata, que se unen fuertemente a grupos donadores de electrones en moléculas biológicas que contiene azufre, oxígeno o nitrógeno (Damm C., 2008). La formación de un complejo entre iones plata y proteínas puede interferir en el metabolismo de las células bacterianas y sus funciones, como permeabilidad y respiración (Panácek A., 2006). Ambos efectos dan camino a la destrucción de la célula. Además, los iones de plata pueden interactuar con el ADN de la bacteria, impidiendo la reproducción de la célula (Damm C., 2008).

Elmecanismo probable de la plata como bactericida puede ser el siguiente: Los iones de plata $\left(\mathrm{Ag}^{+}\right)$en contactocon las bacteriaspenetran la membrana celular,destruyendo la proteínade la bacteriasuspendiendo lasíntesisdel ADN bacteriano.Finalmente, cuando la plata iónica interactúa con los grupossulfihidrilos 
(-SH) de la enzima de los microorganismos, se forma un enlace S-Ag (Ecuación 2.1), bloqueando la actividad enzimática e impidiendo su respiración, provocando la muerte del microorganismo (Yan J., 2005). Las bacterias no pueden propagarsemás.

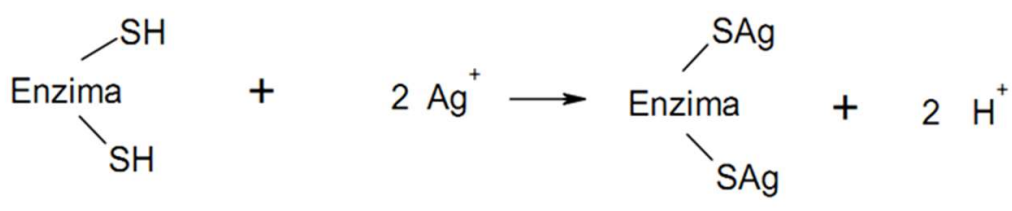

Ecuación 2.1

de los antibióticos farmacéuticos, las partículas de plata no destruyen a las enzimas benéficas de las células de tejido, pues son radicalmente diferentes de las enzimas de los organismos unicelulares más primitivos. Así, las partículas de plata son absolutamente seguras para losseres humanos, animales y plantas (Charles J., 2006).

\subsection{Oro iónico como bactericida}

El descubrimiento de Robert Koch sobre el complejo de oro con cianuro, $\mathrm{K}\left[\mathrm{Au}(\mathrm{CN})_{2}\right]$, y sus propiedades bactericidas contra el bacilo de la tuberculosis, dio origen a las aplicaciones medicinales de complejos metálicos del oro (Sigler J., 1972).

La creencia de que la artritis reumatoide era provocada por el bacilo de la tuberculosis condujo a la utilización de complejos de oro en el tratamiento de esta enfermedad. Estos complejos pronto se mostraron ineficaces en el tratamiento de la tuberculosis, pero comprobaron ser efectivos contra la artritis reumatoide (Ward J., 1983; Garry G., 1994).

Los primeros compuestos de oro $\left(\mathrm{Au}^{+}\right)$que se utilizaron para el tratamiento de la artritis reumatoide fueron derivados de tiolato; por ejemplo el aurotiomalato de sodio, la aurotioglucosa y el auranofin, este último puede suministrarse por vía oral (Fricker S., 1996).

Algunos tiolatos de oro $\left(\mathrm{Au}^{+}\right)$se emplean como antiinflamatorios en el tratamiento de la artritis reumatoide y otras enfermedades reumáticas, así como 
en enfermedades de la piel como el lupus. Las sales de oro de uso clínico son compuestos en donde el metal está unido a un sulfuro, lo que le confiere propiedades hidrofílicas. La alta afinidad del $\mathrm{Au}^{+}$por el sulfuro parece inhibir la actividad de varios sistemas enzimáticos, especialmente los que poseen grupos sulfhidrilos (Wright V., 1984).

Los compuestos de oro que se utilizan en tratamientos clínicos son derivados de $\mathrm{Au}^{+}$y contienen ligandos tiolato débiles que se intercambian con los ligandos biológicos. No se conoce el mecanismo de acción de estos compuestos; sin embargo, la gran afinidad que tienen los complejos de oro $\left(\mathrm{Au}^{+}\right)$para coordinarse con ligandos de azufre sugiere que la primera etapa sería el desplazamiento del ligando tiolato del derivado de oro y la formación de un nuevo complejo con una proteína que contenga átomos de azufre (Day R., 2005).

Existen distintas hipótesis para explicar el mecanismo bioquímico de acción de los compuestos de oro en las zonas inflamadas. Una de ellas propone que el oro puede inhibir la proliferación de las células T y modular el sistema inmune, modificar la permeabilidad de la membrana mitocondrial, inhibir la osteoclastia y otra serie de citoquinas claves en la inflamación, así como la actividad de la captesina implicada en la inflamación y destrucción de las articulaciones (Weidauer E., 2007). Otra de ellas sugiere que los compuestos con oro pueden inhibir la actividad enzimática de los liposomas en los macrófagos. Estos efectos celulares pueden deberse a la alta afinidad del oro por el azufre, lo que causa inhibición de los sistemas sulfhidrílicos (Martin A., 2006).

Está documentado que algunos complejos de $\mathrm{Au}^{+}$interaccionan con el ADN cromosómico, pero además deben interaccionar con otros sitios celulares, la mitocondria parece ser la mejor candidata (McKeage M., 2002).

Los derivados de oro como el $\mathrm{Au}(\mathrm{SCN})\left(\mathrm{PMe}_{3}\right)$ y $\left[\mathrm{Au}(1,2,4 \text {-triazol })\left(\mathrm{PPh}_{3}\right)\right]_{2}$ presentan buena actividad antimicrobiana contra bacterias Grampositivas, pero no frente a Gramnegativas. La actividad antimicrobiana de los complejos de oro frente a bacterias Grampositivas no sólo está relacionada con el metal, sino también con los ligandos fosfina y aminotiol a los que está unido el oro (Novelli F., 1999). La 
Capítulo 2

facilidad de estos ligandos para acoplarse con entornos AuSP y AuNP (formación de un enlace Au-S o Au-N y retención del enlace Au-P), por ligandos biológicos, determina la actividad microbiana del $\mathrm{Au}^{+}$(Nomiya K., 2003).

\subsection{Partículas metálicas de plata y oro como bactericidas}

La plata iónica interacciona electrostáticamente con la membrana de la célula, desalojando los iones de calcio y zinc por intercambio iónico. Sin embargo, los iones de plata interaccionan con los iones del medio externo a la célula, disminuyendo la concentración de iones de plata para interactuar con la membrana de la célula. Entonces, la plata metálica parcialmente cargada $\left(\mathrm{Ag}^{\delta+}\right)$, puede proponerse como bactericida. En este caso no se tendría el problema de disminución en la concentración por intercambio iónico con el medio externo a la célula. Además de la plata también existen otras partículas metálicas que pueden interactuar con la membrana de la célula, por ejemplo oro, que es también un metal noble que puede seguir el mismo mecanismo que las partículas de plata sobre todo las partículas a escala nanométrica, como ya se ha mostrado en catálisis(Huang et al., 2007).

\subsection{Partículas de Ag y Au soportadas como bactericidas}

El objetivo de utilizar un soporte para dispersar el metal es maximizar la superficie activa. Los soportes, sin embargo, son muchos y muy diferentes con respecto a sus propiedades físico-químicas, que a su vez determinan las propiedades de los metales soportados. Las partículas de plata u orosoportadas pueden usarse para inhibir el crecimiento de patógenos, ya sea añadiéndolas directamente en agua o incorporándolas en varios materiales. Teniendo en cuenta estas aplicaciones, realizamos este trabajo con el objetivo de estudiar la eficiencia de plata y oro soportados en zeolitas naturales y sintéticas como un sistema para evitar el desarrollo bacteriano de E. coli y S. typhi. 
Existen antecedentes del uso de zeolitas como soportes de materiales para la desinfección de los efluentes de procesos biológicos aerobios y anaerobios. Se aplican para evitar la propagación de ciertos organismos que producen patologías al hombre. Se han realizado numerosos estudios con zeolitas naturales, demostrándose sus efectos bactericidas sobre aquellos organismos presentes en las aguas residuales y en los efluentes de desechos sólidos. Los metales soportados en zeolitas naturales son elementos que, dependiendo de su naturaleza y su concentración en un medio determinado, pueden ejercer diferentes efectos sobre los microorganismos por ejemplo, en pequeñas cantidades son catalizadores del crecimiento microbiano pero a partir de determinadas concentraciones, son inhibidores microbianos.

\subsubsection{Los soportes tipo zeolita}

Las zeolitas y los materiales zeolíticos son sólidos cristalinos microporosos que contienen cavidades y canales de dimensiones moleculares (de 3 a $20 \AA$ ), que pueden acomodar moléculas en esos poros. Según la definición clásica, las zeolitas son aluminosilicatos cristalinos cuya celda unitaria tiene por fórmula general(Kesraoui-Ouki, 1994):

$$
\mathrm{Me}_{\mathrm{n}}\left[\left(\mathrm{AlO}_{2}\right)_{\times}\left(\mathrm{SiO}_{2}\right)_{\mathrm{y}}\left(\mathrm{H}_{2} \mathrm{O}\right)_{z}\right]
$$

siendo $\mathrm{n}, \mathrm{x}, \mathrm{y}, \mathrm{z}$ números enteros y Me un catión metálico. No obstante, en general, los materiales zeolíticos pueden contener además de Si y Al otros elementos como $\mathrm{V}, \mathrm{P}$ y Ti.

Las zeolitas se utilizan a nivel industrial en procesos de adsorción, de separación de gases, de catálisis e intercambio iónico(Bekkum H., 1991).La estructura de las zeolitas se basa en tetraedros covalentes $\mathrm{TO}_{4}$ en los que el átomo T suele ser $\mathrm{Si}$, Al o Ti. Lostetraedros se unen por los átomos de oxígeno formando una red tridimensional con canales y cavidades losuficientemente grandes como para albergar cationes y algunas moléculas pequeñas tales como agua o algunos hidrocarburos. La sustitución isomórfica de átomos desilicio por 
Capítulo 2

átomos de aluminio genera un exceso decarga negativa que se neutraliza por cationes. Estos cationes ocupan posiciones poco estables y esto le confiere a la zeolita su capacidad de intercambio catiónico. La regla deLöwenstein establece que en una estructura zeolíticano pueden haber uniones Al-O-Al, es decir dos tetraedros $\left[\mathrm{AlO}_{4}\right]$ vecinos. Por tanto, el valor mínimo de larelación Si/Al es 1. Una relación Si/Al baja implica un elevado número de cationes en los porosde la zeolita que originan fuertes campos electrostáticoslocales e interaccionan fuertemente con los adsorbatosmás polares. El intercambio iónico en las zeolitasdepende de la naturaleza del catión (tipo, tamaño ycarga), de la temperatura, de la concentración deespecies catiónicas en disolución, del tipo de anión asociado a la disolución catiónica, del disolvente y de lascaracterísticas estructurales de la zeolita.

\subsubsection{Aplicaciones de las zeolitas}

Las zeolitas han encontrado una gran variedad de aplicaciones, principalmente como adsorbentes, intercambiadores iónicos, catalizadores y soportes de catalizadores. El empleo de zeolitas como adsorbentes se debe a sus propiedades de tamiz molecular, gran volumen de huecos (en el caso de las zeolita A y $X$ puede llegar hasta un 50\%) y un carácter hidrofílico/hidrofóbico distintivo en función de su contenido de aluminio (Davis M., 1991). Se utilizan en procesos de purificación (Tabla 2.1) dada la selectividad de su superficie para adsorber moléculas polares o polarizables,recuperación de metales valiosos y en procesos de separación(Langella A., 2000; Tenorio J., 2001).

Tabla 2.1 Principales aplicaciones comerciales de las zeolitas como adsorbentes.

\begin{tabular}{|c|c|}
\hline SEPARACIONES & PURIFICACIONES \\
\hline $\begin{array}{l}\text { - } \text { n-Parafinas e isoparafinas. } \\
\text { - } \text { Xilenos. } \\
\text { - } \mathrm{O}_{2} \text { del aire. } \\
\text { - Criogénica de aire. } \\
\quad \text { Azúcares (fructosa en mezcla con } \\
\text { dextrosa). }\end{array}$ & $\begin{array}{l}\text { - Secado de gas natural, gas de craqueo, } \\
\text { refrigerantes. } \\
\text { - } \quad \begin{array}{l}\text { Anticontaminantes en la remoción de } \\
\mathrm{Hg}, \mathrm{NO}_{x}, \mathrm{SO}_{\mathrm{x}}\end{array} \\
\text { - Eliminación de } \mathrm{CO}_{2} \text { del gas natural. } \\
\text { - Extracción de compuestos sulfurados } \\
\text { del gas del petróleo. }\end{array}$ \\
\hline
\end{tabular}


Las zeolitas, por su capacidad de intercambiarcationes, particularmente de metales pesados, se emplean enel tratamiento de remoción de metales pesados de aguas residuales industriales y municipales y como intercambiadores iónicos en la remoción de iones amonio y recuperación de radioisótopos (Weber W., 2003; Kesraoui-Ouki S. et al., 1994; Leyva-Ramos R. et al., 2004). Las zeolitas se aplican en algunos procesos de intercambio iónico como aditivos para: extraer $\mathrm{Ca}^{2+}$ y $\mathrm{Mg}^{2+}$ (como aditivos de detergentes), extracción o recuperación de metales, remoción de radioisótopos $\left({ }^{239} \mathrm{Pu},{ }^{241} \mathrm{Pu},{ }^{134} \mathrm{Cs},{ }^{135} \mathrm{Cs},{ }^{137} \mathrm{Cs},{ }^{60} \mathrm{Co},{ }^{90} \mathrm{Sr}\right)$ en desechos nucleares, y remoción de $\mathrm{NH}_{4}{ }^{+}$en aguas residuales.

En los últimos 30 años se hasintetizado un gran número de zeolitas y su aplicación catalítica se ha expandido más allá de la industria de refinación del petróleo. Algunos ejemplos donde las zeolitas se aplican como catalizadores son:conversión de hidrocarburos (alquilación, craqueo, hidrocraqueo, isomerización), hidrodeshidrogenación, hidrodesalquilación, metanación, reformado selectivo, deshidratación, conversión de metanol en gasolina, catalizadores en reacciones como la oxidación de $\mathrm{H}_{2} \mathrm{~S}$, en la reducción de $\mathrm{NO}_{x}$ a $\mathrm{N}_{2}$, la oxidación de $\mathrm{CO}$, y catalizadores en reacciones de química fina.

La principal ventaja que presentan los tamices zeolíticos en catálisis es su sistema de poros bien definido, lo que permite llevar a cabo catálisis con selectividad de forma, evitando reacciones secundarias que conduce a la desactivación del catalizador. Entre los materiales zeolíticos más utilizados se encuentran las zeolitas ZSM-5, Beta, mordenita, faujasita X e Y. Otras ventajas que presentan los tamices zeolíticos son: superficies específicaselevadas, estabilidad térmicaelevada, capacidad para adsorber y concentrar hidrocarburos de cadenas largas, y acidez fácilmente controlable.

\subsubsection{Estructura de las zeolitas}

Estructuralmente, las zeolitas son caparazones de aluminosilicatos constituidos de una red tridimensional infinita de tetraedros de $\left(\mathrm{SiO}_{4}\right)^{4-}$ y $\left(\mathrm{AlO}_{4}\right)^{5-}$ unidos a través de los oxígenos y en los que la carga residual por la presencia de 
$\mathrm{Al}^{3+}$ en la red de silicio está neutralizada por cationes mono, di o trivalentes, orgánicos e inorgánicos.

Existen más de cien estructuraszeolíticas entre naturales y sintéticas. La combinación entre los tetraedros no es única; al contrario, existe una amplia gama de posibilidades para combinarse, lo que conduce a la existencia de numerosas estructuras zeolíticas, que se diferencian entre sí por el número y tipo de sistema de canales, la forma y tamaño de los poros y la existencia o no de cavidades.

La síntesis de nuevas zeolitas también incluye el estudio de la sustitución isomórfica total o parcial de átomos de $\mathrm{Al}^{3+} \mathrm{y} \mathrm{Si}^{4+}$, por otros cationes tales como $\mathrm{B}^{3+}$, $\mathrm{Ga}^{3+}, \mathrm{Cr}^{3+}, \mathrm{Fe}^{3+}, \mathrm{Ti}^{4+}, \mathrm{V}^{5+}$, etc., con el fin de ampliar las aplicaciones de estos materiales. En este sentido, existe el material denominado TS-1, que se caracteriza por la sustitución isomórfica de átomos de $\mathrm{Si}$ por átomos de $\mathrm{Ti}$ en posiciones tetraédricas de la estructura MFI. No presenta propiedades ácidas, ni capacidad de intercambio iónico, a diferencia de lo que sucede con las zeolitas que contienen aluminio, ya que los átomos de titanio presentan un estado de oxidación 4+, por lo que la red zeolítica es una estructura eléctricamente neutra. La presencia de átomos de titanio aislados y tetracoordinados dentro de la matriz zeolítica provoca que la zeolita TS-1 sea un catalizador altamente activo en reacciones de oxidación-reducción.

Las zeolitas que más se utilizana nivel industrial son las faujasitas (FAU), mordenitas (MOR), las silicalitas detipo MFI y la clinoptilolita (HEU). A continuación se mencionan algunas de sus característicasestructurales.

\subsection{Zeolita faujasita (FAU)}

Las zeolitas tipo FAU son de poro grande, contienen cavidades casi esféricas de unos $12 \AA$ de diámetro (figura 2.5a) interconectadas por ventanas de $7.4 \AA$ A(figura 2.5b). Las faujasitas pueden ser del tipo $\mathrm{X}$ o $\mathrm{Y}$ según el contenido de aluminio de lacelda unidad. Las faujasitas con densidad de aluminioentre 96 y 77 $\mathrm{Al} /$ celda unidad serán de tipo $\mathrm{X}$ y aquellascon densidades menores de $\mathrm{Al}$ son tipo Y. En consecuencia, el número decationes de intercambio es superior en las 
faujasitastipo X.La zeolita $Y$ es una zeolita sintética isomórfica con la faujasita existente en la naturaleza. La unidad estructural básica de la zeolita Y es la sodalita, la cual consiste en un octaedro truncado, constituido por veinticuatro tetraedros de silicio o aluminio dispuestos de modo que conducen a seis ventanas de cuatro miembros y a ocho de seis. La conexión entre las distintas unidades de sodalita se realiza por puentes de oxígeno a través de las caras con ventanas de seis miembros, resultando la estructura representada en la figura $2.5 \mathrm{a}$, característica de la zeolita Y. Presenta una cavidad central, "la gran cavidad", que se enlaza tridimensionalmente con las unidades siguientes a través de canales limitados por ventanas de doce átomos de oxígeno (Dwyer J., 1984).

(a)

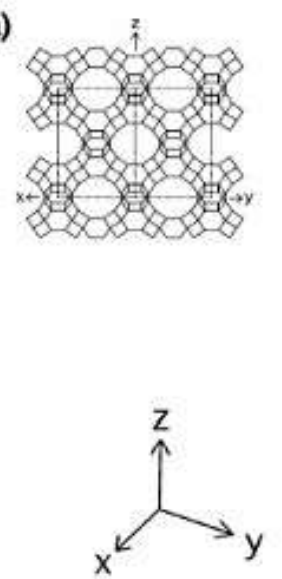

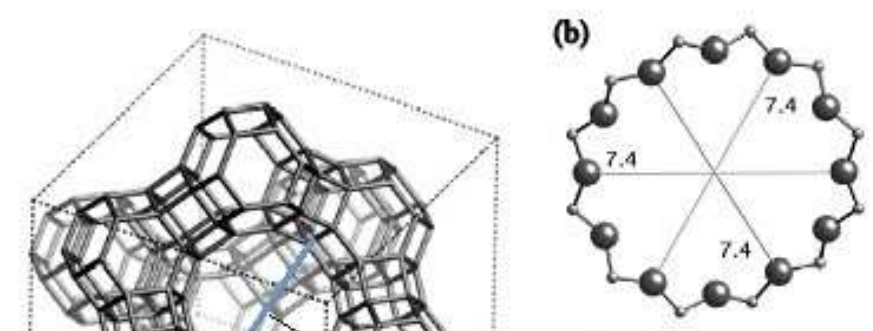

[111] $127,4 \times 7,4$

Figura 2.5. (a) Estructura de la zeolita faujasita (FAU), (b) anillos de 12 tetraedros que forman las ventanas de los canales.

\subsection{Zeolita mordenita (MOR)}

La mordenita es una zeolita presente en la naturaleza que posee un sistema de canales de 12 miembros de dimensiones 6.5 x $7.0 \AA$ (figura $2.6 a$ ) que se encuentran interconectados entre ellos por medio de otro sistema de canales de menor tamaño $(5.7 \times 2.6 \AA)$, figura $2.6 b$. 
(a)

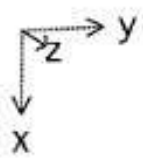

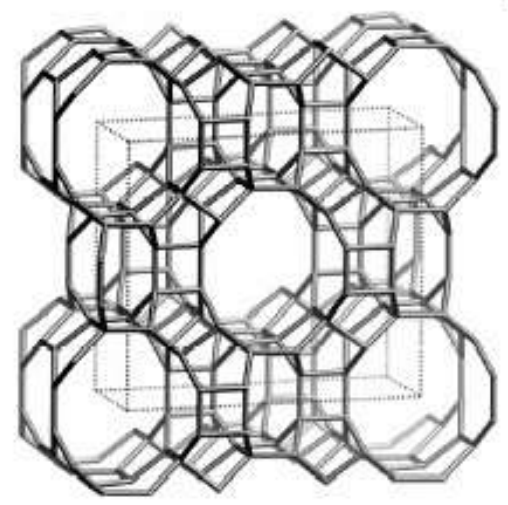

b)

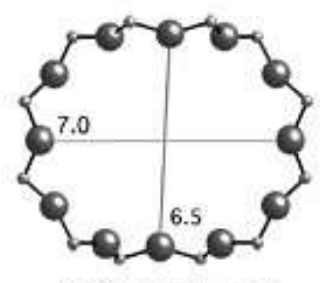

[001] $126,5 \times 7,0$

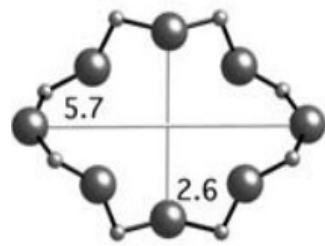

Figura 2.6. (a) Estructura de la zeolita mordenita (MOR), (b) anillos de 12 tetraedros que forman las ventanas de los canales.

\subsection{Zeolita silicalita TS-1 (MFI)}

El tamiz molecular TS-1 es una zeolita similar a la ZSM-5, que pertenece a la familia de las zeolitas con estructura MFI (figura 2.7a). La TS-1 se sintetizó por primera vez en 1983 (Taramasso M., 1983) y ha recibido gran atención debido a sus propiedades catalíticas. Los átomos de titanio localizados en la estructura de la zeolita funcionan como centros activos para reacciones de oxidación de varios compuestos orgánicos (fase líquida, peróxidos como agentes oxidantes y temperaturas bajas). Su estructura, sin grandes cavidades, posee una red tridimensional de canales con un tamaño de poro medio de $5.3 \times 5.5 \AA$, figura $2.7 \mathrm{~b}$. Estas características, en conjunto, le confieren una elevada selectividad de forma y una gran estabilidad térmica. Se ha determinado que el titanio se encuentra presente en la estructura como $\mathrm{Ti}^{4+}$, ocupando posiciones tetraédricas (Perego G. et al, 1986; Tuel A. et al, 1990; Geobaldo F. et al, 1992). El resultado es una estructura eléctricamente neutra, lo que conlleva a las siguientes consecuencias: la capacidad de intercambio iónico es prácticamente nula y no existen centros ácidos fuertes. Sin embargo, se ha observado que los centros de titanio son catalíticamente activos en un gran número de reacciones de oxidación parcial de compuestos orgánicos. 
Capítulo 2
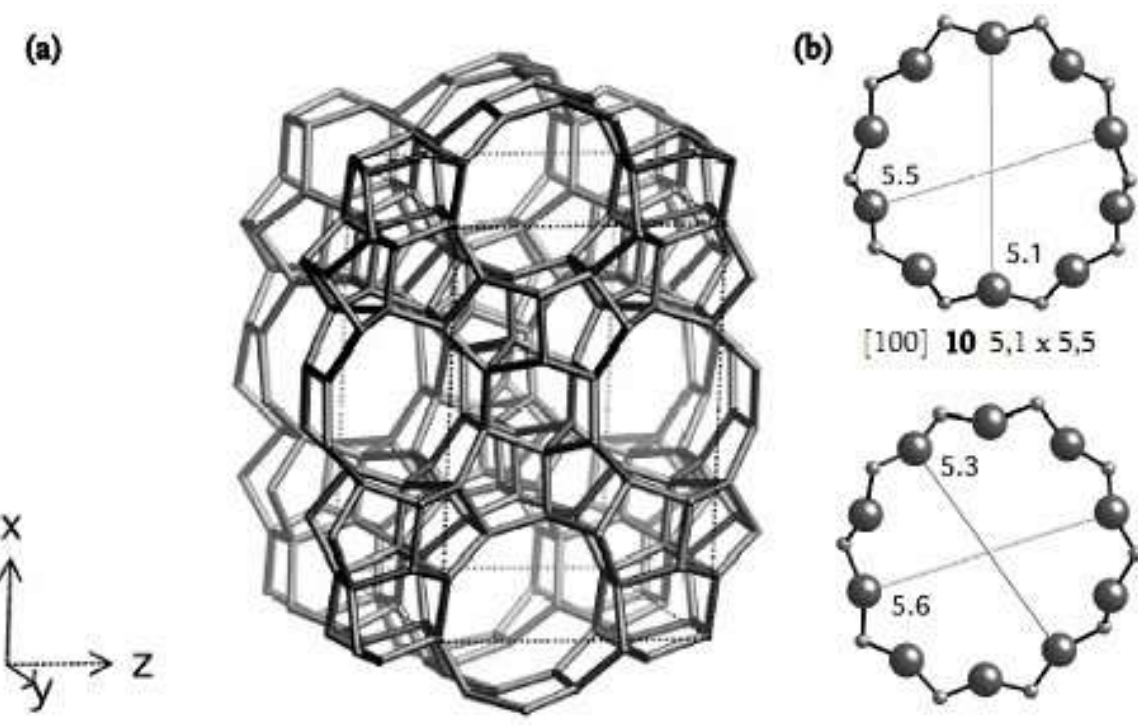

[100] $105,1 \times 5,5$

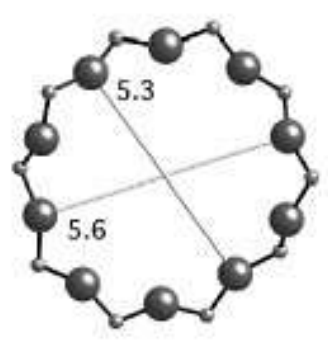

Figura 2.7. (a) Estructura de la zeolita silicalita (MFI), (b) anillos de 10 tetraedros que forman las ventanas de los canales.

\subsection{Zeolita clinoptilolita}

La clinoptilolita es una zeolita presente en la naturaleza que posee un sistema de canales de 8 a 10 miembros de dimensiones $7.5 \times 3.1 \AA$ (figura $2.8 a$ ) que se encuentran interconectados entre sí por medio de otro sistema de canales de menor tamaño (4.6 x $3.6 \AA$ ) figura $2.8 b$.

(a)

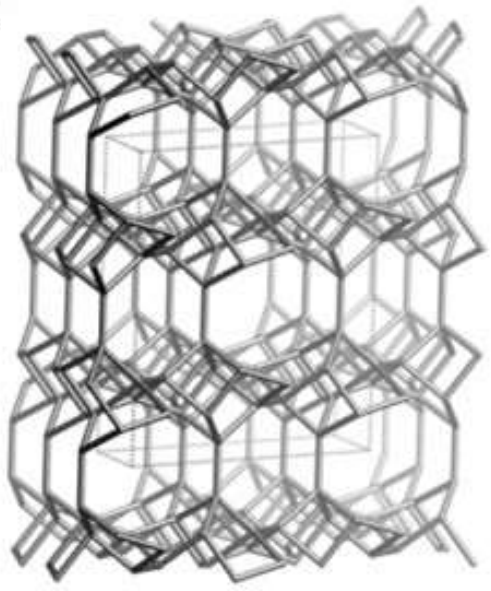

(b)
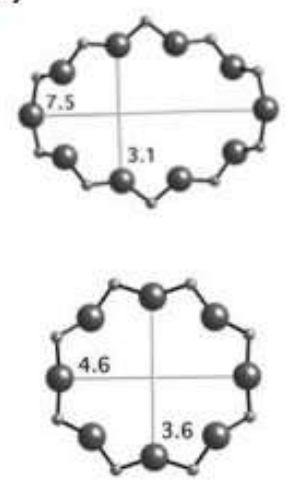

Figura 2.8. (a) Estructura de la zeolita clinoptilolita, (b) anillos de 8 y 10 tetraedros que forman las ventanas de los canales. 


\subsubsection{Clasificación de las Zeolitas}

Las zeolitas se clasifican de acuerdo al tamaño de poro y al número de átomos de oxígeno que forman los anillos por los cuales se penetra a los poros, Tabla 2.2 (Csicsery S., 1985; Derouane E., 1984). El tamaño de poro se determina, principalmente, por el número de unidades de tetraedros que conforman las dimensiones del poro y de la naturaleza de los cationes que se localizan en el poro.

Tabla 2.2. Clasificación de las zeolitas en función del tamaño de poros y número de átomos de oxígeno.

\begin{tabular}{|l|c|c|c|}
\hline \multicolumn{1}{|c|}{ Zeolita } & $\begin{array}{c}\text { Átomos de O en la } \\
\text { abertura }\end{array}$ & $\begin{array}{c}\text { Diámetro de poro } \\
\theta(\AA)\end{array}$ & Ejemplo \\
\hline Poro extragrande & 18 & $\theta>9$ & VPI-5 \\
\hline Poro grande & 12 & $6<\theta<9$ & $\begin{array}{c}\text { Y, } \beta, \Omega, \text { Mordenita, } \\
\text { Clinoptilolita, } \\
\text { Faujasita X,Y }\end{array}$ \\
\hline Poro medio & 10 & $5<\theta<6$ & ZSM-5, ZSM-11 \\
\hline Poro pequeño & 8 & $3<\theta<5$ & erionita, A, SAPO 4 \\
\hline
\end{tabular}

Otras características importantes a considerar en las zeolitas son (Meier W. et al., 1996):

- Densidad estructural (FD), definida como el número de átomos T por $1000 \AA$. La $F D$ está directamente relacionada con el volumen de los poros, pero no refleja la apertura o dimensión de los poros. El intervalo de valores de $F D$ para las zeolitas parte de 12.5, para estructuras totalmente cerradas, hasta valores alrededor de 20.5 para grandes volúmenes de poros.

- Lazos de configuración de átomos $T$, muestra el número de anillos de 3 o 4 miembros ligados a un átomo $\mathrm{T}$.

- Secuencia de coordinación (CS), lo primero permite obtener información de cómo los átomos $\mathrm{T}$ se conectan con los átomos $\mathrm{T}$ vecinos, y estos con los siguientes y así sucesivamente. CS es una función periódica.

La variación de relación de Si/Al conduce a las diferentes estructuras cristalinas de las zeolitas, producto de un orden-desorden estructural o del tipo de 
Capítulo 2

catión extraestructural. Las zeolitas se clasifican de acuerdo a su estructura cristalina, Tabla 2.3(Gottardi G., 1978).

Tabla 2.3. Clasificación estructural de las zeolitas.

\begin{tabular}{|c|c|c|}
\hline ZEOLITA & $\mathrm{TO}_{4}$ & Si/Al \\
\hline \multicolumn{3}{|c|}{ Grupo C4, Grupo de la Filipsita } \\
\hline Li-ABW & 8 & \multirow{9}{*}{$1^{-3}$} \\
\hline Filipsita & 16 & \\
\hline Harmotoma & 16 & \\
\hline Gismondita & 16 & \\
\hline $\mathrm{Na}-\mathrm{P}$ & 16 & \\
\hline Amicita & 16 & \\
\hline Garronita & 16 & \\
\hline Yugawaralita & 16 & \\
\hline Merlinoita & 32 & \\
\hline \multicolumn{3}{|c|}{ Grupo C4-C4, Grupo de la Analista } \\
\hline Anacita & 48 & \multirow{5}{*}{$1^{-3}$} \\
\hline Leucita & 48 & \\
\hline Waieakita & 48 & \\
\hline Pollucita & 48 & \\
\hline A & 192 & \\
\hline \multicolumn{3}{|c|}{ Grupo C4=T1, Grupo de la Natrolita } \\
\hline Edingtonita & 10 & \multirow{6}{*}{$1^{-3}$} \\
\hline Gonnardita & 20 & \\
\hline Thomsonita & 40 & \\
\hline Natrolita & 40 & \\
\hline Scolecita & 40 & \\
\hline Mesolita & 120 & \\
\hline \multicolumn{3}{|c|}{ Grupo C5-T1, Grupo de la Mordenita } \\
\hline Bikitaita & 9 & \multirow{8}{*}{$4-7$} \\
\hline Deschiardita & 24 & \\
\hline Epistibita & 24 & \\
\hline Ferrierita & 36 & \\
\hline Mordenita & 48 & \\
\hline Clinoptilolita & 48 & \\
\hline ZSM-5 & 96 & \\
\hline ZSM-11 & 96 & \\
\hline
\end{tabular}

\begin{tabular}{|c|c|c|}
\hline ZEOLITA & $\mathrm{TO}_{4}$ & $\overline{\mathrm{Si} / \mathrm{Al}}$ \\
\hline \multicolumn{3}{|c|}{ Grupo C6, Grupo de la Chabazita } \\
\hline Sodalita & 12 & \multirow{11}{*}{$\begin{array}{l}2.5- \\
4.0\end{array}$} \\
\hline Cancrinita & 12 & \\
\hline Ofertita & 18 & \\
\hline Losod & 24 & \\
\hline Gmelinita & 36 & \\
\hline Liotita & 36 & \\
\hline Chabazita & 36 & \\
\hline Mazzita & 36 & \\
\hline Erionita & 36 & \\
\hline Aghanita & 48 & \\
\hline Levynita & 54 & \\
\hline \multicolumn{3}{|c|}{ Grupo de C6-C6, Grupo de la Faujasita } \\
\hline Linde & 24 & \multirow{6}{*}{$1^{-3}$} \\
\hline Rho & 46 & \\
\hline ZK-5 & 96 & \\
\hline Faujasita & 192 & \\
\hline Paulingita & 672 & \\
\hline Linde $\mathrm{N}$ & 768 & \\
\hline \multicolumn{3}{|c|}{$\begin{array}{l}\text { Grupo C4-C4=T1, Grupo de } \\
\text { la Heulandita }\end{array}$} \\
\hline Brewsterita & 16 & \multirow{5}{*}{$\begin{array}{l}2.5- \\
5.0\end{array}$} \\
\hline Heulandita & 36 & \\
\hline Stilbita & 72 & \\
\hline Stellerita & 72 & \\
\hline Barretita & 72 & \\
\hline \multicolumn{3}{|l|}{$\begin{array}{l}\text { Grupo C8, Grupo de la } \\
\text { Laumontita }\end{array}$} \\
\hline Laumontita & 24 & $1-2$ \\
\hline
\end{tabular}




\subsubsection{Plata y oro soportados en zeolitas}

Las zeolitas son excelentes candidatas como soportes de Ag y Au porque además de su alta área superficial son versátiles en cuanto a la forma de poros.

La plata y el oro pueden incorporarse a los soportes, ya sea como complejos orgánicos, partículas metálicas o bien como cationes $\mathrm{Ag}^{+} \mathrm{yAu}^{\mathrm{n}+}$. Esta última forma es la que más se ha estudiado debido a la facilidad de incorporar los cationes de $\mathrm{Ag}^{+}$a la zeolita por intercambio iónico (Im K., 1996). La actividad antimicrobiana de la zeolita modificada con plata debería en principio depender de la interacción del metal con el soporte, que a su vez la determina el tipo de zeolita, la concentración de plata, etc. (Rosabal B. et al, 2005).

Orha C. et al, (Orha C.et al, 2008)reportaron uno de los pocos trabajos en donde se evaluaron las propiedades antibacteriales de una zeolita natural con plata. Al poner los microorganismos en contacto con la zeolita con plata seelimina el $100 \%$ de coliformes a altas temperaturas después de 31 días, $100 \%$ de bacteriascoliformes después de 45 días y $100 \%$ de enterococos después de 7 días de contacto.

El trabajo de Orha muestra la viabilidad del uso de zeolitas como soportes de plata antibacterial. 


\section{Capítulo 3. Objetivos e hipótesis}

3.1 Objetivo general

- Evaluar las propiedades bactericidas de partículas de plata y oro soportadas en materiales porosos zeoliticos, frente a las bacterias E. coli y

S. typhi.

\subsubsection{Objetivos específicos}

- Evaluar el efecto que tiene el soporte (zeolita) en las propiedades bactericidasde las partículas metálicas ( $\mathrm{Au}$ y $\mathrm{Ag}$ ).

- Determinar las concentraciones mínimas inhibitorias (CMI) y concentraciones mínimas de bactericida ( $\mathrm{CMB}$ ) de los materiales biocidas en estudio para inhibir la E. coli y S. typhi.

\subsection{Hipótesis}

La plata y el oro,por su afinidad a reaccionar con el azufre, pueden interactuar con los grupos sulfihidrilos $(-\mathrm{SH})$ de las enzimas, inhibiendo la actividad enzimática de los liposomas. Un mayor efecto bactericida de la plata y el oro se consigue al incorporarlos en zeolitas para tener una mayor área activa. 


\section{Capítulo 4. Parte experimental}

\subsection{Materiales}

Se prepararon una serie de materiales de Clinoptilolita con 2.1 y $4.0 \%$ en peso de plata, utilizando $\mathrm{AgNO}_{3}$. Para favorecer la reducción de la plata y la incorporación del metal, los materiales se sometieron a tratamientos térmicos en flujo de $\mathrm{H}_{2}$ a 500 o $700{ }^{\circ} \mathrm{C}$. Los materiales soporte-Ag preparados se pusieron en contacto con las bacterias para explorar el efecto de la concentración del metal, la temperatura de reducción y el tiempo de contacto en las propiedades biocidas del material. Así se definieron los parámetros de \% de metal y de temperatura de reducción para utilizarlos en los otros soportes.

Además de la clinoptilolita, se usó como soporte a la zeolita faujasita $Y$, que es una zeolita sintética con relación Si/Al similar a la clinoptilolita pero son muy diferentes en densidad. También se utilizó como soporte a la mordenita que es una zeolita con canales diferentes a los de la clinoptilolita y faujasita. Además, se sintetizóla silicalita, que es un soporte que no contiene aluminio, contiene silicio y pequeñas cantidades de titanio, al cual se le puede cargar con una menor cantidad de plata o de oro ya que no que no los incorporará a sus canales por intercambio iónico.

Los reactivos utilizados para la impregnación o síntesis fueron grado reactivo Sigma Aldrich. 


\subsubsection{Soportes}

\subsubsection{Clinoptilolita}

Se molió y tamizó $(0.15 \mathrm{~mm})$ una toba rica en clinoptilolita, procedente de Etla, Oaxaca, en el sureste de México. Con el fin de homogeneizar su capacidad de intercambio catiónico, la zeolita se convirtió a la forma homoionica de sodio: el material de zeolita se trató con una solución $5 \mathrm{M}$ de $\mathrm{NaCl}$ por 8 días, se lavó con agua desionizada hasta que no hubo presencia de iones cloruro. La clinoptilolita tratada con $\mathrm{Na}^{+}$se secó a $80^{\circ} \mathrm{C}$ por $12 \mathrm{~h}$.

\subsubsection{Faujasita $Y$}

La zeolita de tipo faujasita con una relación molar de Si/Al de 5.1 y un área específica de $925 \mathrm{~m}^{2} / \mathrm{g}$, se adquirió en zeolyst International (USA). La zeolita en su forma amoniacal $\mathrm{NH}_{4}{ }^{+}-\mathrm{Y}$ se calentó a $400^{\circ} \mathrm{C}$ por $6 \mathrm{~h}$ para obtener la forma protonada, HY.

\subsubsection{Mordenita}

Lazeolita $\mathrm{NH}_{4}{ }^{+}$-mordenitacon una relaciónmolarSi/Al de20se adquirió enZeolystInternacional(USA). La $\mathrm{H}^{+}$-mordenita(HM) se preparó por calentamiento deNH${ }_{4}{ }^{+}$-mordenitaa $400{ }^{\circ} \mathrm{C}$ por $6 \mathrm{~h}$.

\subsubsection{Silicalita}

Se disolvieron $25.2 \mathrm{~g}$ de hidróxido de tetrapropilamonio (TPAOH 25\% en peso) en $48.0 \mathrm{~mL}$ de $\mathrm{H}_{2} \mathrm{O}$. Esta solución se mezcló con $21.0 \mathrm{~g}$ de tetraetilo de ortosilicato y se agitó por $30 \mathrm{~min}$, se agregó gota a gota ortotitanato tetrabutil a temperatura ambiente. Después de agitar por $12 \mathrm{~h}$ a temperatura ambiente, se añadieron $12.0 \mathrm{~g}$ de policloruro de acrilamida-co-dialildimetilamonio (10\% en peso en agua). La mezcla resultante se agitó por $24 \mathrm{~h}$ a temperatura ambiente. Después se secoen una autoclave de acero inoxidable a $80{ }^{\circ} \mathrm{C}$ por $120 \mathrm{~min}$. El producto se secó a $100{ }^{\circ} \mathrm{C}$ por $24 \mathrm{~h}$, y se calcinó en aire a $500{ }^{\circ} \mathrm{C}$ por $5 \mathrm{~h}$. Se 
Capítulo 4

suspendió $1.0 \mathrm{~g}$ de este sólido calcinado en $100 \mathrm{~mL}$ de agua, se añadió una solución acuosa $1.0 \mathrm{M}$ de $\mathrm{NaOH}$ gota a gota con agitación vigorosa a temperatura ambiente hasta que el pH alcanzó un valor de 12 y se mantuvo en agitación por 2

h. El sólidose separó porfiltración, se lavó 5vecescon2L(total) deaguapara eliminarel $\mathrm{NaOH}$ residual y luego se secó a $100^{\circ} \mathrm{C}$ por una noche. La silicalita así obtenida se nombró como Silic.

\subsubsection{Soportes- $A g$}

\subsubsection{Clinoptilolita-Ag}

$5 \mathrm{~g}$ de zeolita clinoptilolita sódica se agitaron por $3 \mathrm{~h}$ en $100 \mathrm{~mL}$ de solución $0.1 \mathrm{M} \circ 0.05 \mathrm{M}$ de $\mathrm{AgNO}_{3}$. Las muestras se separaron por centrifugación y se secaron a $80{ }^{\circ} \mathrm{C}$. Posteriormente, las muestras se redujeron a 500 (o 700) ${ }^{\circ} \mathrm{C}$ en $\mathrm{H}_{2}$ (5 $\mathrm{mL} / \mathrm{min}$ ) por $4 \mathrm{~h}$. La tabla 4.1 resume las muestras en estudio, la nomenclatura adoptada es ClinoAg- $\mathrm{X}-\mathrm{Y}$, donde $\mathrm{X}$ es la temperatura de reducción y Y es la cantidad de plata (\% en peso), según se determinó por espectroscopia de absorción atómica.

\subsubsection{Faujasita Y-Ag}

La zeolita HY $(2.5 \mathrm{~g})$ se suspendió en $50 \mathrm{~mL}$ de solución $0.05 \mathrm{M}$ de $\mathrm{AgNO}_{3}$. Después de $3 \mathrm{~h}$ el sólido se separó por centrifugación, se lavó tres veces con agua destilada, se secó a $80{ }^{\circ} \mathrm{C}$ y se redujo a $500{ }^{\circ} \mathrm{C}$ en un flujo de $\mathrm{H}_{2}(10 \mathrm{~mL} / \mathrm{min})$ por 4 h. La cantidad de plata en el sólido fue de $2.1 \%$ en peso. La muestra de $\mathrm{Ag}$ preparada se nombró como FaujaAg-500-2.1 (Tabla 4.1).

\subsubsection{Silicalita-Ag}

Un gramo de Silic se suspendió en $50 \mathrm{~mL}$ de una solución $0.03 \mathrm{M}$ de $\mathrm{AgNO}_{3}$. Después de $48 \mathrm{~h}$, el sólido se separó por centrifugación, se lavó tres veces con agua destilada, se secó a $80{ }^{\circ} \mathrm{C}$ y se redujo a $500{ }^{\circ} \mathrm{C}$ en un flujo de $\mathrm{H}_{2}(10 \mathrm{~mL} / \mathrm{min})$ por 4 h. La muestraasípreparada senombró como SilicAg-500-0.11 (Tabla 4.1). 
Tabla 4.1.Contenido de Ag en los materiales soporte-Ag.

\begin{tabular}{|c|c|c|}
\hline Muestra & $\begin{array}{l}\text { Temperatura de } \\
\text { reducción }\left({ }^{\circ} \mathrm{C}\right)\end{array}$ & $\begin{array}{c}\text { Contenido } \mathrm{Ag}^{*} \\
(\% \text { peso })\end{array}$ \\
\hline ClinoAg-500-2.1 & 500 & 2.1 \\
\hline ClinoAg-700-2.1 & 700 & 2.1 \\
\hline ClinoAg-500-4.0 & 500 & 4.0 \\
\hline ClinoAg-700-4.0 & 700 & 4.0 \\
\hline FaujaAg-500-2.1 & 500 & 2.1 \\
\hline SilicAg-500-0.11 & 500 & 0.11 \\
\hline
\end{tabular}

\subsubsection{Soportes-Au}

\subsubsection{Clinoptilolita-Au}

$2 \mathrm{~g}$ de zeolita clinoptilolita en su forma sódica se agregó a $25 \mathrm{~mL}$ de una solución coloidal de oro $\left(0.01 \% \mathrm{HAuCl}_{4}\right)$. La suspension se agitó a temperatura ambiente por 3h. La muestra se separó por centrifugación y se secó a $80^{\circ} \mathrm{C}$. Posteriormente, la muestra se redujo a $500^{\circ} \mathrm{C}$ en flujo de $\mathrm{H}_{2}(5 \mathrm{~mL} / \mathrm{min})$ por $4 \mathrm{~h}$. La muestra así preparada se llamó ClinoAu-500-2.5 (Tabla 4.2).

\subsubsection{Mordenita-Au}

Lazeolita HM semezclócon una soluciónacuosa conteniendo $\mathrm{Au}\left(\mathrm{NH}_{3}\right)_{4}\left(\mathrm{NO}_{3}\right)_{3}$. El $\mathrm{Au}\left(\mathrm{NH}_{3}\right)_{4}\left(\mathrm{NO}_{3}\right)_{3}$ sedisolvió enuna soluciónacuosa sobresaturada de $\mathrm{NH}_{4} \mathrm{NO}_{3}$, a esta solución se añadió gota a gota una soluciónde $\mathrm{NH}_{4} \mathrm{OH}$ hasta alcanzar un $\mathrm{pH}$ de 7 , seguido de una agitación por $24 \mathrm{~h}$. Las muestras se filtraron y se lavaron con agua desionizada, enseguida se redujeron a $500{ }^{\circ} \mathrm{C}$ en flujo de $\mathrm{H}_{2}$ (20 $\mathrm{mL} / \mathrm{min})$ por $2.5 \mathrm{~h}$. Las muestras preparadas a diferentes concentraciones de $\mathrm{Au}$ se llamaron MordeAu-500-1.7 y MordeAu-500-2.9. La tabla 4.2 resume las muestras soporte-Au en estudio.

\subsubsection{Faujasita Y-Au}

La zeolita HY se suspendió en una solución coloidal de oro $(5 \mathrm{~nm})$. Después de 30 min, el sólido se separó por centrifugación, se lavó tres veces con agua 
destilada, se secó a $80^{\circ} \mathrm{Cy}$ se redujo a $500^{\circ} \mathrm{Cen}$ un flujo de $\mathrm{H}_{2}(10 \mathrm{~mL} / \mathrm{min})$ por $4 \mathrm{~h}$. La cantidad de oro en el catalizador fue de $2.6 \%$ en peso.La muestra de Aupreparada senombró como FaujaAu-500-2.6 (tabla 4.2).

\subsubsection{Silicalita-Au}

Laincorporación deAuenSilicfue vía deposición-precipitación (DP): $1.0 \mathrm{~g}$ de

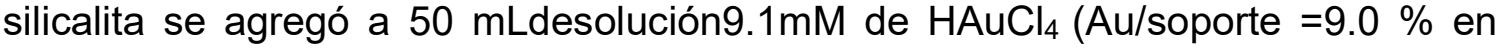
peso), y luego se agregó gota a gotauna solución acuosa de $\mathrm{NaOH}$ hasta alcanzar un $\mathrm{pH}$ de 9. La suspension se agitó a temperature ambiente por $3 \mathrm{~h}$, manteniendo el $\mathrm{pH}$ constante a 9, mediante la adición desolución acuosa de $\mathrm{NaOH}$. El sólido se separó por centrifugación, se lavó con $50 \mathrm{~mL}$ de agua, se centrifugó nuevamente y se secó a temperature ambiente por una noche. Las muestras de Au preparada se redujo a $500{ }^{\circ} \mathrm{C}$ en un flujo de $\mathrm{H}_{2}(10 \mathrm{~mL} / \mathrm{min})$ por $4 \mathrm{~h}$. La muestra de Au preparada según este método senombró como SilicAu-500-0.11 (Tabla 4.2).

Tabla 4.2.Contenido de Au en los materiales soporte-Au.
\begin{tabular}{|c|c|c|}
\hline Muestra & $\begin{array}{c}\text { Temperatura de } \\
\text { reducción }\left({ }^{\circ} \mathrm{C}\right)\end{array}$ & $\begin{array}{c}\text { Contenido Au } \\
(\% \text { peso })\end{array}$ \\
\hline ClinoAu-500-2.5 & 500 & 2.5 \\
\hline FaujaAu-500-2.5 & 500 & 2.5 \\
\hline SilicAu-500-0.11 & 500 & 0.11 \\
\hline MordeAu-500-1.7 & 500 & 1.7 \\
\hline MordeAu-500-2.9 & 500 & 2.9 \\
\hline
\end{tabular}

\subsubsection{Materiales biológicos}

\subsubsection{Preparación de caldos nutritivos}

El caldo soya tripticaseína se preparó según las indicaciones del fabricante. Después de esterilizarse en autoclave, se dejó enfriar a temperatura ambiente (en forma estéril bajo campana de flujo laminar). Se agregaron $18 \mathrm{~mL}$ de caldo en tubos de ensaye con tapa rosca, en condiciones asépticas.

El caldo de Müeller-Hintonse preparó siguiendo las instrucciones del fabricante y suplementado con $\mathrm{Ca}^{2+} \mathrm{y} \mathrm{Mg}^{2+}$, ajustando a una concentración final de $25 \mathrm{mg}$ de $\mathrm{Ca}^{2+} / \mathrm{L}$ y $12.5 \mathrm{mg}$ de $\mathrm{Mg}^{2+} / \mathrm{L}$ de caldo. 


\subsubsection{Preparación de placas de agar}

Los agares soya tripticaseína, Müller-Hinton, MacConkey y verde brillante, se prepararon según las indicaciones del fabricante. Después de esterilizarse se introdujeron en autoclave, se dejaron enfriar en un baño de agua a $45-50{ }^{\circ} \mathrm{C}$ (en forma estéril bajo campana de flujo laminar). Se vertieron $30 \mathrm{~mL}$ de los preparados en cajas Petri de $100 \mathrm{~mm}$ de diámetro, para dar un espesor uniforme de aproximadamente $5 \mathrm{~mm}$. Las placas se dejaron solidificar a temperatura ambiente, evitando la acumulación de gotas de condensación en la tapa. Las placas preparadas se envolvieron en plástico, para minimizar el secado de los agares, y se almacenaron en refrigerador a $4{ }^{\circ} \mathrm{C}$.

\subsubsection{Cepas bacterianas}

Se utilizaron cepas de E. coli y S. typhi, obtenidas de la Escuela Nacional de Ciencias Biológicas del Instituto Politécnico Nacional (ENCB-IPN), las cuales se hicieron crecer en cuñas de agar soya tripticaseína a $35.5^{\circ} \mathrm{C}$ por $48 \mathrm{~h}$.

\subsubsection{Preparación de los inóculos}

Para la preparación de los inóculos se tomaron 3 colonias aisladas del mismo tipo de morfología de las cepas mantenidas en cuñas de agar soya tripticaseína, y se hicieron crecer en tubos con $10 \mathrm{~mL}$ de caldo de soya tripticaseína a las condiciones óptimas de temperatura para los microorganismos $\left(35.5^{\circ} \mathrm{C}\right)$. Los inóculos se resembraron cada 24 h por 3 días para mantener la fase exponencial de crecimiento.

\subsection{Caracterización de los materiales}

\subsubsection{Difracción de rayos- $X$}

Los patrones de difracción de rayos $X$ (por sus siglas en ingles $X R D$ ) de las muestras se obtuvieron en un difractómetro Siemens D500 que usa un tubo de 
Capítulo 4

cobre de rayos-X. La radiación Ka (longitud de onda de $0.70930 \AA$ ) se seleccionó con un monocromador de haz difractado.

\subsubsection{Dispersión de rayos $X$ a bajos ángulos}

Las curvas de dispersión de rayos X (SAXS) a ángulos pequeños se adquirieron en una cámara Kratky, acoplada a un tubo de ánodo de cobre. Los datos de SAXS se procesaron con el programa ITP (Glatter O.,1984), donde el parámetro angular $(h)$ se define como $h=4 \pi \sin \theta / \lambda$, siendo $\theta$ y $\lambda$ el ángulo de dispersión de rayos $\mathrm{X}$ y la longitud de onda, respectivamente.

\subsubsection{Resonancia magnética nuclear}

Los experimentos de resonancia magnética nuclear (RMN), de ${ }^{27} \mathrm{Al} \mathrm{y}^{29} \mathrm{Si}$ en estado sólido se realizaron en un espectrómetro Bruker Avance 400 a frecuencias de 104.2 y $79.4 \mathrm{MHz}$, respectivamente. Los espectros de RMN de ${ }^{29} \mathrm{Si}$ se adquirieron mediante el uso de las técnicas combinadas de giro en el ángulo mágico (MAS) y desacoplamiento dipolar del protón (HPDEC). Se emplearon pulsos sencillos de excitación (3 $\mu \mathrm{s})$ con un tiempo de repetición entre pulsos de $40 \mathrm{~s}$. Las muestras sólidas se empacaron en rotores de zirconio. Los rotores se giraron a una frecuencia de $5 \mathrm{kHz}$. Los desplazamientos químicos se expresan como ppm, con referencia al tetrametilsilano (TMS). Los espectros de RMN MAS de ${ }^{27} \mathrm{Al}$ se adquirieron con pulsos cortos ( $\left.\pi / 12\right)$ y tiempos de repetición de $0.5 \mathrm{~s}$. Las muestras se giraron a $10 \mathrm{kHz}$, y los desplazamientos químicos se referenciaron a una solución acuosa $1 \mathrm{M} \mathrm{AlCl}_{3}$.

\subsubsection{Microscopia electrónica de transmisión}

Los materiales se observaron en un microscopio electrónico de transmisión JEOLJEM-3000F equipado conun procesador de imagines (STEM). El voltaje de operación fue de $300 \mathrm{kV}$, y laresolución fuede $0.20 \mathrm{~nm}$. Se midieron al 
Capítulo 4

menos 200 partículas para determinar el diámetro medio mediante el uso de un analizador de imágenes computarizado (Nippon Aviónica C. Ltd., EXCEL).

\subsection{Evaluación de los materiales como bactericidas}

\subsubsection{Bactericida en medio líquido}

Para valorar la capacidad bactericida de los materiales se empleó la técnica de ensayo de dilución en caldo Müller-Hinton, la cual proporcionó información preliminar acerca de la actividad antimicrobiana. En los ensayos de dilución en caldo, en 6 tubos de ensaye con la misma cantidad de caldo soya tripticaseína (18 $\mathrm{mL}$ ), se agregó una cantidad de material bactericida, para obtener diluciones dobles y progresivas de agente microbiano. Los tubos fueron inoculados con una cantidad calibrada de los microorganismos de prueba (para garantizar una misma cantidad de bacterias en cada tubo), e incubados por $24 \mathrm{~h}$ a una temperatura de $35.5^{\circ} \mathrm{C}$. Uno de los tubos no contenía agente bactericida y se tomó como testigo o control. En aquellos tubos donde la bacteria se desarrolló, se observó una turbidez. Cuando el material biocida inhibió el crecimiento el medio de cultivo no presentó turbidez, determinando la concentración mínima inhibitoria (CMI), que es un punto de ruptura en el desarrollo bacteriano. Después de la incubación, los tubos en donde no hubo crecimiento fueron sembrados en agar Müller-Hinton, para determinar la concentración mínima de bactericida (CMB).

Las pruebas de turbidez se realizaron en un espectrofotómetro UV-Vis Varian Cary 4000. Se midió la absorbancia a $590 \mathrm{~nm}$, manteniendo los cultivos a $35.5^{\circ} \mathrm{C}$, para determinar el crecimiento o inhibición de los microorganismos. Esta medición se realizó diariamente por 3 días.

Una vez que no se observó turbidezen las muestras, se sembraron en cajas Petri con agar nutritivo para observar si el efecto de los materiales era bactericida o bacteriostático. 


\subsubsection{Bactericida en medio sólido}

La CMB de los materiales se determinó a través de la técnica de difusión en agar (método de Kirby-Bauer). Para ello, se inoculó una cantidad estandarizada de bacterias de S. typhi o E. coli sobre la superficie de una placa de agar Müller- Hinton. Se pusieron en contacto con discos de papel filtro impregnados con diferentes cantidades conocidas del material bactericida a evaluar.

Las bacterias fueron sembradas mediante la técnica de inoculación con el uso del replicador de Steer, el cual permite sembrar varias cepas en forma rápida y simultánea en el agar.

El replicador se calibró para depositar alícuotas de 1-2 $\mu \mathrm{L}$ de cada inóculo sobre la superficie del agar.

En cada ensayo se inoculó, como control, una placa sin material bactericida, al comienzo y al final, para determinar viabilidad (pureza) y detectar posibles contaminaciones durante el procedimiento. Las placas se mantuvieron a temperatura ambiente hasta secar el inóculo. Luego se incubaron invertidas a 35.5 ${ }^{\circ} \mathrm{C}$ por 24 h en atmósfera aeróbica. Se midieron los halos de inhibición de desarrollo, interpretándose los resultados como crecimiento (+) o ausencia de crecimiento (-).

\subsubsection{Crecimiento bacteriano en presencia de los materiales biocidas}

Se determinó el crecimiento de S. typhi y E. coli en presencia de los materiales biocidas. Para ello, se valoró la capacidad bactericida de los materiales en relación con el tiempo y con distintas concentraciones fijas de antimicrobiano.Se enfrentó un inóculo normalizado a concentraciones fijas de antimicrobiano en un caldo. Las concentraciones fueron la CMI de cada material biocida. Se inoculó $1 \mathrm{~mL}$ de muestra de los sistemas líquidos con bacterias (S. typhi o E. coli), en $18 \mathrm{~mL}$ de caldo de soya tripticaseína contenido en tubos de ensaye con tapa rosca. Se agregó una cantidad de material biocida (cantidad determinada como $\mathrm{CMI}$ ) a cada tubo incubándose a $35.5^{\circ} \mathrm{C}$ con agitación a $30 \mathrm{rpm}$. Se tomaron muestras a diferentes tiempos (0, 5, 30, 60, 90 y $120 \mathrm{~min})$. La 
Capítulo 4

muestra tomada se sembró en cajas Petri con $30 \mathrm{~mL}$ de agar selectivo (MacConkey para E. coli y verde brillante para S. typhi) por la técnica de estriado en placa. Como control, una placa se inoculó con cultivo sin material bactericida, al comienzo y al final. Las placas se incubaron invertidas a $35.5^{\circ} \mathrm{C}$ por $48 \mathrm{~h}$ en atmósfera aeróbica y se realizó el conteo de colonias. 


\section{Capítulo 5. Resultados y discusión}

\subsection{Materiales}

\subsubsection{Propiedades estructurales}

\subsubsection{Soportes-Ag}

\subsection{ClinoAg-X-Y}

La figura 5.1 muestra los patrones de difracción de rayos $X(D R X)$ de cuatro muestras ClinoAg-X-Y. Todos los difractogramas exhiben los picos asociados a la zeolita clinoptilolita. Los picos etiquetados como Pt corresponden a los planos característicos del platino, debido al portamuestras. Las muestras con plata presentan picos estrechos bien definidos, atribuibles a plata metálica, etiquetados con Ag. Entre mayor fue la cantidad de plata, más intenso fue el pico DRX de Ag. No se observaron diferencias significativas, dentro de los límites de la técnica de DRX, entre las muestras con el mismo contenido de plata reducida a una temperatura diferente. Estos resultados indican claramente que la estructura de la zeolita se conservó después de la deposición de plata. A bajas concentraciones, la plata metálica estuvo bien dispersada en la zeolita. Con el aumento de la cantidad de plata, las partículas pequeñas se aglomeran para formar otras más grandes, que se localizan principalmente en la superficie externa de la zeolita.

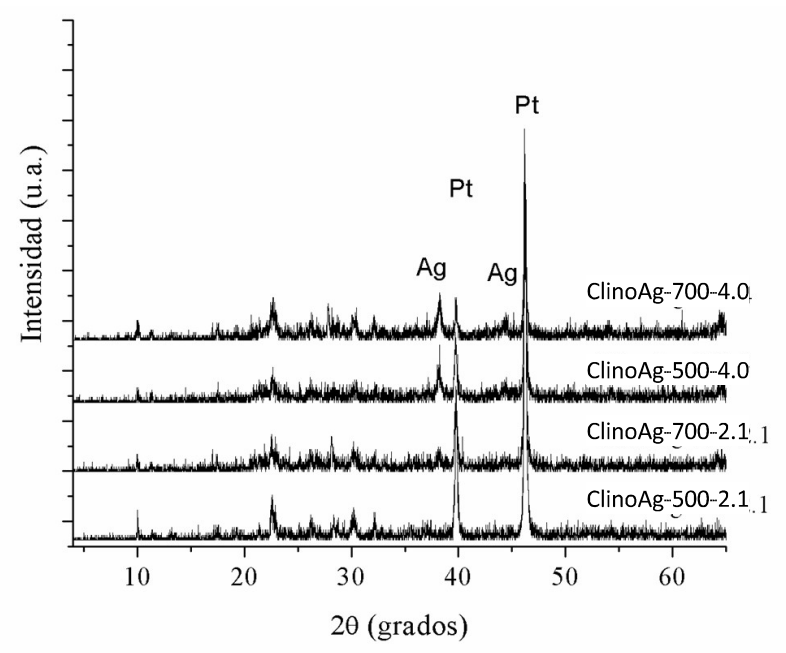

Figura 5.1. Patrones de difracción de rayos $X$ de las muestras ClinoAg-X-Y. 
Los espectros de ${ }^{29}$ Si RMN MASde las muestras ClinoAg-X-Yse presentan en la figura 5.2. En los espectros pueden observarse traslapes de las líneas de resonancia. Esto se debe a la baja simetría de la clinoptilolita y a la existencia de cinco sitios T diferentes (Alberti A., 1978), lo cual conduce a diferentes distancias T$\mathrm{T}$ y diferentes ángulos T-O-T. Se identificaron cuatro picos de resonancia, con desplazamientos químicos de $-95,-101,-108$ y -113 ppm, después de deconvolución. Estas señales de resonancia corresponden a las configuraciones $\mathrm{Si}$ (3Al), Si (2Al), Si (1Al) y Si (OAl), respectivamente (Fyfe C. et al, 1991). Las 4 muestras presentan espectros similares, apoyando la idea de que la estructura silícea no se modifica ni por la incorporación de la plata nipor el tratamiento térmico. La muestra sin plata presenta un pico $\mathrm{Si}(2 \mathrm{Al})$ ligeramente más intenso que las otras muestras, lo que sugiere que la incorporación de la plata se acompaña por una redistribución de aluminios, lo que es muy común y seguramente ocurre por el tratamiento térmico.

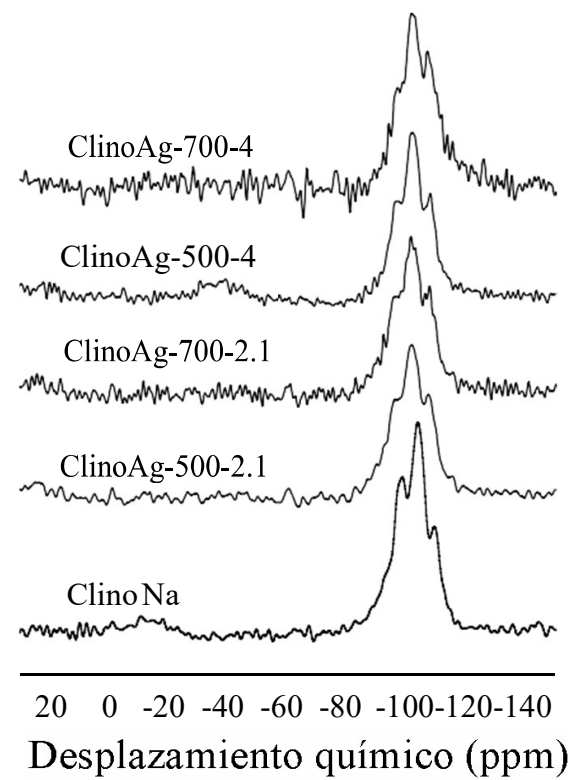

Figura 5.2. Espectros ${ }^{29}$ Si RMN MAS de las muestras ClinoAg-X-Y. 
Los espectros de ${ }^{27}$ AI RMN MAS de las muestras ClinoAg-X-Y, se presentan en la figura 5.3. Independientemente de la cantidad de plata o la temperatura de reducción, los espectros muestran un pico de resonancia cercano a 54 ppm, correspondiente a átomos de aluminio en coordinación tetraédrica (formando parte de la estructura zeolitica). Se observa, sin embargo, que con la presencia de plata y en general con una mayor carga de plata, el pico de resonancia se ensancha ligeramente. Esto se explica debido a que el cuadrupolo de los núcleos de aluminio detecta una mayor densidad electrónica proveniente de las partículas de plata. Estos resultados sugieren que a altos contenidos de plata, algunas partículas de $\mathrm{Ag}$ se incorporan en los microporos y algunas otras se aglomeran en los espacios libres entre las partículas de zeolita.

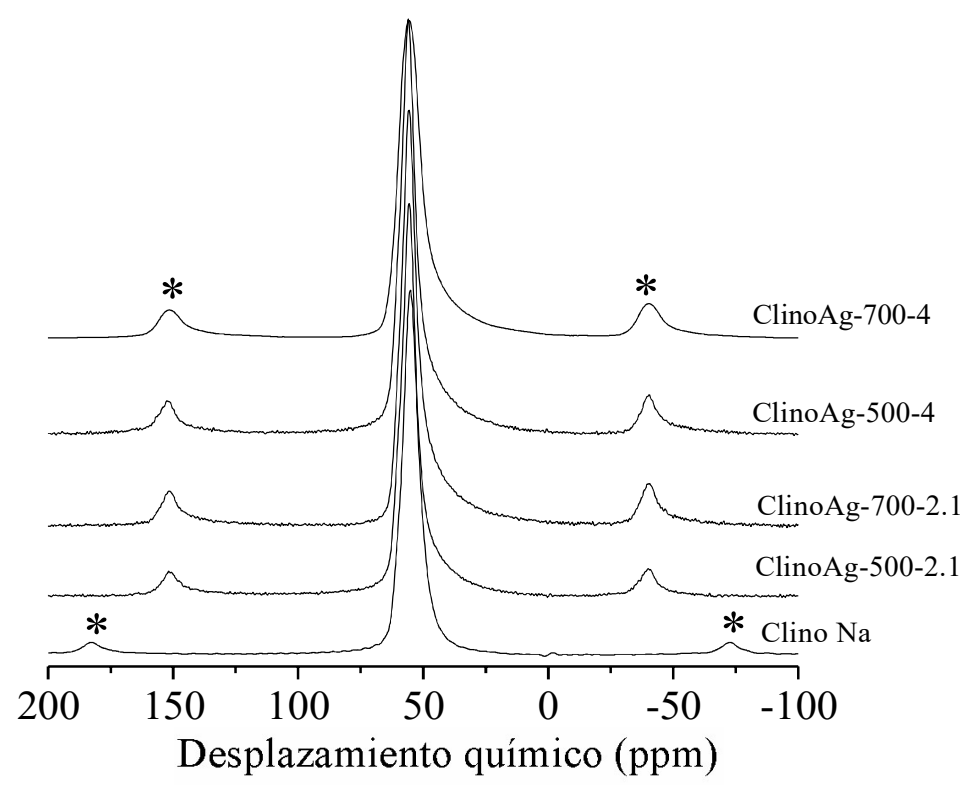

Figura 5.3. Espectros ${ }^{27}$ Al RMN MAS de las muestras ClinoAg-X-Y.*indica bandas de rotación. 
5.1.1.1.2 FaujaAg-500-2.1

El difractograma de rayos $X$ de la muestra FaujaAg-500-2.1, figura 5.4, muestra los picos correspondientes a la zeolita faujacita-Y (tarjeta JCPDS45- 0112). Los picos son intensos y estrechos lo que demuestra la alta cristalinidad de este material. Además de los picos característicos de la zeolita, se observan dos picos a $38.1^{\circ}$ y $44.3^{\circ}$ que corresponden a la plata metálica. Este resultado sugiere que parte de la plata se estabilizó sobre la superficie externa de la zeolita como partículas de plata metálica.

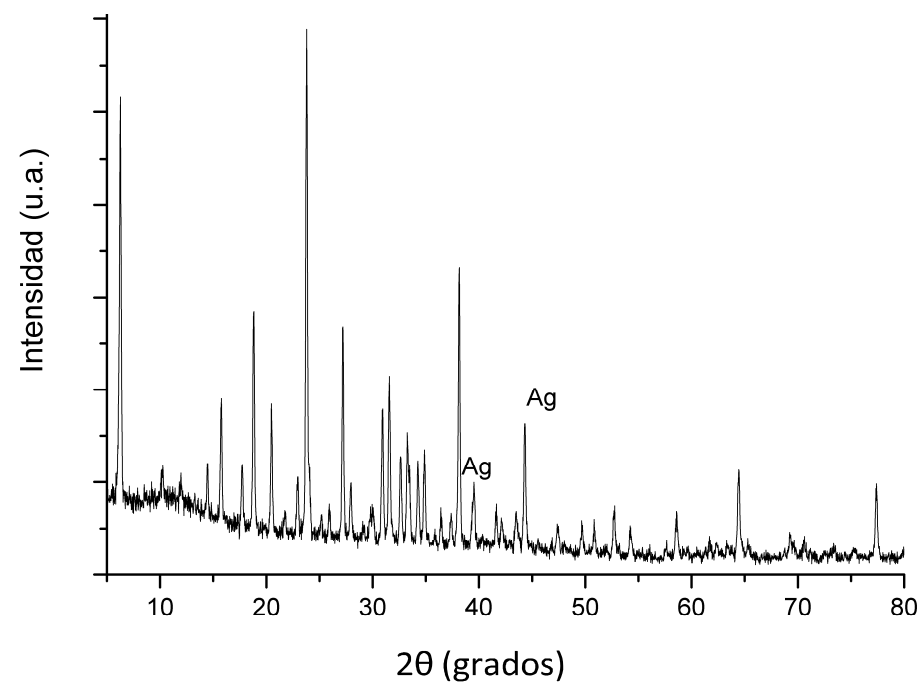

Figura 5.4. Patrones de difracción de rayos $X$ de la muestra FaujaAg-500-2.1.

La figura 5.5 presenta el espectro ${ }^{29} \mathrm{Si}$ RMN MAS de la muestra FaujaAg500-2.1. El espectro se compone de 3 señales con desplazamientos químicos en -86, -93 y -106 ppm, que corresponden a unidades $Q^{4}$ de silicio del tipoSi(2Al), $\mathrm{Si}(1 \mathrm{Al})$ y $\mathrm{Si}(\mathrm{OAl})$, respectivamente. Las señales más intensas son las de $\mathrm{Si}(2 \mathrm{Al})$ y $\mathrm{Si}(1 \mathrm{Al})$, sugiriendo que el aluminio se encuentra homogéneamente distribuido en la red de silicio y que no se presentan dominios enriquecidos en aluminio (Si(4Al)). No obstante, el espectro ${ }^{27} \mathrm{Al}$ RMN MAS (figura 5.6) muestra que no todo el aluminio está incorporado a la red zeolítica. En efecto, en el espectro se observa un pico a $57 \mathrm{ppm}$, el cual es característico de aluminio en coordinación tetraédrica, es decir que forma parte de la estructura zeolítica, como en el caso de la muestra 


\section{Capítulo 5}

sin plata; sin embargo,cuando está presente la plata, también se observa una señal en 0 ppm, que se atribuye a aluminios en coordinación octaédrica. Estas especies generalmente forman parte de una alúmina que algunas veces es parte de la zeolita y le da estabilización (alúmina detrital). En el espectro de la zeolita sin plata, esta señal no se observó, por tanto debe concluirseque la zeolita se desaluminó durante el proceso de deposición de la plata o por el tratamiento térmico.

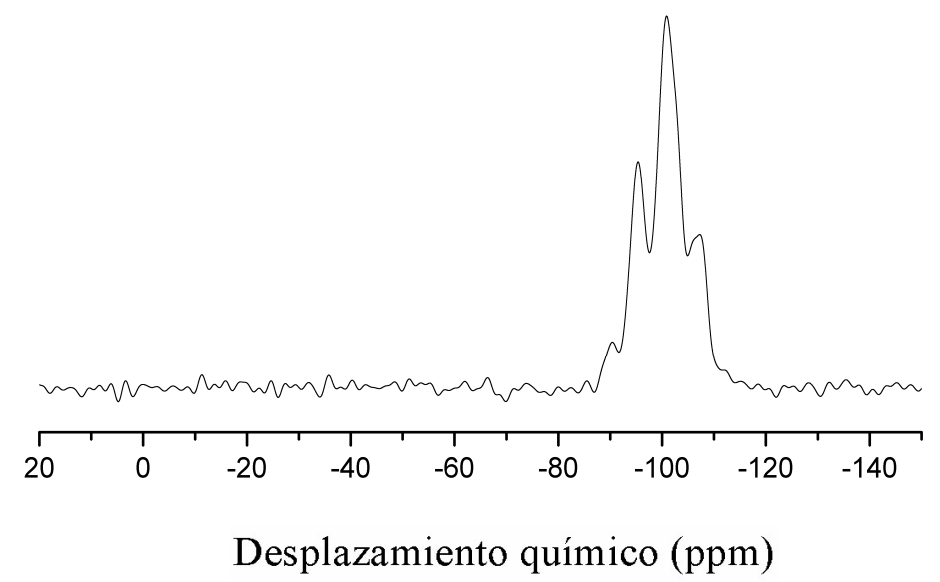

Figura 5.5. Espectro ${ }^{29}$ Si RMN MAS de la muestra FaujaAg-500-2.1.

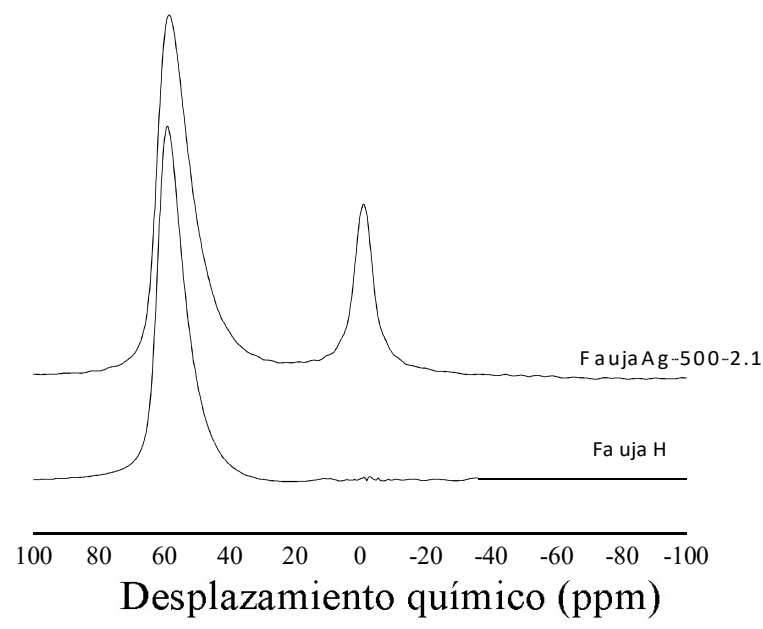

Figura 5.6. Espectro ${ }^{27}$ Al RMN MAS de las muestrasFauja H y FaujaAg-500-2.1. 


\subsection{SilicAg-500-0.11}

El patrón de difracción de rayos X de la muestra SilicAg-500-0.11 (Figura 5.7) se indexa al de la silicalita. La muestra fue cristalina y no se detectó material amorfo. Adicionalmente, no se observaron los picos de la plata metálica, lo que se puede interpretar como una buena dispersión de las partículas de plata sobre la superficie de la silicalita, o bien que el bajo contenido de plata en la muestra está por debajo de la sensibilidad de la técnica DRX.

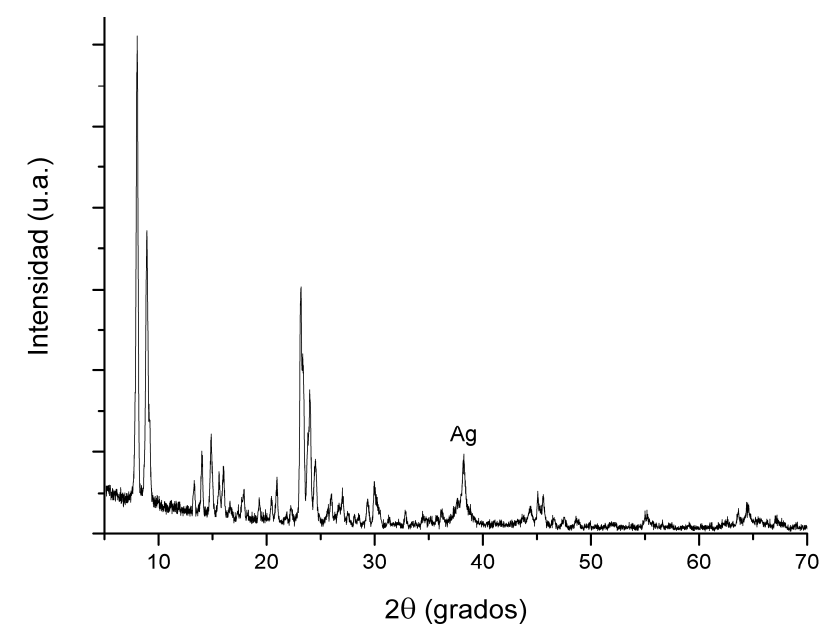

Figura 5.7. Patrón de difracción de rayos $X$ de la muestra SilicAg-500-0.11.

El espectro ${ }^{29}$ Si RMN MAS de la muestra Silic (figura 5.8) se compone de dos señales a -115 y a -117.3 ppm, que revelan unaestructuramuy ordenada. Estos picos no se resuelvenlo suficiente como para asignarlos a los diferentes sitios Th de la estructura de la silicalita. Sin embargo, la presencia del pico intensoa -115 ppm sugiere que la muestra contiene una alta densidad de grupos silanol (-Si-OH), como unidades $\mathrm{Q}^{3}$. Con la incorporación de plata, el espectro no cambia significativamente, a alto campo aparece aún como un hombro. La estructura silicea se mantiene.

Este resultado es relevante ya que puede interpretarse como que la incorporación de plata no modifica la superficie de silanoles. 


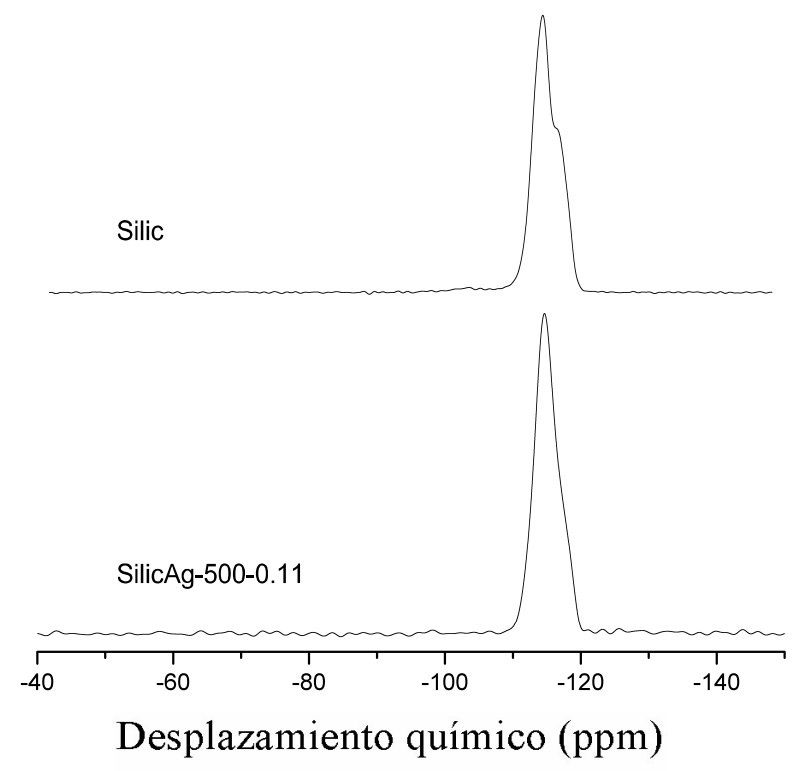

Figura 5.8. Espectro ${ }^{29}$ Si RMN MAS de las muestrasSilic y SilicAg-500-0.11.

\subsubsection{Soportes-Au}

\subsection{ClinoAu-500-2.5}

La figura 5.9 presenta el difractograma de RX de la muestra ClinoAu-5002.5. Todos los picos corresponden a la estructura de la clinoptilolita (tarjeta JCPDS 47-1870). Los picos de la clinoptilolita son intensos y los picos debidos a oro metálico (en $38.1^{\circ}$ y $44.5^{\circ}$ ) son casi imperceptibles. Esto sugiere que el oro está bien dispersado sobre la superficie de la zeolita. Este resultado difiere del observado en la zeolita clinoptilolita con plata, que para contenidos similares de metal, se observaron picos muy intensos debidos a plata metálica. Entonces, debe concluirse, que sobre este soporte, con los métodos utilizados de impregnación, el oro se dispersó mejor que la plata. 


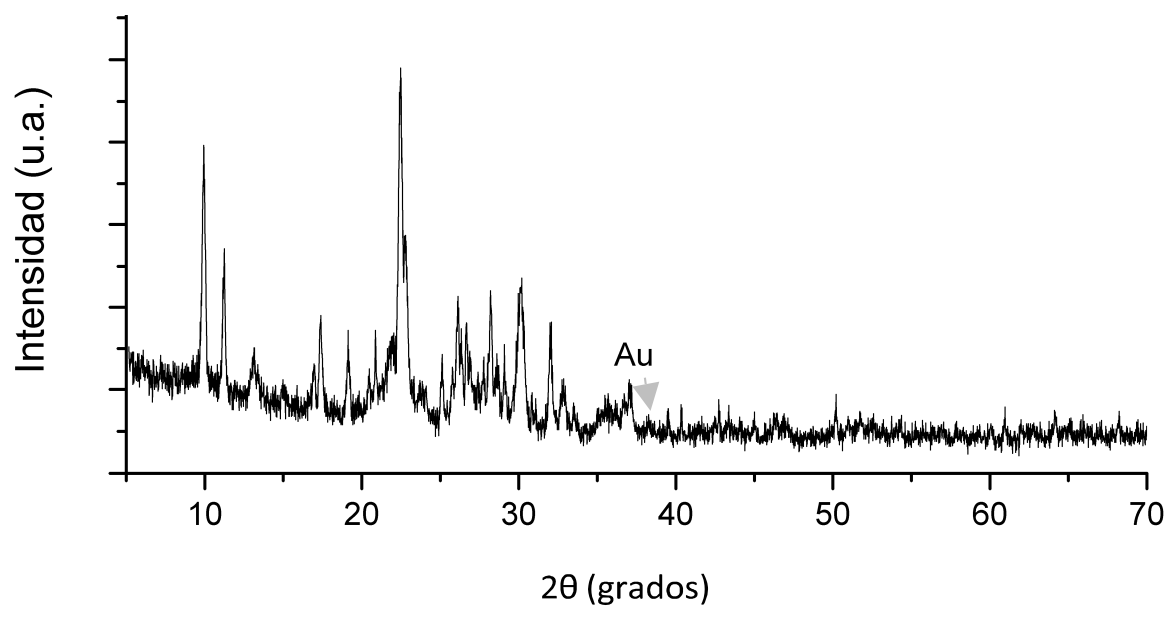

Figura 5.9. Patrón de difracción de rayos $X$ de la muestra ClinoAu-500-2.5.

\subsection{FaujaAu-500-2.5}

El patrón de difracción de rayos $X$ de FaujaAu-500-2.5 se incluye en la figura 5.10. El patrón se indexa completamente al de una zeolita faujasita. Los picos de oro a 38.1 y 44.5 no son perceptibles, sugiriendo una excelente dispersión de esta fase metálica sobre la superficie zeolítica. Si se compara este difractograma con el de la zeolita $Y$ con plata, difieren notablemente en intensidades relativas de los picos. Además, para contenidos similares de metal, los picos de la plata sí se observaron en el difractograma correspondiente. Debido al método de incorporación de los metales, es posible que una fracción de plata se haya incorporado como catión en posición de intercambio, de ahí que las intensidades relativas en el difractograma de FaujaAg-500-2.1 no sean las mismas que en el de FaujaAu-5002.5. En resumen, el oro metálico está mejor dispersado que la plata metálica en la superficie externa del soporte de tipo faujasita. 


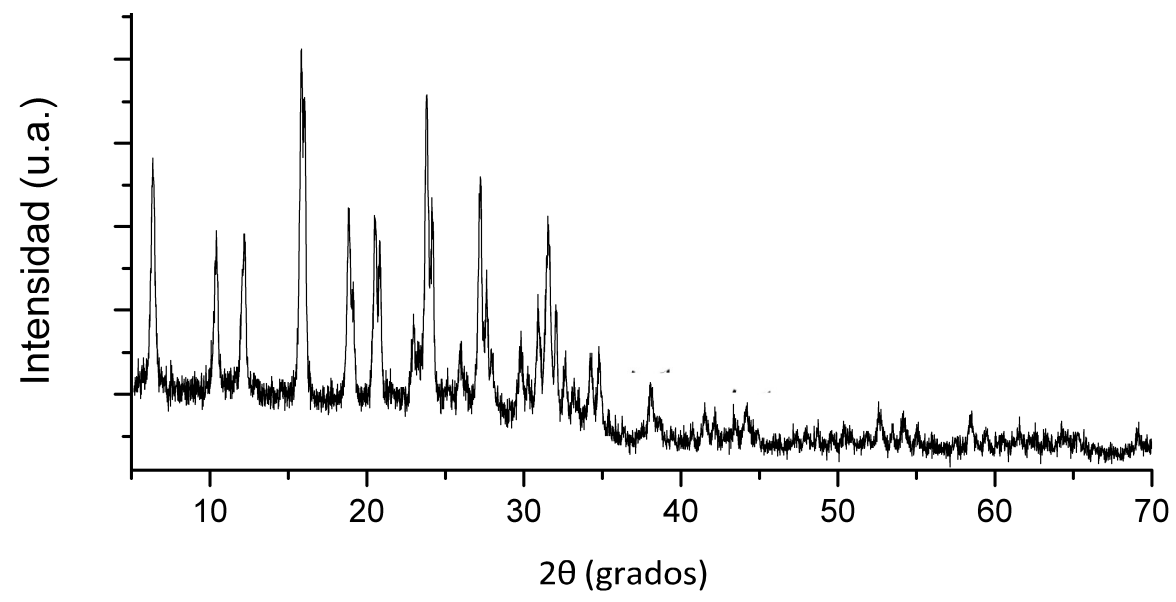

Figura 5.10. Patrón de difracción de rayos $X$ de la muestra FaujaAu-500-2.5.

El espectro ${ }^{29}$ Si RMN MAS de la muestra FaujaAu-500-2.5 (figura 5.11) contiene picos RMN en la ventana de -105 a -120 ppm. Tres picos pueden resolverse a-100, -106 y -111 ppm, atribuibles a unidades de silicio $\mathrm{Si}(3 \mathrm{Al}), \mathrm{Si}(2 \mathrm{Al})$ y $\mathrm{Si}(1 \mathrm{Al})$, respectivamente. Las intensidades relativas de estas señales difieren de las observadas en el espectro correspondiente para la muestra FaujaAg-500-2.1, lo cual confirma no solo que la plata y el oro se dispersan diferentemente en este soporte sino que además las unidades estructurales de la zeolita se modifican. En este sentido, el proceso de impregnación sugiere una redistribución de los aluminios en la red zeolítica, mientras que en la muestra con plata existen mayoritariamente unidades $\mathrm{Si}(1 \mathrm{Al})$, en la muestra con oro las unidades predominantes son $\mathrm{Si}(2 \mathrm{Al})$. Este comportamiento debe estar condicionado por la cantidad de aluminio en la red zeolítica. 


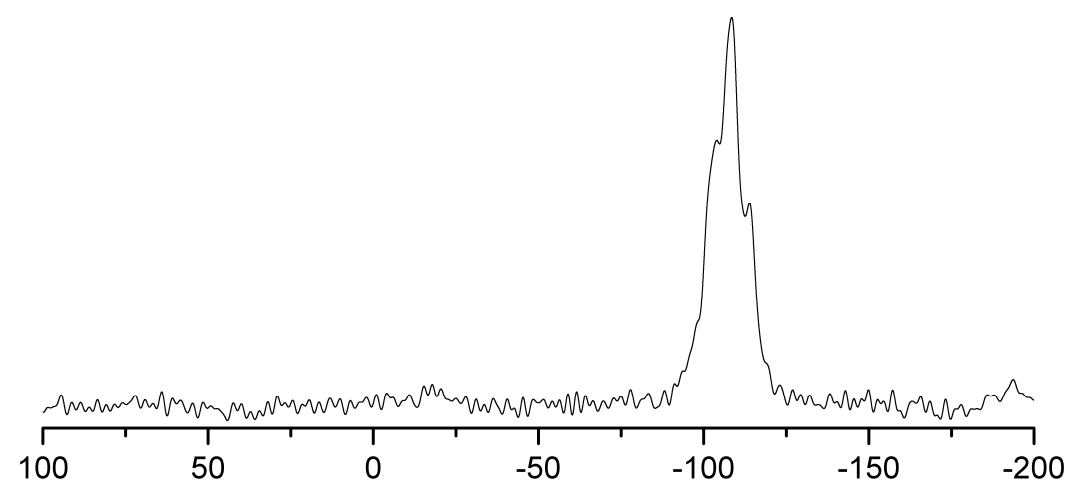

Desplazamiento químico (ppm)

Figura 5.11. Espectro ${ }^{29}$ Si RMN MAS de la muestra FaujaAu-500-2.5.

Siguiendo con la distribución de metales y cationes en la zeolita faujasita, la figura 5.12 muestra el espectro ${ }^{27}$ AI RMN MAS de la muestra FaujaAu-500-2.5. Una señal muy intensa a 57 ppm revela que prácticamente todo el aluminio se mantiene incorporado en la estructura de la zeolita, aun después de incorporado el oro. Además una señal muy poco intensa a 0 ppm sugiere que una pequeña cantidad de alúmina detrital pudiera estar presente. Cabe mencionar que en el caso del espectro de muestra faujasita con plata se observó esta señal a 0 ppm más intensa, sugiriendo una desaluminación, pero en el caso de la muestra con oro no ocurrió este fenómeno.

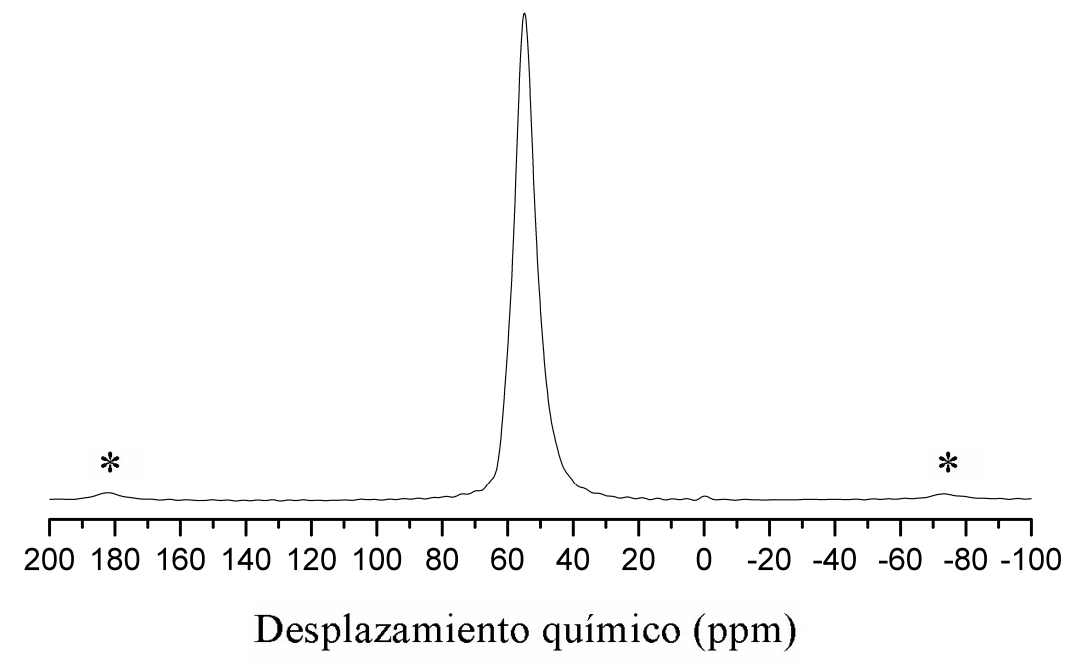

Figura 5.12. Espectro ${ }^{27}$ Al RMN MAS de la muestra FaujaAu-500-2.5, * indica bandas de rotación. 


\subsection{SilicAu-500-0.11}

La figura 5.13 presenta el espectro ${ }^{29}$ Si RMN MAS de la muestra SilicAu- 5000.11. Nuevamente, al igual que la muestra SilicAg-500-0.11, el espectro se compone de una señal muy intensa a -115 ppm y de otra que se resuelve como un hombro a -117 ppm. Si se compara al espectro con el de la muestra sin oro, no se observan cambios significativos, lo que sugiere que no hay cambios estructurales en la red de silicio como consecuencia de la incorporación de oro.

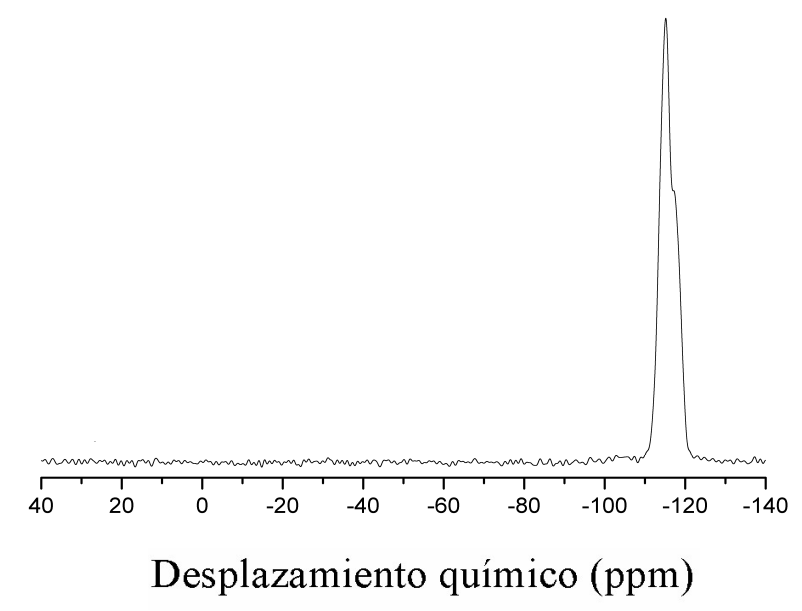

Figura 5.13. Espectro ${ }^{29}$ Si RMN MAS de la muestra SilicAu-500-0.11.

\subsection{MordeAu-500-1.7 y MordeAu-500-2.9}

Los patrones DRX en la figura 5.14 muestran que, al aumentar la cantidad de oro, la cristalinidad de la muestra disminuye. Los picos DRX de oro metálico $\left(38.4^{\circ}\right.$ y $44.5^{\circ}$ ) se observan en el patrón de las dos zeolitas MordeAu-500-1.7 y MordeAu500-2.9. Se debe concluir que la incorporación de oro en la mordenita se acompaña de una destrucción parcial de la red zeolítica y de la estabilización de partículas metálicas de oro grandes en la superficie externa. 


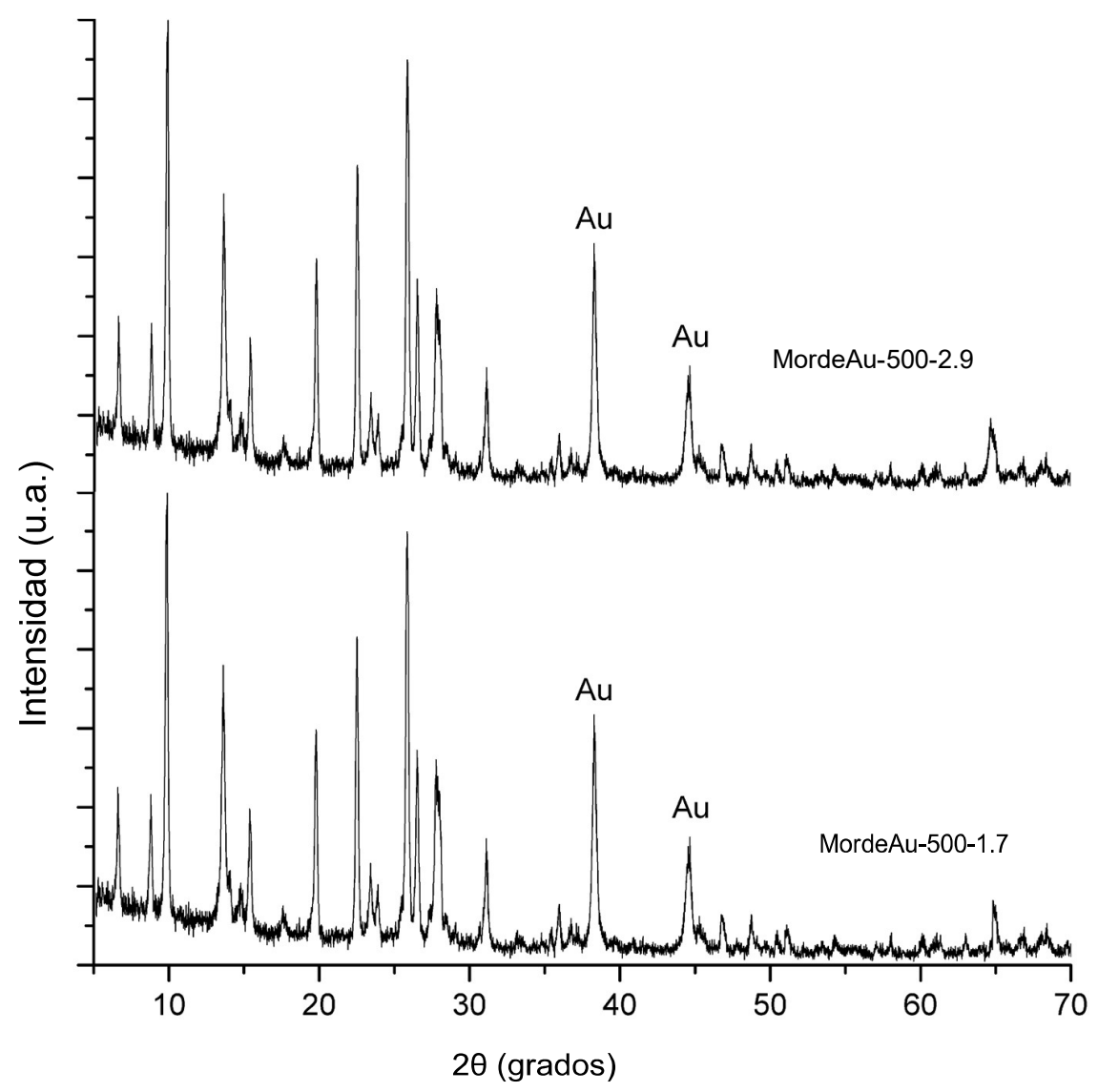

Figura 5.14. Patrón de difracción de rayos X de las muestras MordeAu-500-1.7 y MordeAu-500-2.9.

Los espectros ${ }^{29} \mathrm{Si}{ }^{27} \mathrm{AI}$ RMN MAS de la muestra MordeAu-500-1.7, figuras 5.15 y 5.16 , respectivamente, muestran que la zeolita mordenita, en efecto presenta cambios estructurales como lo sugirió la difracción de rayos X. Por un lado, el espectro ${ }^{29} \mathrm{Si}$ RMN MAS se compone de dos señales con desplazamientos químicos a altos campos (-106 y -114 ppm), lo que sugiere una red deficiente en aluminio. Por otro lado, el espectro ${ }^{27} \mathrm{AI}$ RMN MAS se compone de una sola señal de especies aluminio tetraédricas (a $54.8 \mathrm{ppm}$ ). No obstante, la señal es ancha y asimétrica, lo que sugiere que algunas partículas de oro, probablemente iones, están cerca de los aluminios estructurales, es decir dentro de los canales de la zeolita. 


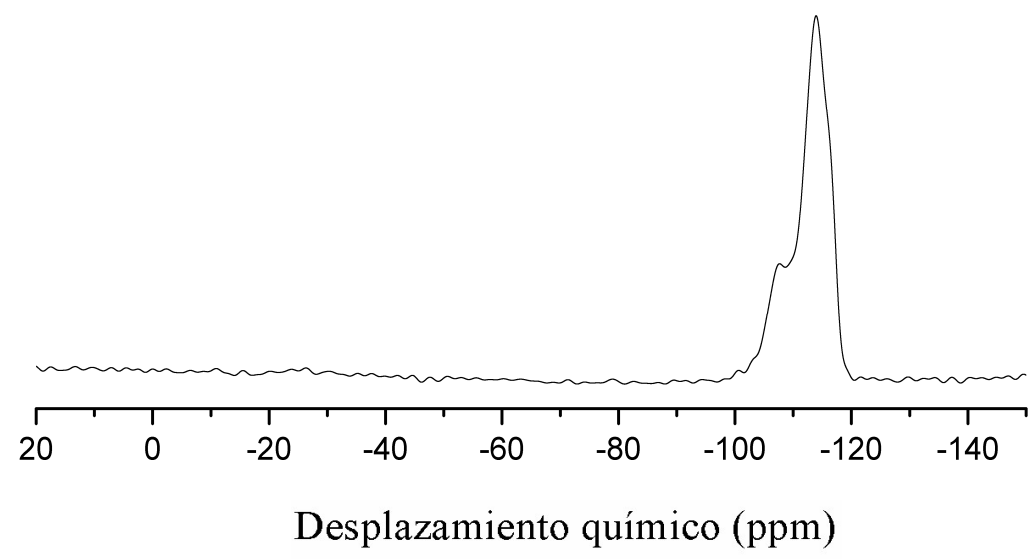

Figura 5.15. Espectro ${ }^{29}$ Si RMN MAS de la muestra MordeAu-500-1.7.

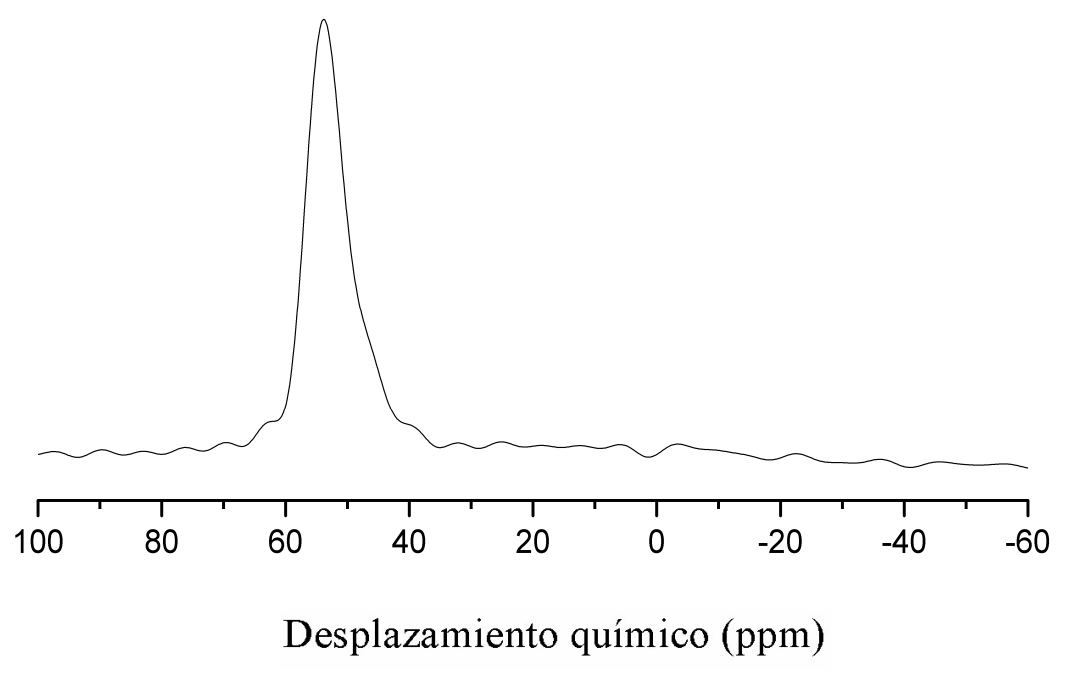

Figura 5.16. Espectro ${ }^{27}$ Al RMN MAS de la muestra MordeAu-500-1.7.

\subsubsection{Propiedades texturales}

\subsubsection{Soportes-Ag}

De la caracterización estructural de la serie de materiales con plata, quedó establecido que el tipo de zeolita tiene una influencia significativa en la fase de plata y la estabilidad del sistema plata-zeolita. Particularmente, debe resaltarse la baja estabilidad estructural del sistema faujasita-Ag.

Las diferencias estructurales deberían verse reflejadas en las propiedades texturales. En este sentido, en la figura 5.17 se comparan las curvas de Kratky de cuatro muestras de ClinoAg-X-Y, todas ellas presentan el perfil típico de 
heterogeneidades globulares. Por supuesto, los objetos que dispersan fueron las partículas metálicas. De este modo, las partículas esféricas de plata fueron depositadas sobre el soporte de zeolita.

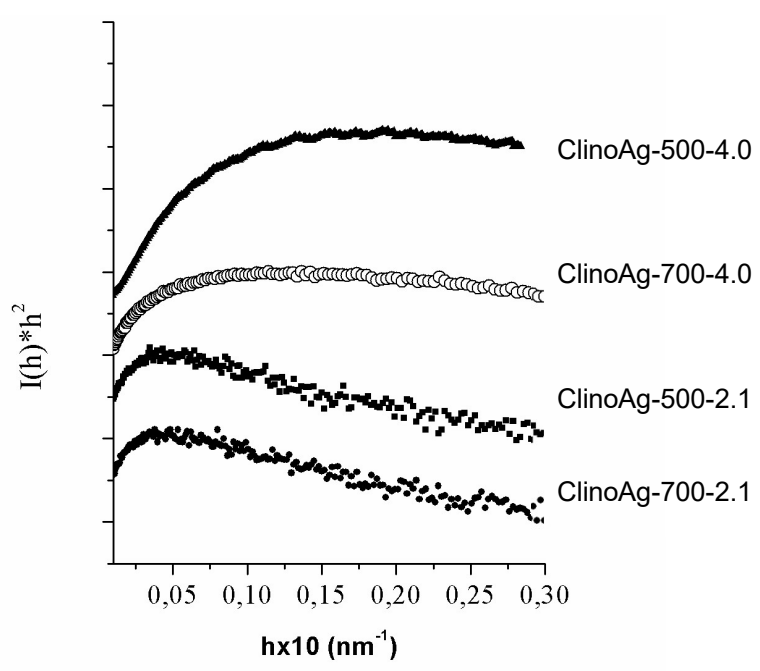

Figura 5.17. Perfiles Kratky para las muestras ClinoAg-X-Y.

Las partículas de plata, en los otros soportes también fueron esféricas, con la excepción de la SilicAg-500-0.11 en donde el perfil de Kratky sugirió partículas fibrosas. Esto puede interpretarse como aglomerados de partículas globulares formando arreglos cilíndricos en la superficie del soporte Silic.

La distribución de tamaño de las partículas se calculó por microscopía electrónica de transmisión (MET). En la figura 5.18 se muestran los histogramas de las muestras de clinoptilolita preparadas con diferentes cantidades de $\mathrm{Ag}$ y a diferentes temperaturas de reducción. En la muestra reducida a $500^{\circ} \mathrm{C}$ con la menor cantidad de plata se obtuvo una distribución multimodal observándose partículas de 3 hasta $15 \mathrm{~nm}$, con la mayor parte de las partículas de $12.5 \mathrm{~nm}$ de diámetro. Cuando la temperatura de reducción fue $700^{\circ} \mathrm{C}$ se observaron partículas de 3 hasta $20 \mathrm{~nm}$, predominando partículas de 7.5, 10y $15 \mathrm{~nm}$ (diámetro). De los histogramas de distribución de tamaño se percibe que el tamaño de las partículas es dependiente del contenido de Ag y la temperatura de reducción. Un aumento en la concentración de metal genera partículas más grandes. En las muestras 
reducidas a $500^{\circ} \mathrm{C}$ el diámetro de partícula predominante aumenta de 12.5 a $17.5 \mathrm{~nm}$ aumentando el contenido de $\mathrm{Ag}$ de 2.1 a $4.0 \%$. Para las muestras reducidas a $700^{\circ} \mathrm{C}$ el diámetro de partícula más probable aumenta de $15 \mathrm{~nm}$ a $17.5 \mathrm{~nm}$. Con el aumento de la temperature de reducción se observa un incremento en el tamaño de las partículas. Incluso, en la muestra ClinoAg-700-4.0 la alta temperature de reducción y alto contenido de plata, combinados, provocan una distribución más heterogénea de las partículas grandes que se forman.
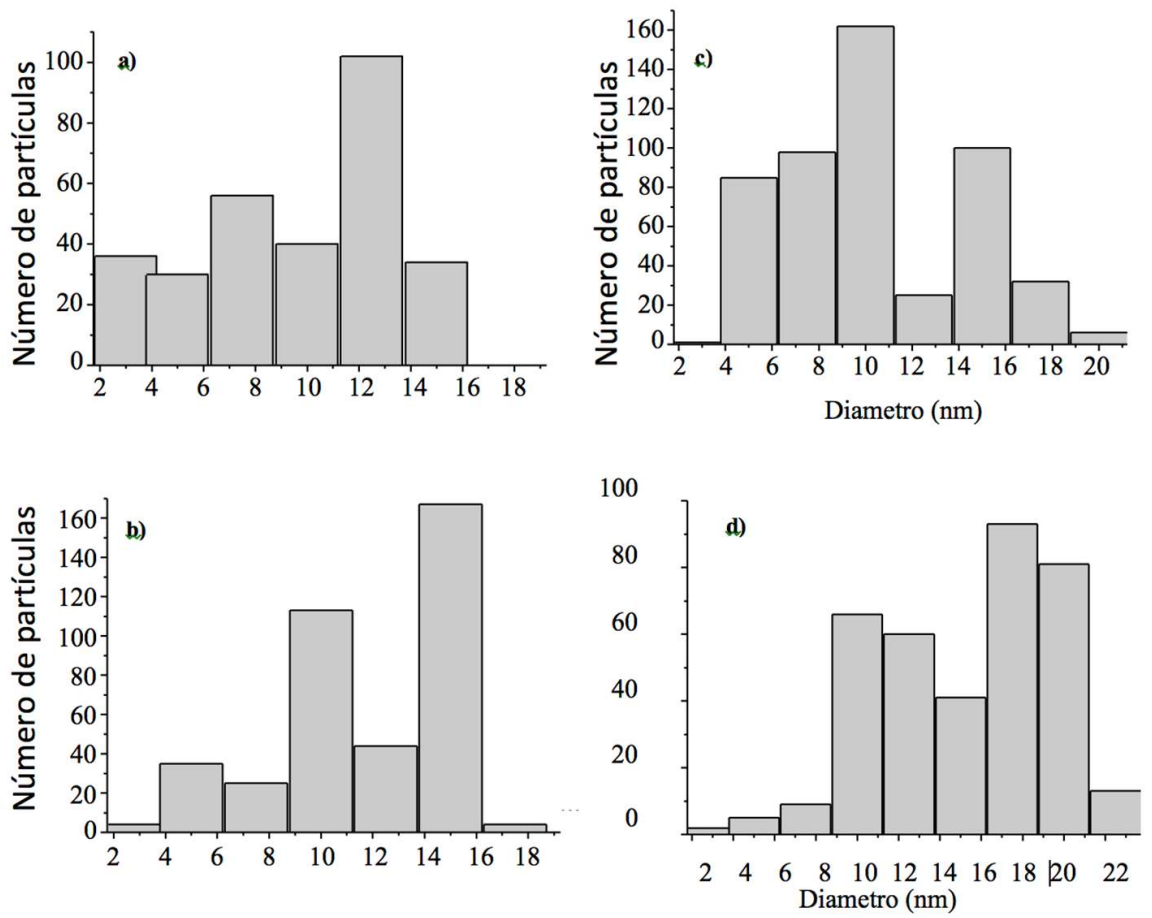

Figura 5.18 Histogramas de distribución de tamaño de partícula de ClinoAg-X-Y: a) ClinoAg-500- 2.1 b) ClinoAg-500-4.0 c) ClinoAg-700-2.1 y d) ClinoAg-700-4.0.

En las figuras 5.19 y 5.20 se reportan los tamaños de partículas de las muestras FaujaAg-500-2.1 y SilicAg-500-0.11, respectivamente. En ambas muestras se obtuvo una distribución multimodal, observándose partículas de 3 hasta $27.5 \mathrm{~nm}$, con la mayor parte de las partículas en el intervalo de 12.5 a $17.5 \mathrm{~nm}$ (diámetro) para la FaujaAg-500-2.1 y en el intervalo de 10 a $15 \mathrm{~nm}$ para la SilicAg-500-0.11.Comparando el tamaño de las partículas en ambos materiales, se observa que la SilicAg-500-0.11 presenta mayor 
cantidad de partículas de tamaño de 10 a $12.5 \mathrm{~nm}$.

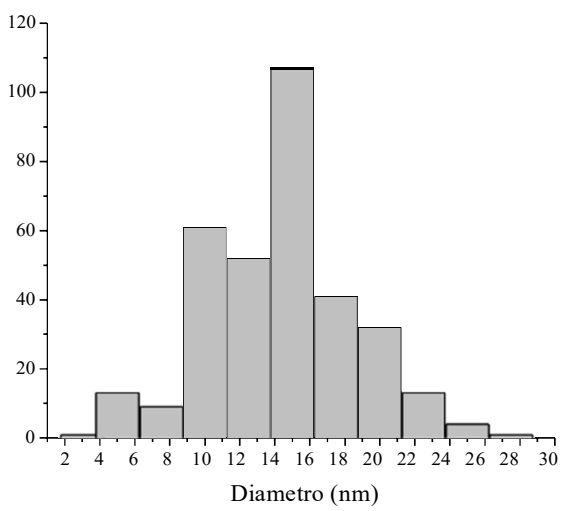

Figura 5.19 Histogramas de distribución de tamaño de partícula de FaujaAg-500-2.1.

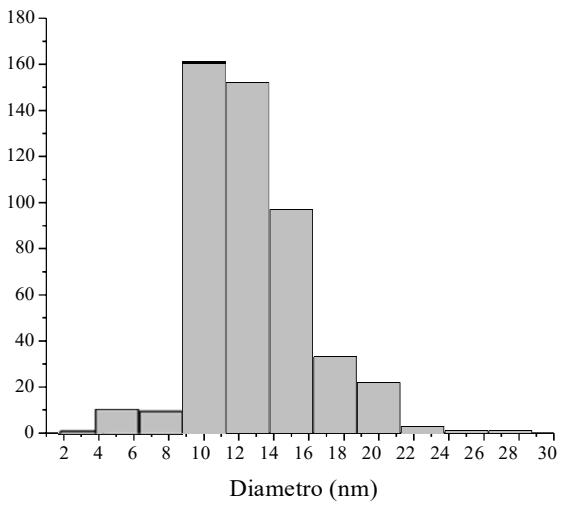

Figura 5.20 Histogramas de distribución de tamaño de partícula de SilicAg-500-0.11.

Siguiendo con las propiedades texturales de las muestras soporte-Ag, susvalores de área específica se presentan en la tabla 5.1. Como se observa, los materiales con plata reducen su área específica cuando la plata se incorpora al soporte. Las áreas específicas dependen del contenido de plata, presentado el valor más alto de área específica el material SilicAg-500-0.11 $\left(397 \mathrm{~m}^{2} / \mathrm{g}\right)$, el cual contiene la menor cantidad de Ag. 
Tabla 5.1. Áreas especificas de los materiales soporte-Ag.

\begin{tabular}{|l|c|l|c|}
\hline \multicolumn{1}{|c|}{ Muestra } & $\begin{array}{c}\text { Área específica } \\
\left(\mathrm{m}^{2} / \mathrm{g}\right)\end{array}$ & \multicolumn{1}{|c|}{ Muestra } & $\begin{array}{c}\text { Área específica } \\
\left(\mathrm{m}^{2} / \mathrm{g}\right)\end{array}$ \\
\hline ClinoNa & 108 & Fauja & 925 \\
\hline ClinoAg-500-2.1 & 81 & FaujaAg-500-2.1 & 166 \\
\hline ClinoAg-700-2.1 & 53 & Silic & 439 \\
\hline ClinoAg-500-4.0 & 62 & SilicAg-500-0.11 & 397 \\
\hline ClinoAg-700-4.0 & 47 & & \\
\hline
\end{tabular}

Los valores de la dimensión fractal de las partículas de plata en las muestras de soporte-Ag se calcularon a partir de los datos de SAXS y de acuerdo a la ley de Porod (Harrison A.,1995), tabla 5.2.Para la serie de ClinoAg-X-Y se nota que el aumento en la temperatura de reducción induce un incremento en la dimensión fractal, revelando un incremento en el tamaño de las partículas y en su densidad (relación área/volumen). No obstante, debe hacerse notar que para una misma temperatura de reducción, la dimensión fractal varía según el soporte utilizado. Las partículas de plata en SilicAg-500-0.11 son más rugosas que las de ClinoAg-5002.1 y ClinoAg-700-4.0.

Tabla 5.2. Dimensión fractal de las muestras soporte-Ag, determinada por SAXS.

\begin{tabular}{|c|c|}
\hline Muestra & Dimensión Fractal \\
\hline ClinoAg-500-2.1 & 2.33 \\
\hline ClinoAg-700-2.1 & 2.69 \\
\hline ClinoAg-500-4.0 & 2.35 \\
\hline ClinoAg-700-4.0 & 2.91 \\
\hline FaujaAg-500-2.1 & 2.68 \\
\hline SilicAg-500-0.11 & 2.55 \\
\hline
\end{tabular}

\subsubsection{Soportes-Au}

La caracterización por SAXS de los soportes-Au reveló una tendencia similar que la observada en los soportes-Ag, es decir, los objetos que dispersaron fueron de forma esférica para ClinoAu-500-2.5, MordeAu-500-1.7, MordeAu-5002.9 y FaujaAu-500-2.5, mientras que para SilicAu-500-0.11 fueron fibrosas. Los tamaños de las partículas de $\mathrm{Au}$ en los diferentes soportes se reportan como histograma en la figura 5.21. 
Capítulo 5
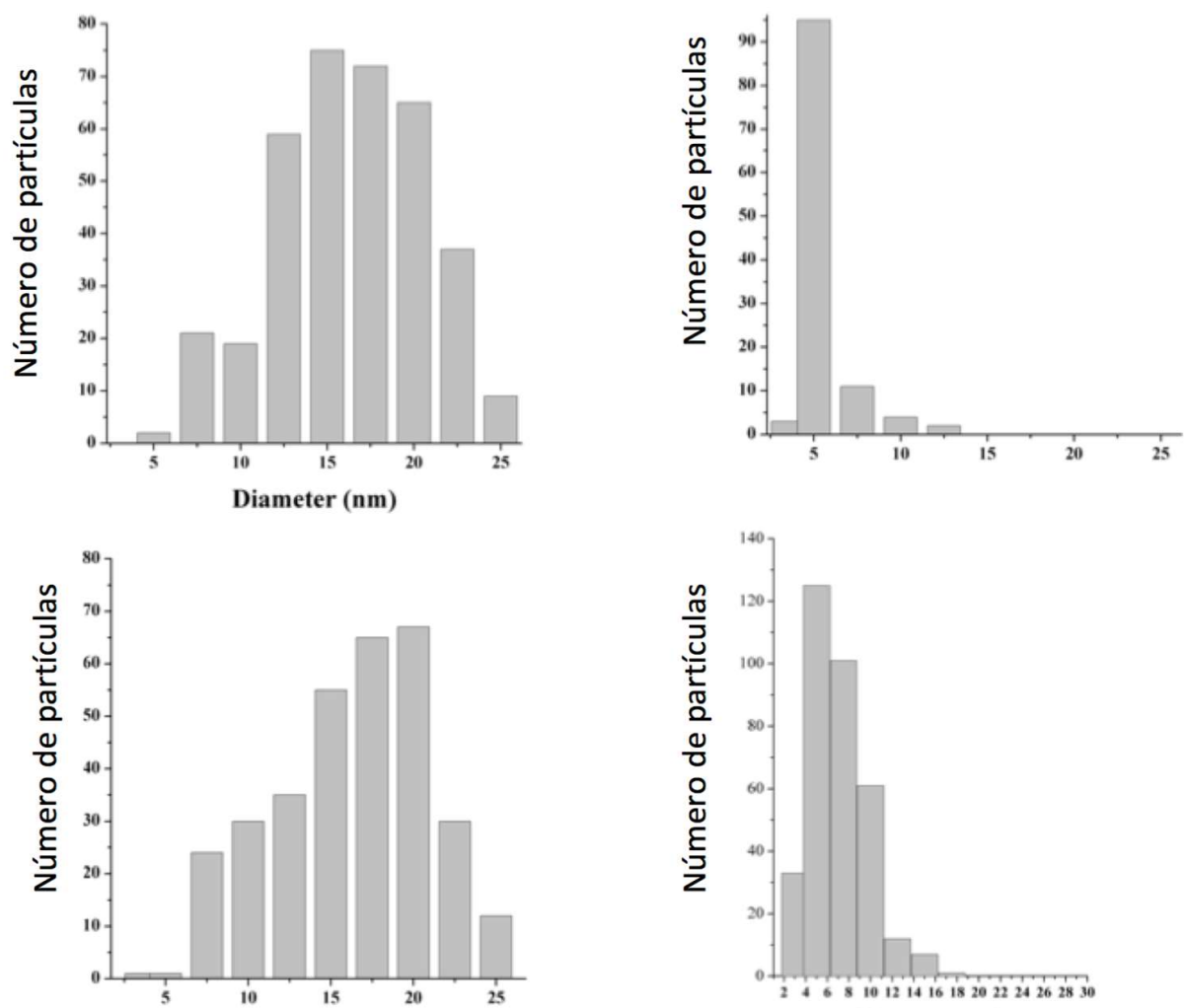

Figura 5.21 Histogramas de distribución de tamaño de partícula de a) ClinoAu-500-2.5 b) MordeAu500-1.7 c) FaujaAu-500-2.5 y d) SilicAu-500-0.11.

Claramente, el soporte marca un efecto en el tamaño de las partículas estabilizadas. Los materiales FaujaAu-500-2.5 y SilicAu-500-0.11 son evidentemente los que estabilizan las partículas más pequeñas, es más, de entre estos materiales, la zeolita faujasita tiene la distribución más homogénea de tamaños de partículas de oro, casi exhibe una distribución monomodal en $5 \mathrm{~nm}$. En contraste, en los materiales ClinoAu-500-2.5, MordeAu-500-1.7 y MordeAu- 5002.9se obtuvo una distribución multimodal, observándose partículas de 3 hasta $25 \mathrm{~nm}$, con la mayor parte de las partículas en el intervalo de 7.5 a $20 \mathrm{~nm}$ (diámetro) para la ClinoAu-500-2.5 y en el intervalo de 15 a $20 \mathrm{~nm}$ para MordeAu- 500-Y.

Los valores de área específica de las muestras soporte-Au se presentan en la tabla 5.3. Al igual que los materiales con plata, los materiales con oro reducen 
su área específica cuando el oro se incorpora al soporte. Las áreas específicas de los materiales están influenciadas por el contenido de oro. El material SilicAu-500$0.11\left(418 \mathrm{~m}^{2} / \mathrm{g}\right)$, conla menor cantidad de Au fue el material con más alta área específica.

Tabla 5.3. Características texturales de los materiales soporte-Au.

\begin{tabular}{|c|c|c|}
\hline Muestra & Área específica $\left(\mathrm{m}^{2} / \mathrm{g}\right)^{*}$ & Dimensión Fractal $^{* *}$ \\
\hline ClinoAu-500-2.5 & 88 & 2.3 \\
\hline MordeAu-500-1.7 & 188 & 2.6 \\
\hline MordeAu-500-2.9 & 177 & 2.8 \\
\hline FaujaAu-500-2.5 & 319 & 2.2 \\
\hline SilicAu-500-0.11 & 418 & 2.1 \\
\hline \multicolumn{2}{|c|}{${ }^{*}$ Determinada por adsorción de $\mathrm{N}_{2 .}{ }^{* *}$ Determinada por SAXS. }
\end{tabular}

Los valores de la dimensión fractal de las partículas de oro en las muestras de soporte-Ause calcularon a partir de los datos de SAXS y de acuerdo a la ley de Porod, tabla 5.3. La dimensión fractal, entendida como un parámetro que caracteriza la rugosidad de las partículas de oro, varía como una función del soporte. Las partículas grandes de oro en la mordenita parecen ser densas y rugosas mientras que en la silic, el arreglo en forma de fibras, conduce a partículas "lisas". La clinoptilolita y faujasita estabilizan partículas de rugosidad media.

\subsection{Evaluación de materiales como bactericidas}

\subsubsection{Ensayo de concentraciones mínimas Inhibitorias para materiales soporte-Ag como biocida de E. Coli.}

Se realizó un primer sondeo para determinar la concentración minima inhibitoria (CMI) de los materiales soporte-Ag como biocida de E. coli. En el ensayo se incluyeron 4 aislados de $E$. coli, los que fueron expuestos a los materiales soporte-Ag para obtener suspensiones con concentraciones (gramos de material por mililitro de caldo de cultivo) de $2.2 \times 10^{-3} \mathrm{~g} / \mathrm{mL}, 3.3 \times 10^{-3} \mathrm{~g} / \mathrm{mL}$ y $4.4 \times 10^{-3} \mathrm{~g} / \mathrm{mL}$; después de la incubación por $72 \mathrm{~h}$ se determinó el poder inhibitorio de los materiales soporte-Ag. Finalizado el tiempo de incubación, se obtuvieron los resultados de las pruebas que se presentan en la tabla 5.3. En este primer 
sondeo, la cepa E. coli mostró crecimiento frente a los materiales ClinoAg-700-2.1 y ClinoAg-500-2.1, indicando una tolerancia a concentraciones de $4.4 \times 10^{-3} \mathrm{~g} / \mathrm{mL}$ para estos materiales. Por otra parte, los materiales ClinoAg-700-4.0, ClinoAg- 5002.1 y FaujaAg-500-2.1 inhibieron el crecimiento de E. coli a concentraciones de 3.3 $\times 10^{-3} \mathrm{~g} / \mathrm{mL}$. Con el material SilicAg-500-0.11, la E. coli no presentó inhibición de crecimiento a una concentración de $4.4 \times 10^{-3} \mathrm{~g} / \mathrm{mL}$. A partir de estos resultados, fue posible plantear un segundo sondeo para encontrar la concentración mínima inhibitoria de $E$. coli frente a los materiales ClinoAg-700-2.1 y ClinoAg-500-2.1. En el segundo barrido se utilizaron concentraciones de $5.5 \times 10^{-3} \mathrm{~g} / \mathrm{mL}, 6.6 \times 10^{-3} \mathrm{~g} / \mathrm{mL}$, y $7.7 \times 10^{-3} \mathrm{~g} / \mathrm{mL}$ (Tabla 5.4); después de la incubación se determinó la inhibición de la E. coliparalos materiales soporte-Ag adiferentes concentraciones. Se observó una inhibición del crecimiento de $E$. coli frente a los materiales ClinoAg-700-2.1 y ClinoAg-500-2.1 a una concentración de $5.5 \times 10^{-3} \mathrm{~g} / \mathrm{mL}$. En los ensayos con ClinoAg-X-Y, se detectó que la efectividad de los materiales para inhibir el crecimiento de E. coli fue dependiente de la concentración de Ag.El tipo de soporte fue otro parámetro relevante en la efectividad de los materiales para inhibir el crecimiento de E. coli. Se logró la inhibición de E. coli con materiales que contenían incluso una baja concentración de Ag, como fue el caso de FaujaAg-500-2.1que contenía una concentración menor que los materiales ClinoAg-500-4.0 y ClinoAg700-4.0.

Tabla 5.4. Concentraciones mínimas inhibitorias de los materiales soporte-Ag paraE. coli.

\begin{tabular}{|c|c|c|c|c|c|c|c|c|}
\hline $\begin{array}{c}\text { Cepa/ Material } \\
\text { biocida }\end{array}$ & $\begin{array}{c}\text { Control } \\
1\end{array}$ & $\begin{array}{c}2.2 \times 10^{-} \\
3 \mathrm{~g} / \mathrm{mL}\end{array}$ & $\begin{array}{c}3.3 \times 10^{-} \\
3 \mathrm{~g} / \mathrm{mL}\end{array}$ & $\begin{array}{c}4.4 \times 10^{-} \\
3 \mathrm{~g} / \mathrm{mL}\end{array}$ & $\begin{array}{c}5.5 \times 10^{-} \\
3 \mathrm{~g} / \mathrm{mL}\end{array}$ & $\begin{array}{c}6.6 \times 10^{-} \\
3 \mathrm{~g} / \mathrm{mL}\end{array}$ & $\begin{array}{c}7.7 \times 10^{-} \\
3 \mathrm{~g} / \mathrm{mL}\end{array}$ & $\begin{array}{c}\text { Control } \\
2\end{array}$ \\
\hline ClinoAg-700-2.1 & + & + & + & + & - & - & - & + \\
\hline ClinoAg-700-4.0 & + & + & - & - & - & - & - & + \\
\hline ClinoAg-500-2.1 & + & + & + & + & - & - & - & + \\
\hline ClinoAg-500-4.0 & + & + & - & - & - & - & - & + \\
\hline FaujaAg-500-2.1 & + & + & - & - & - & - & - & + \\
\hline SilicAg-500-0.11 & + & + & + & - & - & - & - & + \\
\hline
\end{tabular}

5.2.2 Ensayo de CMI para materiales soporte-Ag como biocida de S. typhi

Siguiendo el procedimiento de la sección 5.2.1., 4 aislados de $S$. typhi se expusieron a los materiales soporte-Ag con concentraciones de $2.2 \times 10^{-3} \mathrm{~g} / \mathrm{mL}$, $3.3 \times 10^{-3} \mathrm{~g} / \mathrm{mL}$ y $4.4 \times 10^{-3} \mathrm{~g} / \mathrm{mL}$; después de incubación por $72 \mathrm{~h}$ se determinó el 
poder inhibitorio de los materiales soporte-Ag. En la evaluación del primer sondeo de tubos que contenían concentraciones ascendentes de soporte-Ag se observó que la cepa $S$. typhi presentó crecimiento frente todos los materiales, indicando su tolerancia a concentraciones de $4.4 \times 10^{-3} \mathrm{~g} / \mathrm{mL}$.

En el segundo barrido se utilizaron concentraciones de $5.5 \times 10^{-3} \mathrm{~g} / \mathrm{mL}, 6.6 \mathrm{x}$ $10^{-3} \mathrm{~g} / \mathrm{mL}$, y $7.7 \times 10^{-3} \mathrm{~g} / \mathrm{mL}$; después de la incubación se determinó la inhibición de la S. typhi frente a las concentraciones de los materiales soporte-Ag. Los materiales ClinoAg-700-4.0 y ClinoAg-500-4.0 inhibieron el crecimiento de S. typhi a concentraciones de $6.6 \times 10^{-3} \mathrm{~g} / \mathrm{mL}$. Se observo que cuando los materiales contenían una menor cantidad de plata (ClinoAg-700-2.1 y ClinoAg-500-2.1) su eficiencia como bactericida fue menor, se necesitó una concentración de 7.7 x 10${ }^{3} \mathrm{~g} / \mathrm{mL}$ para inhibir el crecimiento bacteriano.

En el caso de los materiales SilicAg-500-0.11 y FaujaAg-500-2.1, la concentración inhibitoria para $S$. typhi resultó más baja que para los otros materiales, a una concentración de $5.5 \times 10^{-3} \mathrm{~g} / \mathrm{mL}$ se dejó de notar crecimiento bacteriano, por lo que se prosiguió con el cultivo de una muestra de ese tubo y de los demás que siguieron presentando ausencia de turbidez (figura 5.22). Los resultados de los antibiogramas se muestran en la tabla 5.5.

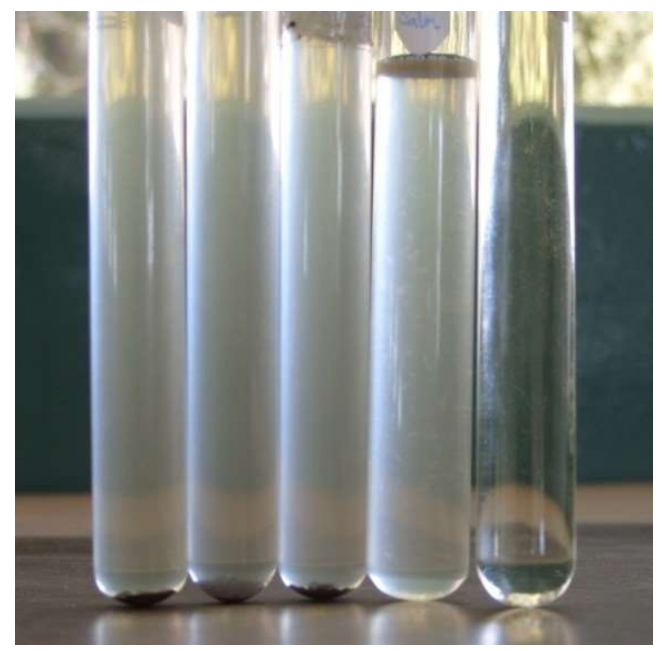

Figura 5.22. Antibiograma en medio liquido de S. typhi frente a ClinoAg-500-4.0a CMIs de: a) $2.2 \times 10^{-3}$, b) $3.3 \times 10^{-3}$, c) $4.4 \times 10^{-3}$, d) $5.5 \times 10^{-3}$ y e) $6.6 \times 10^{-3}$. 
Capítulo 5

Tabla 5.5 Concentraciones mínimas inhibitorias de los materiales soporte-Ag paraS. typhi.

\begin{tabular}{|c|c|c|c|c|c|c|c|c|}
\hline $\begin{array}{c}\text { Cepa/ Material } \\
\text { biocida }\end{array}$ & $\begin{array}{c}\text { Control } \\
1 \\
\end{array}$ & $\begin{array}{c}2.2 \times 10^{-} \\
3 \mathrm{~g} / \mathrm{mL}\end{array}$ & $\begin{array}{c}3.3 \times 10^{-} \\
3 \mathrm{~g} / \mathrm{mL}\end{array}$ & $\begin{array}{c}4.4 \times 10^{-} \\
3 \mathrm{~g} / \mathrm{mL}\end{array}$ & $\begin{array}{c}5.5 \times 10^{-} \\
3 \mathrm{~g} / \mathrm{mL}\end{array}$ & $\begin{array}{c}6.6 \times 10^{-} \\
{ }^{3} \mathrm{~g} / \mathrm{mL}\end{array}$ & $\begin{array}{c}7.7 \times 10^{-} \\
3 \mathrm{~g} / \mathrm{mL}\end{array}$ & $\begin{array}{c}\text { Control } \\
2\end{array}$ \\
\hline ClinoAg-700-2.1 & + & + & + & + & + & + & - & + \\
\hline ClinoAg-700-4.0 & + & + & + & + & + & - & - & + \\
\hline ClinoAg-500-2.1 & + & + & + & + & + & + & - & + \\
\hline ClinoAg-500-4.0 & + & + & + & + & + & - & - & + \\
\hline FaujaAg-500-2.1 & + & + & + & + & - & - & - & + \\
\hline SilicAg-500-0.11 & + & + & + & + & - & - & - & \\
\hline
\end{tabular}

\subsubsection{Ensayo de CMI para materiales soporte-Au como biocida de E.} Coli

Siguiendo con el procedimiento para determinar la CMI, 4 aislados de $E$. coli fueron expuestos a los materiales soporte-Au, se utilizó un intervalo de concentraciones de $2.2 \times 10^{-3} \mathrm{~g} / \mathrm{mL}$ hasta $4.4 \times 10^{-3} \mathrm{~g} / \mathrm{mL}$. En el primer sondeo después de incubación por $72 \mathrm{~h}$, la $E$. coli presentó crecimiento frente a los materiales soporte-Au, a este intervalo se presentó tolerancia para todos los materiales, se planteó un segundo sondeo a concentraciones de $5.5 \times 10^{-3} \mathrm{~g} / \mathrm{mL}, 6.6$ $\times 10^{-3} \mathrm{~g} / \mathrm{mL}$, y $7.7 \times 10^{-3} \mathrm{~g} / \mathrm{mL}$.

En el segundo sondeo para el material ClinoAu-500-2.5, la cepa E. coli presentó crecimiento a concentraciones inferiores a $7.7 \times 10^{-3} \mathrm{~g} / \mathrm{mL}$. En el caso de los materiales SilicAu-500-0.11, FaujaAu-500-2.5, MordeAu-500-1.7 y MordeAu500-2.9 a concentración de $6.6 \times 10^{-3} \mathrm{~g} / \mathrm{mL}$ no se observó crecimiento bacteriano durante la incubación.

En la Tabla 5.6 se reporta la concentración mínima inhibitoria de los materiales soporte-Au para E. coli.

Tabla 5.6. Concentraciones mínimas inhibitorias de los materiales soporte-Au paraE. coli.

\begin{tabular}{|c|c|c|c|c|c|c|c|c|}
\hline $\begin{array}{c}\text { Cepa/ Material } \\
\text { biocida }\end{array}$ & $\begin{array}{c}\text { Control } \\
1\end{array}$ & $\begin{array}{c}2.2 \times 10^{-} \\
3 \mathrm{~g} / \mathrm{mL}\end{array}$ & $\begin{array}{c}3.3 \times 10^{-} \\
3 \mathrm{~g} / \mathrm{mL}\end{array}$ & $\begin{array}{c}4.4 \times 10^{-} \\
3 \mathrm{~g} / \mathrm{mL}\end{array}$ & $\begin{array}{c}5.5 \times 10^{-} \\
3 \mathrm{~g} / \mathrm{mL}\end{array}$ & $\begin{array}{c}6.6 \times 10^{-} \\
3 \mathrm{~g} / \mathrm{mL}\end{array}$ & $\begin{array}{c}7.7 \times 10^{-} \\
3 \mathrm{~g} / \mathrm{mL}\end{array}$ & $\begin{array}{c}\text { Control } \\
2\end{array}$ \\
\hline ClinoAu-500-2.5 & + & + & + & + & + & + & - & + \\
\hline FaujaAu-500-2.5 & + & + & + & + & + & - & - & + \\
\hline SilicAu-500-0.11 & + & + & + & + & + & - & - & + \\
\hline MordeAu-500-1.7 & + & + & + & + & + & - & - & + \\
\hline MordeAu-500-2.9 & + & + & + & + & + & - & - & + \\
\hline
\end{tabular}


5.2.4 Ensayo de CMI para materiales soporte-Au como biocida de S. typhi

La determinación de la CMI de los 4 aislados de S. typhi, expuestos a los materiales soporte-Au, se realizó a las condiciones y concentraciones del numeral 5.2.3. En el primer sondeo de $S$. typhi, después de incubación por 72 h, se observó que la bacteria creció en presencia de los discos impregnados de cualquier material soporte-Au; por lo que se planteó un segundo sondeo a concentraciones de $5.5 \mathrm{x}$ $10^{-3} \mathrm{~g} / \mathrm{mL}, 6.6 \times 10^{-3} \mathrm{~g} / \mathrm{mL}$, y $7.7 \times 10^{-3} \mathrm{~g} / \mathrm{mL}$.

La evaluación in vitro del segundo sondeo para el material ClinoAu-500-2.5, permitió observar que la cepa $S$. typhi presentó tolerancia a concentraciones inferiores a $7.7 \times 10^{-3} \mathrm{~g} / \mathrm{mL}$. Los materiales FaujaAu-500-2.5, MordeAu-500-1.7 y MordeAu-500-2.9, con una concentración de $5.5 \times 10^{-3} \mathrm{~g} / \mathrm{mL}$, fueron mortales para la bacteria. Para el caso de SilicAu-500-0.11, se requirió de una concentración de $6.6 \times 10^{-3} \mathrm{~g} / \mathrm{mL}$ para inhibir el metabolismo de la $S$. typhi, y por tanto su crecimiento.

El efecto sobre la inhibición del crecimiento de S. typhi debido a la presencia de los materiales soporte-Au se muestra en la Tabla 5.7.

Tabla 5.7. Concentraciones mínimas inhibitorias de los materiales soporte-Au para S. typhi.

\begin{tabular}{|c|c|c|c|c|c|c|c|c|}
\hline $\begin{array}{c}\text { Cepa/ Material } \\
\text { biocida }\end{array}$ & $\begin{array}{c}\text { Control } \\
1\end{array}$ & $\begin{array}{l}2.2 \times 10^{-3} \\
\mathrm{~g} / \mathrm{mL}\end{array}$ & $\begin{array}{l}3.3 \times 10^{-3} \\
\mathrm{~g} / \mathrm{mL}\end{array}$ & $\begin{array}{l}4.4 \times 10^{-3} \\
\mathrm{~g} / \mathrm{mL}^{-}\end{array}$ & $\begin{array}{l}5.5 \times 10^{-3} \\
\mathrm{~g} / \mathrm{mL}\end{array}$ & $\begin{array}{l}6.6 \times 10^{-3} \\
\mathrm{~g} / \mathrm{mL}\end{array}$ & $\begin{array}{l}7.7 \times 10^{-3} \\
\mathrm{~g} / \mathrm{mL}\end{array}$ & $\begin{array}{c}\text { Control } \\
2\end{array}$ \\
\hline ClinoAu-500-2.5 & + & + & + & + & + & + & - & + \\
\hline FaujaAu-500-2.5 & + & + & + & + & - & - & - & + \\
\hline SilicAu-500-0.11 & + & + & + & + & + & - & - & + \\
\hline MordeAu-500-1.7 & + & + & + & + & - & - & - & + \\
\hline MordeAu-500-2.9 & + & + & + & + & - & - & - & + \\
\hline
\end{tabular}

Las muestras expuestas a soporte-Ag y soporte-Au que no presentaron turbidez fueron sembradas en cajas petri con agar Müller-Hinton (Figura 5.23),observándose que el crecimiento de las bacteriasfue nulo. Esto demuestra que los materialestienen efecto bactericida tanto para E. coli como para S. typhi. Cabe señalar que se consideraron sistemas en donde no hubo crecimiento, aquellos tubos traslúcidos cuya turbidez era muy baja (menos de 50 NTU) o cercana a cero. Aquellos tubos con turbidez aparente y valores mayores a 50 NTU se consideraron sistemas con crecimiento microbiano. 
Con este método descriptivo de ensayo turbidimétrico se pueden obtener algunas respuestas sobre el comportamiento de las bacterias, en presencia de los agentes bactericidas, tales como supresión en el nivel de crecimiento en la fase estacionaria, disminución de la velocidad de crecimiento y la letalidad (Davidson and Parish, 1989).

Las CMls y CMBs obtenidaspor los dos métodos ensayados (macrodilución en líquido y microdilución en agar) no presentaron diferencias significativas. La eficacia, reflejo un radio $\mathrm{CMB} / \mathrm{CMI}$ menor a 1.2 , indicando que los materiales son bactericidas.

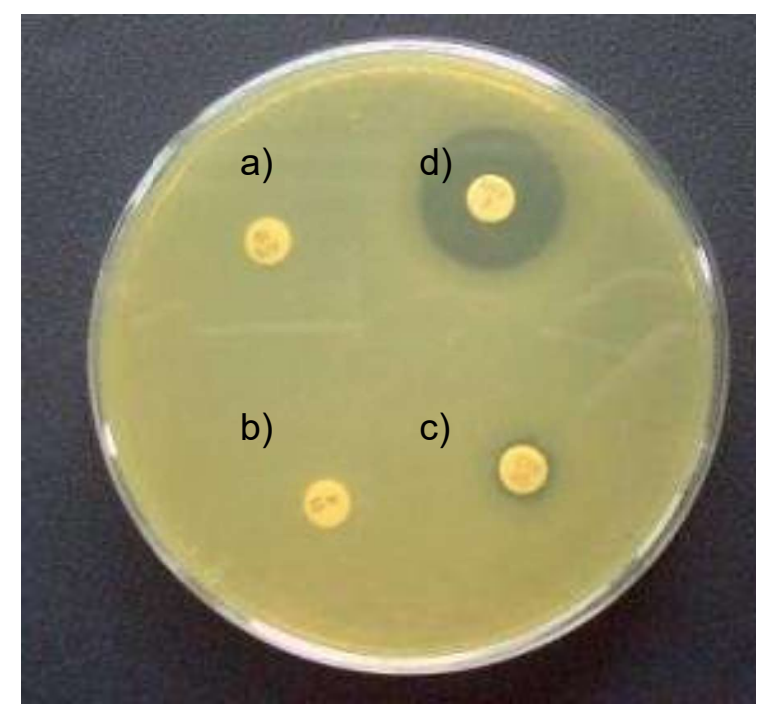

Figura 5.23. Antibiograma en medio sólido de S. typhi frente a FaujaAg-500-2.1, CMBs de: a) $2.2 \times 10^{-3}$, b) $3.3 \times 10^{-3}$, c) $4.4 \times 10^{-3}$ y d) $5.5 \times 10^{-3}$.

De las tablas 5.4 a 5.7 se puede concluir que la bacteria $S$. typhi fue más resistente a los materiales bactericidas soporte-Ag y soporte-Au que la bacteria $E$. coli. Esto probablemente se debe al grupo de genes plasmídicos responsable de la resistencia a la plata en $S$. typhi. La proteína periplásmica que entra en contacto con las partículas de $\mathrm{Ag}^{\delta+}$, específicamente en la superficie celular, representa la primera línea de resistencia contra la toxicidad de la plata. La membrana citoplasmática, al identificar a la plata como tóxica, la bombea desde la célula como lo hace con otros metales (por ejemplo $\mathrm{Cu}^{+}$y $\mathrm{Cd}^{2+}$ ). Esta bomba consiste en tres proteínas, una en la membrana interna, otra en la membrana externa y una 
tercera formando un puente en el espacio periplásmatico (Figura 5.24). Al incrementar la CMI ocurre un potencial de la membrana, los sensores de potencial de la membrane, los sensors de potencial comienzan a moverse en el campo eléctrico de la membrana citoplasmática (parcialmente negative), abriendo los canals de absorción y una vez abierto el canal comienza el proceso de inactivación, el cual consiste en la oclusión del poro en la cara intracelular producido por la partícula de inactivación $\left(\mathrm{Ag}^{\delta+} \circ \mathrm{Au}^{\delta+}\right)$ destruyendo parte de la membrana. Este proceso permite la disponibilidad para la conducción iónica de la membrana y las proteínas no pueden expulsar por completo a la $\mathrm{Ag}^{\delta+}$ y $\mathrm{Au}^{\delta+}$ por lo que la membrana se destruye.

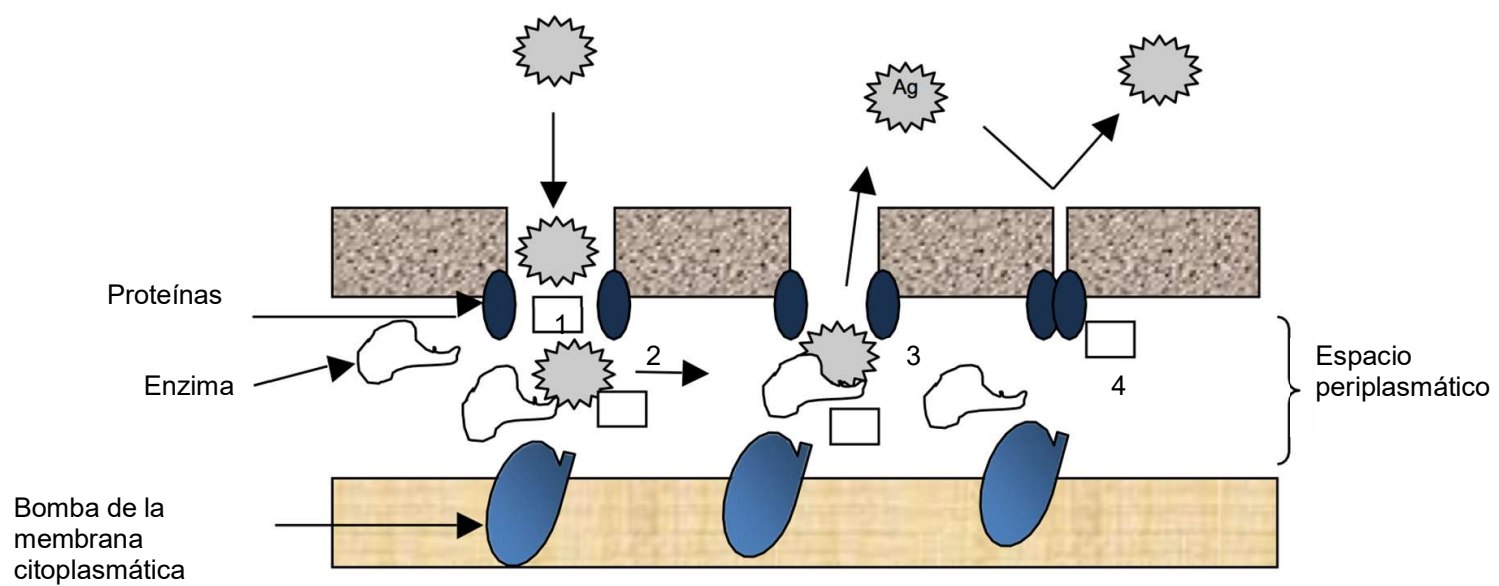

Figura 5.24. Mecanismo de resistencia de las bacterias a la plata: 1) identificación de un material tóxico, 2) ligando de las proteínas y enzimas con el elemento tóxico, 3) Bombeo a la parte externa de la célula y 4) Cierre de porinas.

\subsection{Materiales como inhibidores del crecimiento bacteriano}

Debido a que la técnica turbidimétrica depende del tamaño de las células bacterianas, así como de la presencia de células dañadas (Skandamis P. et al., 2001), se realizaron pruebas microbiológicas para obtener curvas de crecimiento de los microorganismos en estudio (E. coli y S. typhi) en presencia de los materiales soporte-Ag y soporte-Au como agentes antimicrobianos, debido a que algunos materiales tienden a quedar suspendidos en soluciones acuosas y por tanto afectan las mediciones de turbidez. En la figura5.25 se observa el efecto 


\section{Capítulo 5}

inhibitorio en placa microbiana de las bacterias en estudio expuestas a los soportes y a los soportes-Ag, respectivamente.

a)

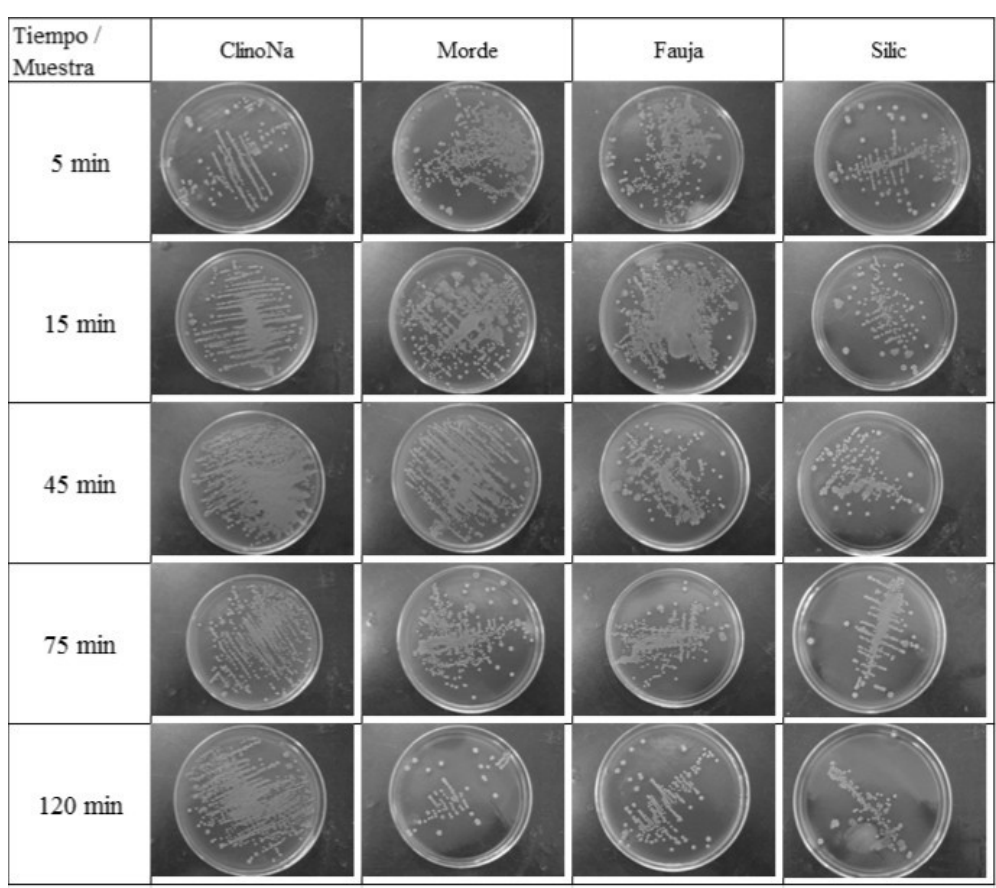

b)

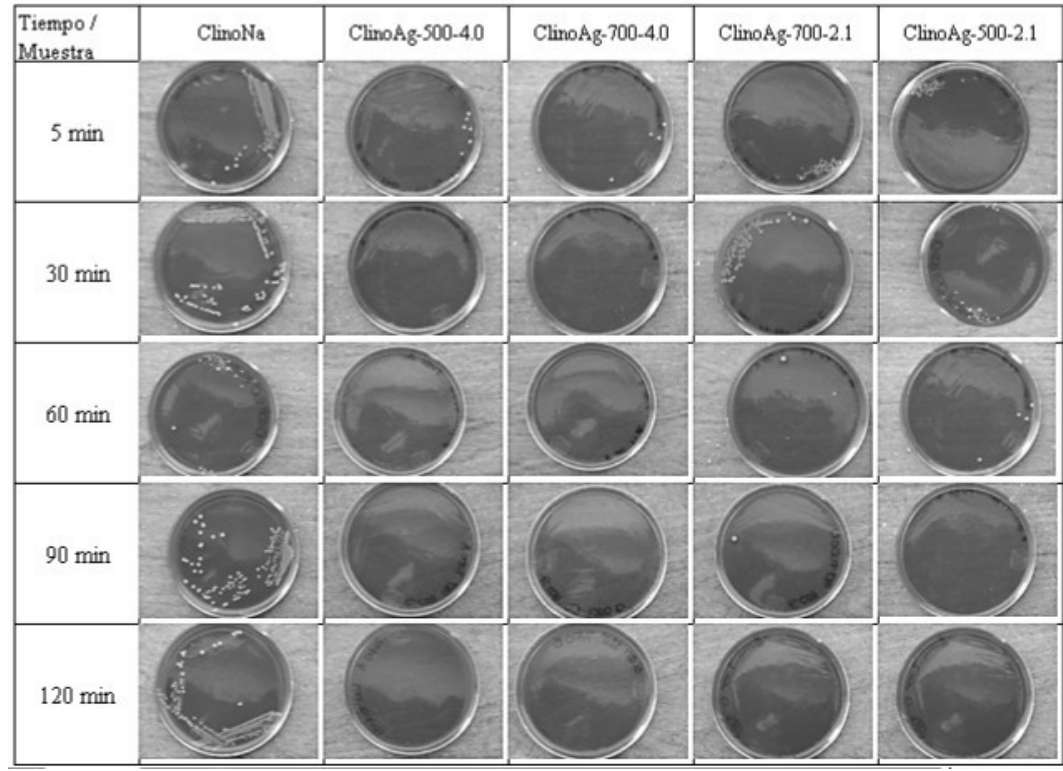

Figura 5.25. Crecimiento de colonias de E. coli expuestas a $7.7 \times 10^{-3} \mathrm{~g} / \mathrm{mL}$ del material a) soportes sin plata b) soportes con plata (ClinoAg-X-Y). 
Antes de evaluar el carácter bactericida de los materiales se realizaron los controles de calidad a las cepas de trabajo por microdiluciones. Los resultados de los controles de calidad (viabilidad y pureza) de E. coli y S. typhi, empleados en la evaluación bactericida, cumplieron con los criterios de aceptación al obtenerse valores de viabilidad del orden de $1 \times 10^{8}$, de modo que los resultados de pureza para ambos microorganismos cumplen con la condición de cultivos libres de contaminación microbiana.

El crecimiento microbiano y el conteo de colonias de las cepas de E. coli y S. typhi, en presencia de los diferentes materiales conteniendo plata u oro, se calcularon teniendo en cuenta el número de colonias crecidas en la suspensión de microorganismos inoculados (No) y las colonias crecidas $(\mathrm{N})$, Ecuación 5.1.

$$
\log (\mathrm{No})-\log (\mathrm{N})=\text { Reducción logarítmica }
$$

\subsubsection{Soporte-Ag como biocidas de E. coli}

La figura 5.26 presenta el efecto biocida de las muestras de ClinoAg-X-Y sobre E. coli. Como una muestra de referencia, la zeolita sin plata también se evaluó. En este último caso, el número de colonias aumentó rápidamente con el tiempo, mostrando que el soporte no es bactericida. En cambio,con una carga de $4 \%$ en peso de $\mathrm{Ag}$ a una $\mathrm{CMI}$ de $3.3 \times 10^{-3} \mathrm{~g} / \mathrm{mL}$, independientemente de la temperatura de reducción, se eliminó a la $E$. coli a un tiempo de $30 \mathrm{~min}$. Por el contrario, las muestras con menor cantidad de plata permiten la reproducción de las bacteriasdurante los primeros $30 \mathrm{~min}$. A partir de los 60 min hubo una disminución en el número de colonias, pero fue hasta los 120 min cuando las colonias fueron eliminadas por completo. Por tanto, parece que la distribución de la plata en la superficie del material es un parámetro crucial para obtener materiales eficientes como inhibidores del crecimiento bacteriano. Por un lado, en un material con un alto contenido de $\mathrm{Ag}$, las bacterias están en contacto rápidamente con las partículas de plata grandes y densas, dispersas en la superficie externa de la zeolita. Por otro lado, con un contenido de $\mathrm{Ag}$ de $2.1 \%$ en peso en las zeolitas, las bacterias se dispersan en la zeolita mejorando su 
desarrollo, pero con el tiempo las bacterias se ponen en contacto con los sitios de plata situada en la entrada de los canalesde la zeolita y algunos otros en la superficie externa.

La relación masa de Ag-zeolita/volumen de medios de cultivo, para el caso de la zeolita cargada con un $4 \%$ en peso de plata, parece ser muy eficiente y las bacterias sobrevivieron sólo por muy poco tiempo. Cuanto menor es la cantidad de Clino-Ag más largo es el tiempo para alcanzar el menor número de colonias sobrevivientes. Como se mostró por MET, la mayoría de las partículas de plata tienen tamaño menor a10nm de diámetro, parece así, que estas partículas no son inmediatamente accesibles a las bacterias, posiblemente porque estas partículas se estabilizan en la entrada de los canales. Aunque estas partículas no son en un primer momento accesibles, las bacterias utilizan la superficie externa para reproducirse, aumentando el número de colonias, pero son rápidamente eliminadas cuando las partículas de plata son accesibles.

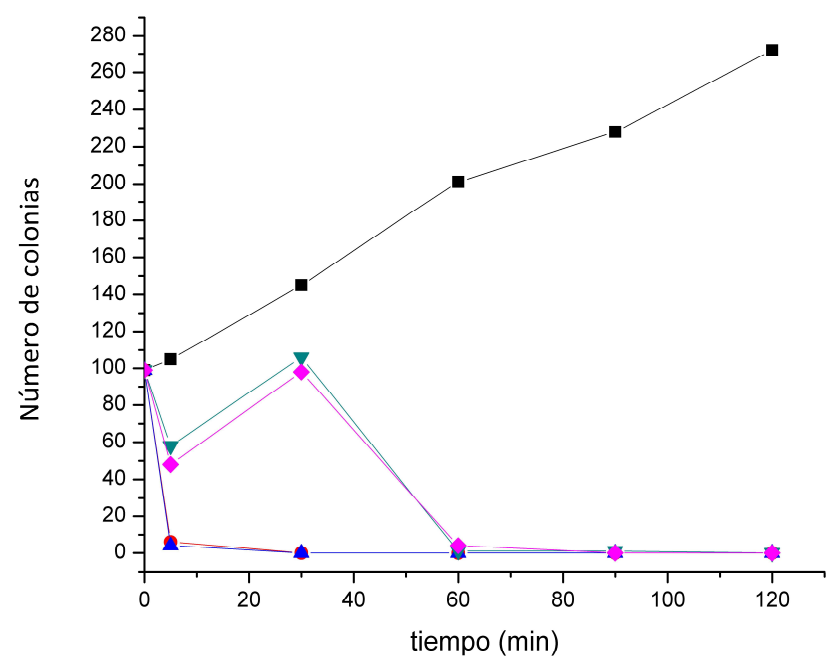

Figura 5.26. Efecto inhibitoriode ClinoAg-X-Ya CMIs de $3.3 \times 10^{-3} \mathrm{~g} / \mathrm{mL}$ sobre el crecimiento de E. coli:

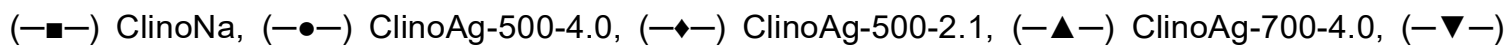
ClinoAg-700-2.1.

La E. coli en contacto con los materiales ClinoAg-X-2.1 presentó una fase larga (aproximadamente $60 \mathrm{~min}$ ) de inactivación bactericida, lo cual se atribuye a 
que las partículas de tamaño menor a $7.5 \mathrm{~nm}$ no son accesibles inmediatamente, propiciando que el soporte favorezca la reproducción de las bacterias, pero después de este intervalo estas partículas entran en contacto con la bacteria, superando los mecanismos de defensa celular. El ataque a los componentes de la pared celular provoca su ruptura y por consecuencia la pérdida de sus funciones.

Posteriormente, la descomposición de la pared celular permite el contacto de las especies $\mathrm{Ag}^{\delta+}$ con la membrana celular y la oxidación alos fosfolípidos provocando los desórdenes funcionales que conducen a la muerte celular (Srinivasan C., 2003).

En la figura 5.27 se grafica el número de colonias de E. coli en función del tiempo, en presencia de los materiales Fauja y FaujaAg-500-2.1. Los resultados de las evaluaciones de crecimiento bacteriano indican que la $E$. coli fue capaz de tolerar la presencia del material Fauja. Por otra parte, el material FaujaAg-500-2.1 inhibió por completo el crecimiento de E. coli. De acuerdo con la figura 5.27, a los 5 min de exposición, a una CMI de $3.3 \times 10^{-3} \mathrm{~g} / \mathrm{mL}$ se presentó toxicidad, eliminando el $95 \%$ del número de colonias iníciales y el 100\% después de 30 min. Este resultado evidencia que las partículas de plata en el soporte son accesibles para las bacterias.

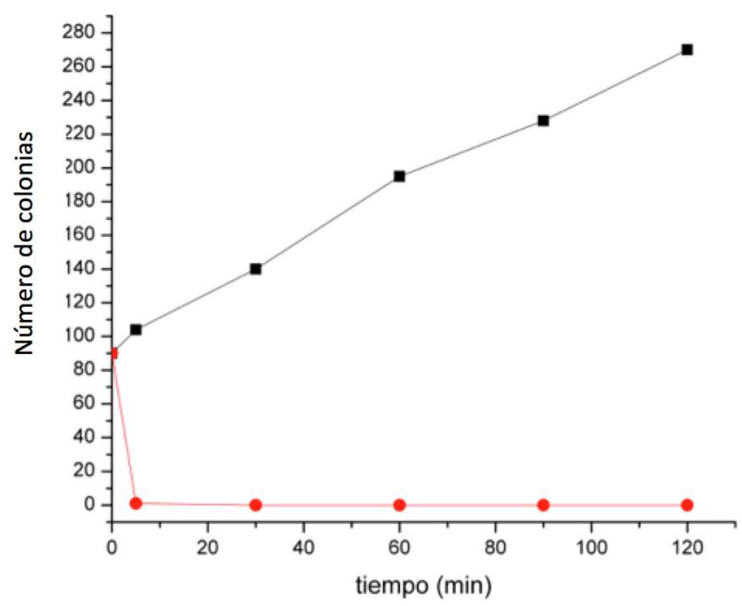

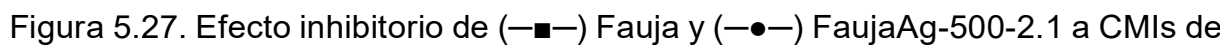


En las pruebas con material SilicAg-500-0.11, a unaCMI de $4.4 \times 10^{-3} \mathrm{~g} / \mathrm{mL}$, se observa unefecto bactericidasobre E. coli. El efectoes notable desde el primer momento en que se pone en contacto a la bacteria con el material biocida. Esta inhibición inmediata se debe altamaño de partículas que predominan en el material (10-15 nm) las cuales son accesibles a la bacteria. El área específica del soporte también tiene un papel importante en la acción bactericida. Esto lo confirmala acción bactericida de los materiales con mayor área específica, casos de SilicAg- 500-0.11 y FaujaAg-500-2.1, que eliminaron más rápidamente las bacterias, lo que también es una consecuencia de la alta dispersión de las partículas en la alta área superficial de estos materiales. En relación a los resultados previamente comentados, el material SilicAg-500-0.11 con una CMI mayor al material FaujaAg-500-2.1 elimina totalmente las colonias después de $30 \mathrm{~min}$. Sin embargo, el contenido de plata del material SilicAg-500-0.11 representa apenas el 5.24\% respecto al contenido de plata en el material FaujaAg-500-2.1. La figura 5.28 presentala curva del número de colonias que sobrevivieron al paso del tiempo en los medios de cultivo y en presencia de la muestra de SilicAg-500-0.11.

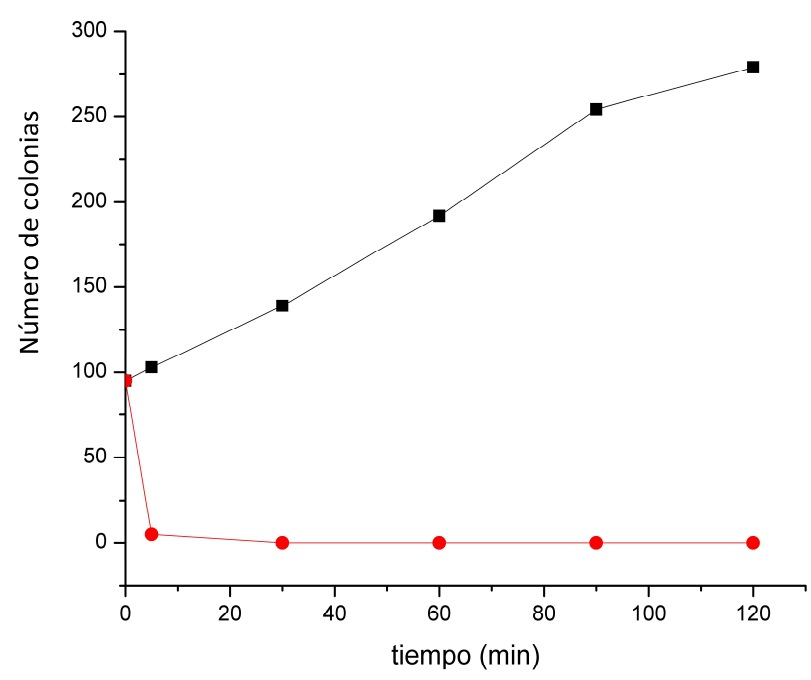

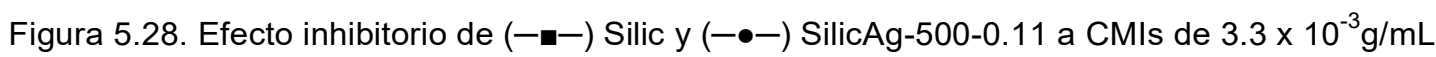
sobre el crecimiento de E. coli. 
Hasta ahora se ha demostrado que la plata soportada en diferentes zeolitas tiene propiedades bactericidas para E. coli. Otros autores (Shahverdi A., 2007; Lara H., 2010), ya habían reportado a la plata iónica como elemento bactericida. No obstante, la plata iónica reacciona con los elementos del medio disminuyendo así su probabilidad de contacto con la bacteria, por lo que se requiere de una alta concentración de plata iónica. Así, los resultados que se acaban de exponer prueban que la plata parcialmente cargada, soportada en diferentes zeolitas, es igualmente eficiente como bactericida y se requiere una menor cantidad para inhibir el crecimiento bacteriano, además de que el material soporte-Ag puede reutilizarse.

\subsubsection{Soporte-Ag como biocidas de S. typhi}

Para evidenciar la actividad bactericida de la Ag soportada contra la S. typhi, se expuso la bacteria a los materiales con y sin Ag. La figura 5.29 presenta los resultados obtenidos con los materiales ClinoNa y ClinoAg-X-Y. Se observó crecimiento de $S$. typhien presencia de ClinoNa, igual que se observó también para E. coli. La velocidad de reproducción sobre este soporte fue más rápida para E. coli que para S. typhi. Esto puede explicarse como un estrés de la S. typhi debido a que el experimento se inició con 200 colonias mientras que en el experimento con E. coli se partió de 100 colonias. Se observó inhibición del crecimiento de la S. typhi con los materiales ClinoAg-X-Y con una CMI de $6.6 \times 10^{-3} \mathrm{~g} / \mathrm{mL}$. Los materiales ClinoAg-X-2.1 fueron efectivos como bactericidas contra S. typhi después de los 90 min. El crecimiento de la $S$. typhi en presencia de ClinoAg-X-4.0 fue similar a lo observado con la E. Coli. El crecimiento de la S. typhi se inhibió por completo en 30 mincon los materiales Clino-X-4.0, debido a que estos materiales contienenpartículas que pueden considerarse de tamaño mediano (10 nm). 


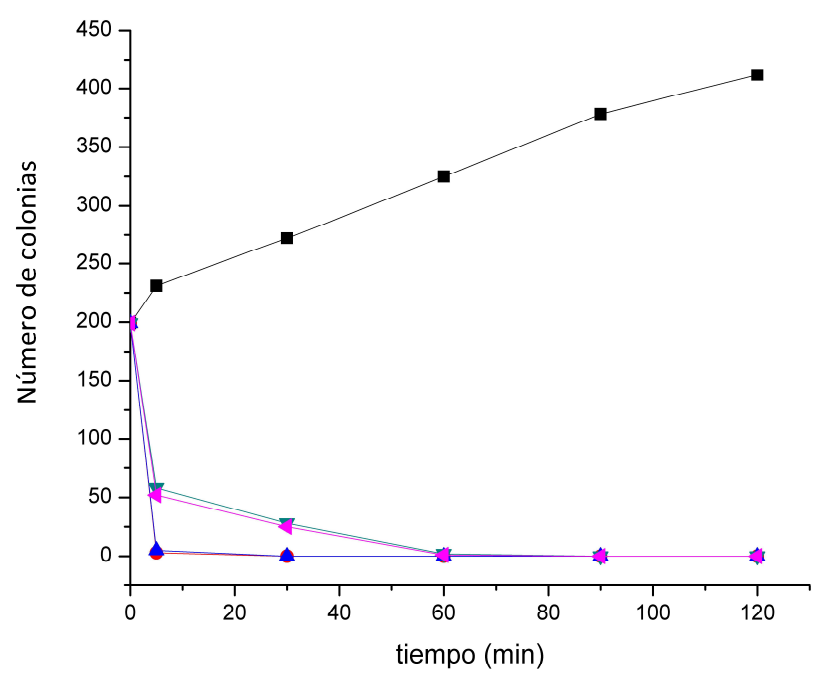

Figura 5.29. Efecto inhibitoriode ClinoAg-X-Ya CMls de $6.6 \times 10^{-3} \mathrm{~g} / \mathrm{mL}$ sobre el crecimiento de $S$.

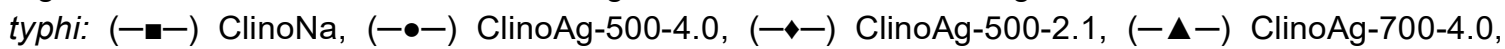
$(-\nabla-)$ ClinoAg-700-2.1.

A diferencia de lo observado en la exposición de E. coli a los materiales ClinoAg-X-2.1, la S. typhi no presentó una fase larga de inactivación bacteriana, lo cual se atribuye al tamaño de población bacteriana en el medio; una mayor cantidad de colonias propicia un estrés en la bacteria por lo que los mecanismos de defensa bacterianos son superados rápidamente por las partículas de $\mathrm{Ag}^{\delta+}$.

En la figura 5.30 se aprecia que el material Fauja no inhibió el crecimiento de la S. typhi. En cambio, el crecimiento de S. typhi en presencia de FaujaAg-500- 2.1, con una CMI de $4.4 \times 10^{-3} \mathrm{~g} / \mathrm{mL}$, se redujo hasta en un $75 \%$ en los primeros $5 \mathrm{~min}, \mathrm{y}$ a los 30 min ya se había inhibido un $85 \%$. Al cabo de 120 min de exposición de eliminó el $100 \%$ de las colonias. 


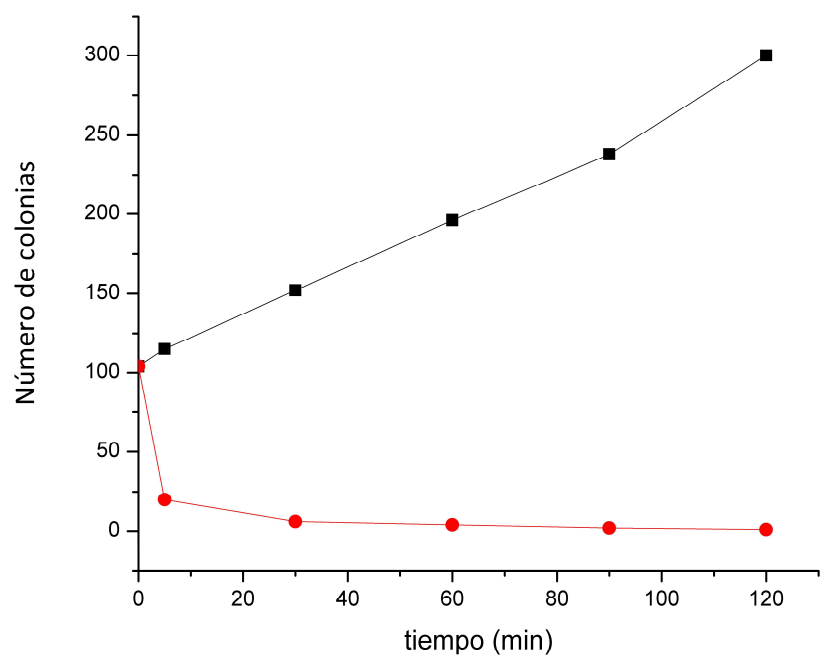

Figura 5.30. Efecto inhibitorio de (-๑) Fauja y (-๑-) FaujaAg-500-2.1 a CMls de $\times 10^{-3} \mathrm{~g} / \mathrm{mL}$ sobre el crecimiento de $S$. typhi.

Las curvas de crecimiento de la S. typhi en presencia de Silic y SilicAg- 5000.11 se muestran en la figura 5.31. Nuevamente, se observa que la curva correspondiente a las bacterias que interactúan con el material sin plata (Silic) no tiene efecto bactericida para $S$. typhi. La curva obtenida del crecimiento de la $S$. typhi, expuesta a SilicAg-500-0.11a una CMI de $5.5 \times 10^{-3} \mathrm{~g} / \mathrm{mL}$, está muy por debajo de la correspondiente al control, mostrando que este material inhibe el crecimiento en un $65 \%$ en los primeros $5 \mathrm{~min}, 92 \%$ a los $60 \mathrm{~min}$ y el $100 \%$ a los 120 min. El material SilicAg-500-0.11 mostró en todo momento un efecto bactericida. 


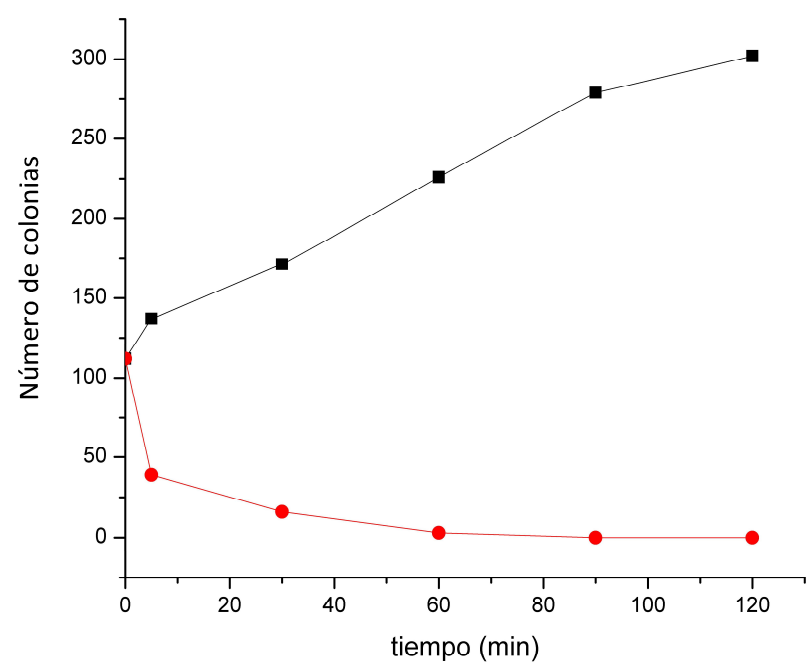

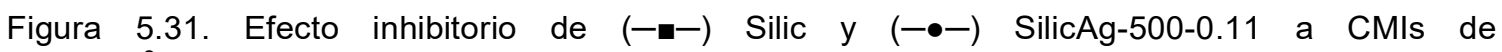
$5.5 \times 10^{-3} \mathrm{~g} / \mathrm{mL}$ sobre el crecimiento de S. typhi.

Para determinar las curvas de crecimiento bacteriano se realizaron un total de tres experimentos por material. Los resultados de las curvas corresponden a la media de los tres experimentos. Sólo se incluyen los experimentos en los que la viabilidad inicial fue superior al $85 \%$. La pauta de administración de los materiales bactericidas está en función a la CMI determinada.

Los resultados indican que la exposición de la S. typhi, frente a los materiales soporte-Ag durante un periodo de $5 \mathrm{~min}$, reduce significativamente el número de bacterias. Estos resultados sugieren que se puede eliminar totalmente las bacterias presentes al prolongar el tiempo de exposición o al incrementar la CMI.

Los soportes sin plata permitieron el desarrollo de las bacterias de E. coli y S. typhi. De entre todos los soportes evaluados, la Silic presentó mayor crecimiento de bacterias en el periodo de los $120 \mathrm{~min}$ de exposición. Este resultado por supuesto debe atribuirse a la mayor área superficial de la silicalita. De los resultados de inhibición del crecimiento bacteriano con los materiales soporte-Ag, se observó que en los materiales FuajaAg-500-2.1 y SilicAg-500-0.11 con mayor área específica $166 \mathrm{~m}^{2} / \mathrm{g}$ y $397 \mathrm{~m}^{2} / \mathrm{g}$, respectivamente, eliminan más rápidamente a las bacterias. Comparando el tamaño de partícula en estos dos 
materiales, en el SilicAg-500-0.11, donde predomina el tamaño de 10-12.5 nm, la eliminación de las colonias bacterianasfuemás rápida.

\subsubsection{Soporte-Au como biocidas de E. coli}

Con el fin de comprobar que la CMI de los materiales soporte-Au encontrada para la $E$. coli es adecuada, se realizó un análisis de CMI en función del tiempo de exposición, efectuando los correspondientes conteos de colonias bacterianas formadas. Los conteos se realizaron por $120 \mathrm{~min}$ con CMls de $7.7 \times 10^{-3} \mathrm{~g} / \mathrm{mL}$.

En la figura 5.32 se observa que el material ClinoNa no tiene efecto bactericida para E. coli. La ClinoAu-500-2.5 presentó propiedades bactericidas en los 120 min de exposición. En los primeros 60 min, este material eliminó el 43\% de las colonias de E. coli. A tiempos más largos se encontró que ya no hubo una eliminación bacteriana significativa, hubo un comportamiento bacteriostático. Sin embargo, en los cultivos de las muestras a los 120 min, se observó que el diámetro de las colonias esmenor a aquel observado en los controles. Además se observó un cambio en la morfología de las colonias, de circular a arborescente, que puede ser un indicativo de que se encuentra sujeta a un estrés por la presencia del Au. 


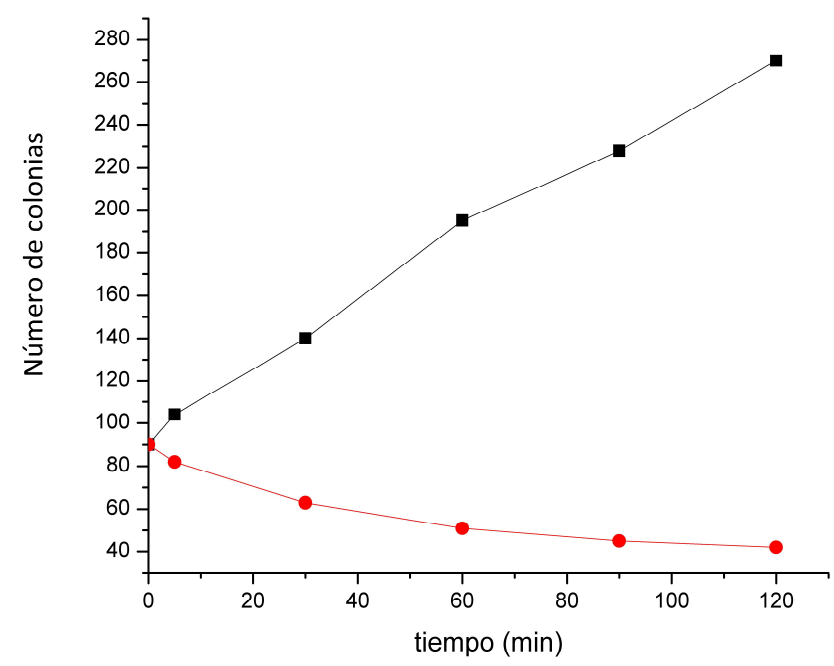

Figura 5.32. Efecto inhibitorio de (- - C) ClinoNa y (-•-) ClinoAu-500-2.5 a CMIs de 6.6 $\times 10^{-3} \mathrm{~g} / \mathrm{mL}$ sobre el crecimiento de E. coli.

En la figura 5.33 se grafica el número de colonias de $E$. colique sobrevivieron en función del tiempo en presencia de los materiales Morde, MordeAu-500-1.7 y MordeAu-500-2.9. El material Morde no presentó ningún efecto bactericida sobre el crecimiento de E. coli. Por el contrario, los materiales MordeAu-500-1.7 y MordeAu-500-2.9 tienen propiedades bactericidas, con una inhibición significativa de $56 \%$ y $62 \%$, respectivamente, a los 5 min de exposición. A diferencia del material MordeAu-500-2.9, el material MordeAu-500-1.7 presentó un comportamiento bacteriostático en el intervalo de 5 a 60 min, seguido de una moderada inhibición bactericida. El material MordeAu-500-2.9 presentó una inhibición bacteriana moderada en el intervalo de 5 a 90 min debido a que las bacterias no entran en contacto con todas las partículas porque los sedimentos de algunas bacterias muertas formaron una película en la superficie del material. Este resultado fue exclusivo de este material y la caracterización llevada a cabo no permite concluir sobre este comportamiento.

El mayor poder bactericida de MordeAu-500-2.9 puede atribuirse al tamaño de las partículas de oro, en su mayoría de $20 \mathrm{~nm}$. Parece ser las bacterias tienen 
acceso directo a estas partículas, reduciendoel número de las colonias bacterianas en los primeros $5 \mathrm{~min}$.

La concentración de Au en ambos materiales no fue suficiente para inhibir totalmente al microorganismo en un tiempo de $120 \mathrm{~min}$, sin embargo, ambos materiales inocularon más del 70\% del inóculo inicial. El material MordeAu-500-2.9 demostró un mayor poder bactericida, alcanzando una inhibición del 82\% de las colonias iníciales, en contraste con el material MordeAu-500-1.7, el cual logró una inhibición del $72 \%$ de los colonias del inoculo inicial. El mayor poder bactericida de MordeAu-500-2.9 puede atribuirse a la mayor concentración de Au en el material y al tamaño de las partículas de Au.

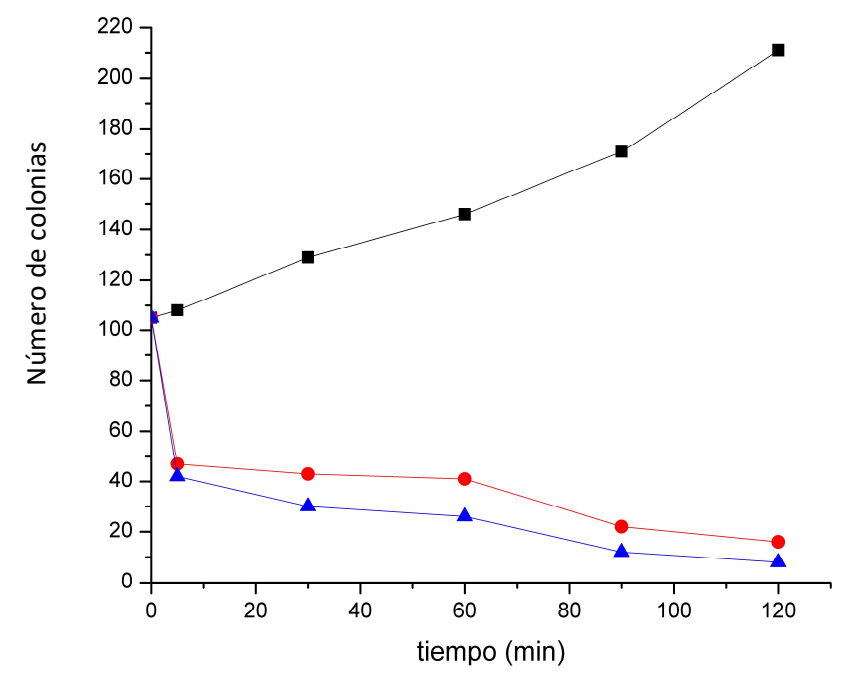

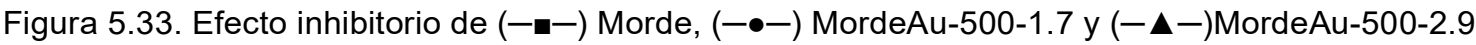
a CMIs de $6.6 \times 10^{-3} \mathrm{~g} / \mathrm{mLsobre}$ el crecimiento de E. coli.

En la figura 5.34 se presentan las curvas del número de colonias de $E$. coli en función del tiempo en presencia de los materiales Fauja y FaujaAu-500-2.5. Los resultados de las evaluaciones de crecimiento bacteriano indican que la $E$. coli fue capaz de tolerar la presencia del material Fauja, por otra parte el material FaujaAu500-2.5 inhibió por completo el crecimiento E. coli en un corto tiempo. De acuerdo con la figura 5.34, el material FaujaAu-500-2.5, a una CMI de $6.6 \times 10^{-}$ 
${ }^{3} \mathrm{~g} / \mathrm{mL}$ presentó toxicidad,y eliminó el $55 \%$ del número de colonias iníciales y el $92 \%$ después de 5 y120min, respectivamente.

Al compararel poder inhibitorio del crecimiento bacteriano de los materiales FaujaAu-500-2.5 y MordeAu-500-1.7, se observó que ambos tienen una inhibición porcentual similar a los 5 min, sin embargo, el material FaujaAu-500-2.5 presentó mayor inhibición después de este tiempo, esto sugiere que la mayor área específica del material FaujaAu-500-2.5 permite a la bacteria estar más fácilmente en contacto con el material y así se elimina más rápido.

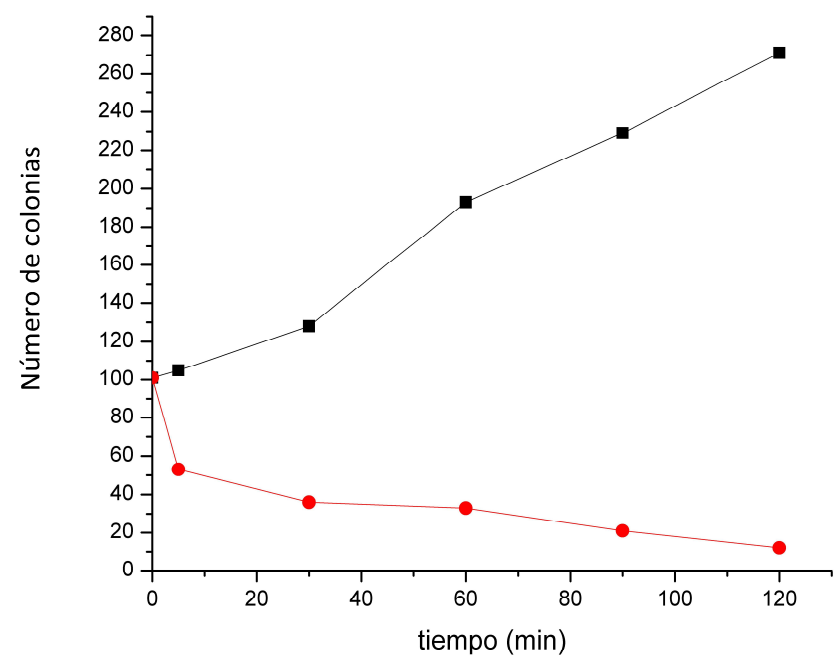

Figura 5.34. Efecto inhibitorio de(-匹-) Fauja y (-•-) FaujaAu-500-2.5 a CMls de 6.6 x $10^{-3} \mathrm{~g} / \mathrm{mL}$ sobre el crecimiento de $E$. coli.

En los resultados del monitoreo bacteriológico de la $E$. coli expuesta a los materiales Silic y SilicAu-500-0.11, se observó que el material Silic no tuvo comportamiento bactericida. El material SilicAu-500-0.11 presenta un comportamiento similar al observado en las pruebas de exposición de la $E$. coli a los materiales MordeAu-500-Y y FaujaAu-500-2.5. En los primeros 5 min de exposición, el material SilicAu-500-0.11 inhibe el 53\% de las colonias iníciales. Para tiempos de exposición más largos se aprecia una inhibición bactericida moderada hasta los 60 min inhibiendo el $89 \%$ de las colonias de $E$. coli; sin embargo después de este tiempo el poder de inhibición bactericida es lento. La 
CMI de SilicAu-500-0.11 no fue suficiente para inhibir totalmente al microorganismo en un tiempo de 120 min, inhibió al 96\% de E. coli.

La inhibición del crecimiento microbiano alcanzada con SilicAu-500-0.11 en función del tiempo está reflejada en la figura 5.35.

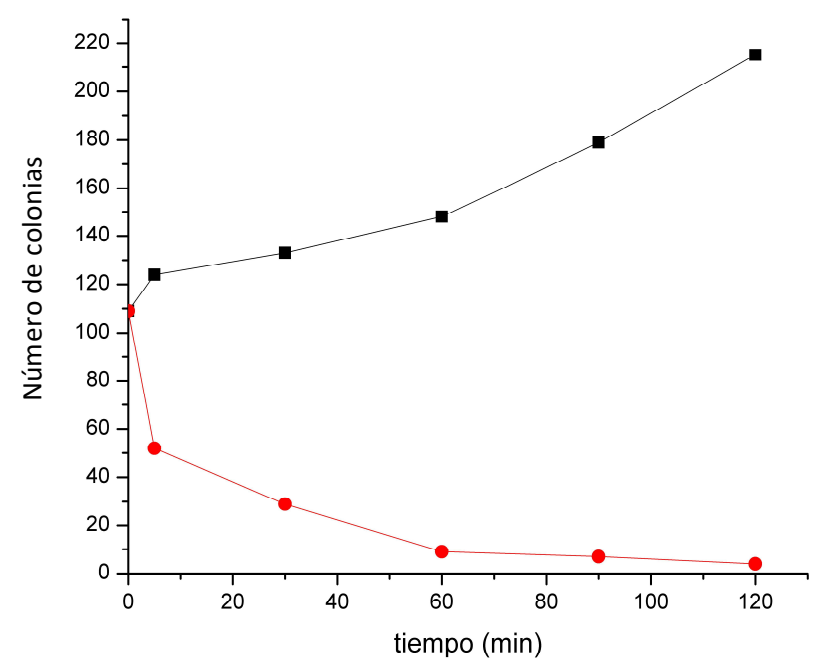

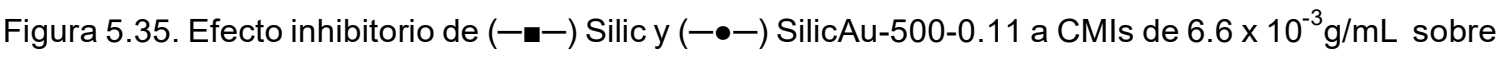
el crecimiento de E. coli.

Es importante señalar que, en todas las evaluaciones del sistema como bactericidas de E. coli, las colonias adquieren una coloración rosa, lo cual indica que el Au se incorporó a la bacteria, aunque haría falta un estudio que profundice en los mecanismos a través de los cuales tiene lugar este fenómeno. Además este resultado sugiere que el oro se libera del material, lo cual no es del todo satisfactorio para un buen material bactericida. Aún así el material podría utilizarse varias veces y después recargarse de oro.

Todos los materiales soporte-Au con CMls de $6.6 \times 10^{-3} \mathrm{~g} / \mathrm{mL}$ presentaron características bactericidas frente a la E. coli. Las CMls de los materiales no fue suficiente para eliminar el total de las colonias en un tiempo de $120 \mathrm{~min}$, sin embargo se aprecia una inhibición mayor al $70 \%$ del inoculo inicial frente a los materiales SilicAu-500-0.11, MordeAu-500-1.7, MordeAu-500-2.9 y FaujaAu-500-

2.1. De acuerdo a las recomendaciones descritas por la Agencia de Protección 
Ambiental de las Naciones Unidas, una reducción de al menos el $33 \%$ de la población bacteriana, es suficiente para considerarse buen desinfectante (EPA, 1978). La mayoría de los materiales soporte-Au (a excepción de la ClinoAu-5002.5) frente a $E$. coli, mostraron una alta inhibición bactericida en los primeros 5 min de exposición, una moderada inhibición bactericida en los siguientes 55 min y un bajo poder bactericida después de los $60 \mathrm{~min}$. Al comparar la concentración de Au en los soportes y tiempo de contacto con la bacteria, el SilicAu-500-0.11 fue el mejor inhibidor de la E. coli, eliminando el $96 \%$ de las bacterias. La ClinoAu-500-

2.5 presentó la menor inhibición para la $E$. coli con tan solo el $46 \%$ de bacterias eliminadas en el mismo tiempo. Lo anterior puede atribuirse al área específica de los materiales soporte-Au. Los materiales con mayor área específica eliminaron la mayor cantidad de bacterias a tiempos más cortos. Por ejemplo, el material SilicAu500-0.11 presenta mayor área específica (418 $\left.\mathrm{m}^{2} / \mathrm{g}\right)$ y el ClinoAu-500-2.5 la menor $\left(88 \mathrm{~m}^{2} / \mathrm{g}\right)$. Otro factor que influye en la inhibición bacteriana es el tamaño de partícula, los materiales con partículas de $5 \mathrm{~nm}$ eliminaron mayor porcentaje de bacterias a tiempos más cortos, como es el caso de FaujaAu-500-2.5 y SilicAu- 5000.11 .

\subsubsection{Soporte-Au como biocidas de S. typhi}

La figura 5.36 muestra las curvas de crecimiento correspondientes a la $S$. typhi en presencia de materiales ClinoNa y ClinoAu-500-2.5. Se observó un crecimiento de $S$. typhi en presencia de ClinoNa, en tanto que la ClinoAu-500-2.5 inhibió el 38\% de la bacteria en 5 min de exposición. El bactericida ClinoAu-50025 eliminó el $53 \%$ y el $65 \%$ del total de las colonias a 90 y $120 \mathrm{~min}$, respectivamente. Este resultado muestra que la $\mathrm{CMI}$ requiere de tiempos más largos para la eliminación total de la bacteria. Es importante mencionar los cambios morfológicos de las colonias que sobreviven a los $120 \mathrm{~min}$. Al igual que en el caso de E. coli la forma de las colonias cambio de circular a arborescente, lo cual sugiere un estrés; el diámetro de las colonias fue menor a las observadas en los controles. Esto puede deberse a que el Au influye en la estabilidad de enzimas 
ligninolíticas en el medio extracelular, como la formación de peróxidos, ya que en presencia del metal pesado puede ocurrir estrés oxidativo.

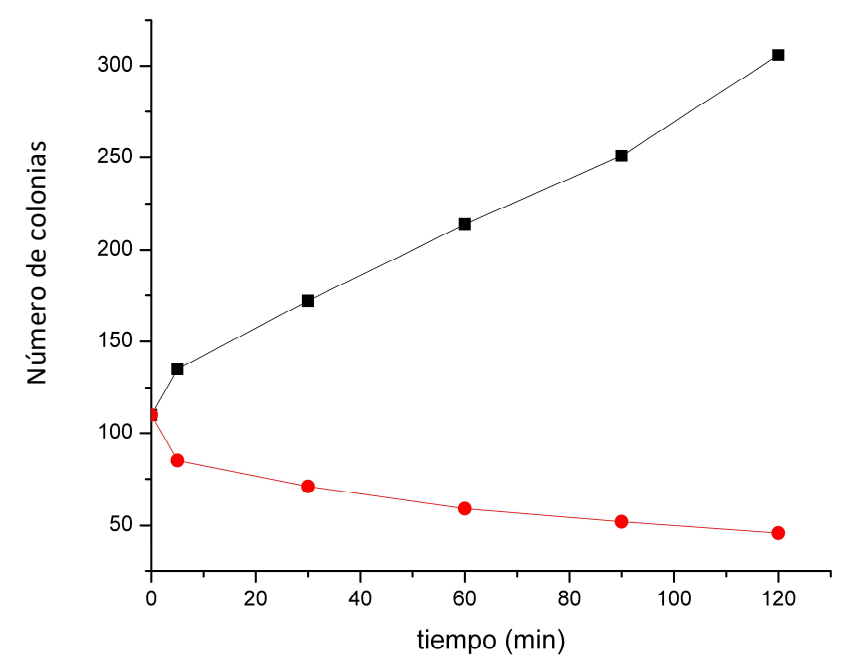

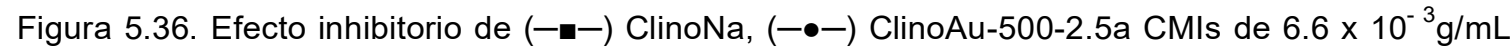
sobre el crecimiento de S. typhi.

En la figura 5.37se grafica el número de colonias de S. typhi que sobrevivieron frente a los materiales Morde, MordeAu-500-1.7 y MordeAu-5002.9. El material Morde, como se esperaba, no tuvo efecto bactericida. La MordeAu500-1.7 y la MordeAu-500-2.9 presentaron similitud en la inhibición a los 5 min, eliminando a la bacteria en $52 \%$ y $61 \%$ respectivamente, demostrando que con una CMI de $6.6 \times 10^{-3} \mathrm{~g} / \mathrm{mL}$ ambos materiales son bactericidas para S. typhi. A diferencia del material MordeAu-500-2.9, el material MordeAu-500-1.7 presentó un comportamiento bacteriostático de los 5 hasta los $60 \mathrm{~min}$, seguida de una moderada inhibición bactericida. El material MordeAu-500-2.9 presentó una inhibición bacteriana moderada entre los 5 y los 90 min, continuando con un bajo poder bactericida. La MordeAu-500-2.9, con mayor concentración de oro, eliminó más rápido a la S. typhi. La concentración de Au en ambos materiales no fue suficiente para inhibir por completo el crecimiento de colonias bacterianas en los $120 \mathrm{~min}$ del ensayo, sin embargo, ambos materiales eliminaron más del $80 \%$ de las colonias del patógeno. La actividad bactericida de los materiales MordeAu- 
500-1.7 y la MordeAu-500-2.9 para la $S$. typhi fue muy similar en el periodo de evaluación, en ambos casos el número de colonias disminuyó muy rápido en los primeros 5 min y después, en un periodo de 60 min solo disminuye el $8 \%$.

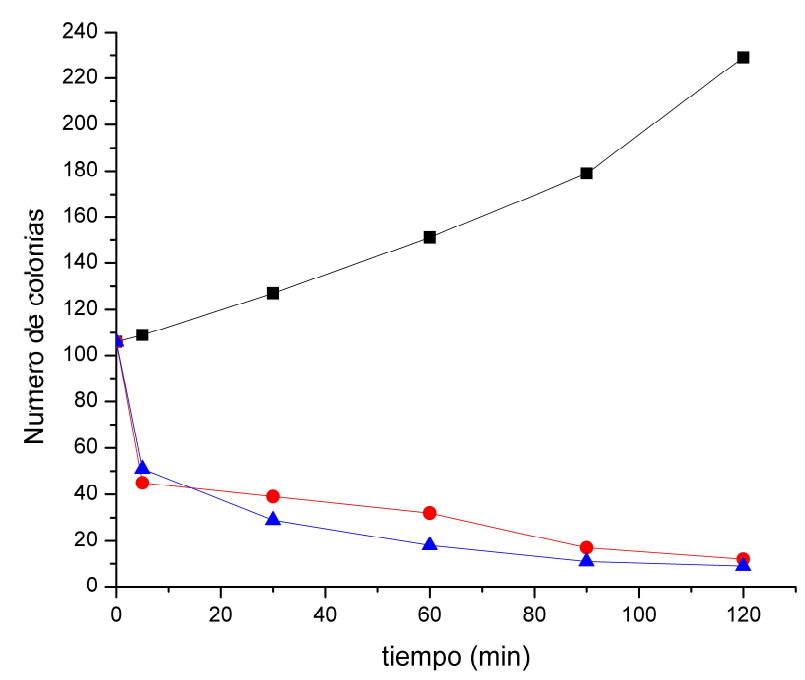

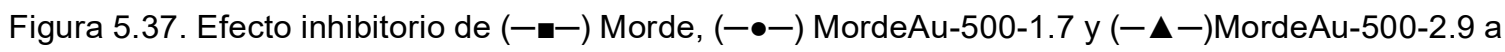
CMls de $6.6 \times 10^{-3} \mathrm{~g} / \mathrm{mL}$ sobre el crecimiento de $S$. typhi.

En la figura 5.38 se aprecia que, el material Fauja no inhibió el crecimiento de la S. typhi. La curva control demostró que sin la presencia de Au en el soporte no existe inhibición bacteriana.

El crecimiento de S. typhi en presencia de FaujaAu-500-2.5, con una CMI de $4.4 \times 10^{-3} \mathrm{~g} / \mathrm{mLse}$ redujo hasta en un $65 \%$ en los primeros $5 \mathrm{~min}$, y a los $30 \mathrm{~min}$ ya se había inhibido un 75\%. Al cabo de 120 min de exposición se eliminó el $84 \%$ de las colonias. 


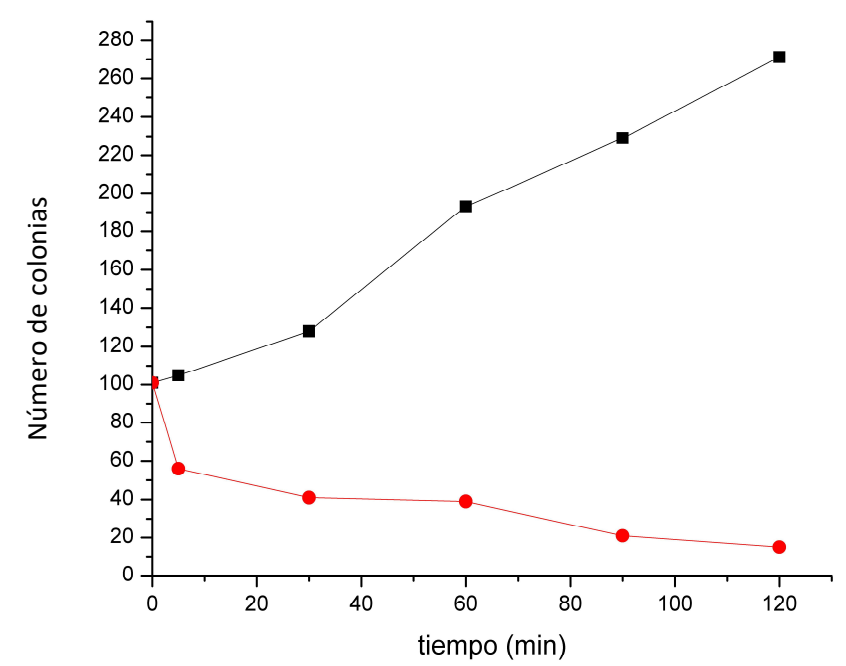

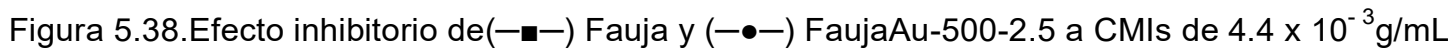
sobre el crecimiento de S. typhi.

El comportamiento de los materiales Silic y SilicAu-500-0.11 en tanto que bactericidas de la $S$. typhi se infiere de la figura 5.39. La presencia de Silic en el medio de cultivo no inhibe el crecimiento bacteriano, permitiendo su crecimiento durante los 120 min de exposición. Por otra parte, el SilicAu-500-0.11 eliminó al 58\% de las colonias en un tiempo muy corto (5 min).En los siguientes $55 \mathrm{~min}$, el efecto supresor del material SilicAu-500-0.11 fue aún más claro, eliminando el $75 \%$ de colonias. Enseguida se detecta una inhibición bactericida moderada. La CMI del material SilicAu-500-0.11 no fue suficiente para inhibir totalmente el microorganismo en un tiempo de 120 min, solo inhibió el 87\% del inóculo inicial sin presentar comportamiento bacteriostático en los 120 min del análisis. 


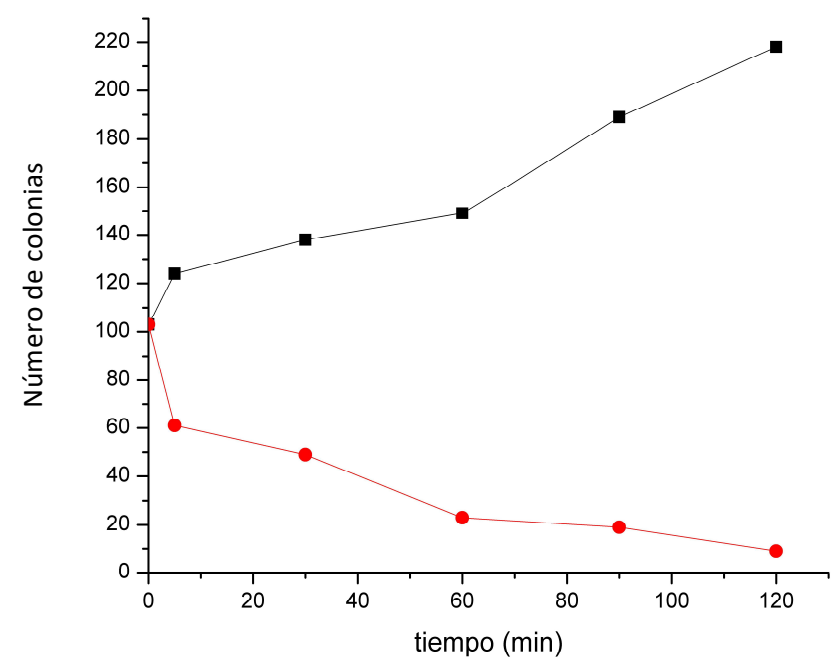

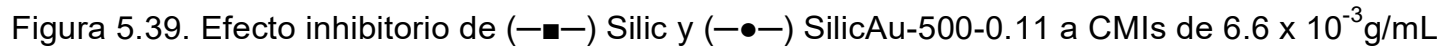
sobre el crecimiento de S. typhi.

Las curvas de crecimiento bacteriano se repitieron tres veces por material soporte-Au. Los resultados de las curvas corresponden a la media de los tres experimentos. Sólo se incluyen los experimentos en los que la inhibición del inóculo inicial fue superior al 55\%. La pauta de administración de los materiales bactericidas está en función de la CMI determinada.

En los cultivos de $S$. typhi en presencia de los materiales soporte-Au, independientemente del soporte, siempre se observó un efecto bactericida. De toda la serie de materiales evaluados, el material SilicAu-500-0.11, que además es el que tiene la menor concentración de Au, tuvo el mayor efecto inhibidor del crecimiento bacteriano con una CMI de $6.6 \times 10^{-3} \mathrm{~g} / \mathrm{mL}$, eliminando el $87 \%$ del inoculó inicial de S. typhi en un tiempo de $120 \mathrm{~min}$.

Los resultados de la exposición de $S$. typhia los materiales soporte-Au, mostraron que los materiales SilicAu-500-0.11 y MordeAu-500-2.9, no presentaron comportamiento bacteriostático en ningún momento.

El área específica del material soporte-Au fue relevante en la efectividad de los materiales para inhibir a los microorganismos. El material SilicAu-500-0.11 con la mayor área específicade los otros materiales soporte-Au logró una inhibición del 
crecimiento de las colonias de $S$. typhi similar a los otros materiales, aún cuando este material contiene una cantidad más baja de oro. Por ejemplo, el material SilicAu-500-0.11, con un área específica de $418 \mathrm{~m}^{2} / \mathrm{g}$, y con una concentración de Au 23.6 veces menor que el material FaujaAu-500-2.5, eliminó más rápido las colonias de S. typhi, inhibiendo el $87 \%$ del crecimiento de las colonias bacterianas a los 120 min, por otra parte el FaujaAu-500-2.5 con un área específica de 319 $\mathrm{m}^{2} /$ geliminó el $84 \%$ de las bacterias en el mismo tiempo. Esto se debe a que el tamaño de poro de la Silic es uno de los más pequeños en la serie de materiales evaluados y que este material no contiene aluminio, lo que permite que las partículas de oro de tamaño mediano $(5-7.5 \mathrm{~nm})$ se encuentren sobre la superficie y estén disponibles para las bacterias. Además, este soporte no incorpora $\mathrm{Au}^{3+}$ dentro de los poros. ElClinoAu-500-2.5 resultó ser el material con menor inhibición de $S$. typhi ya que el soporte ClinoNa tiene un alto contenido de aluminio pudiendo incorporar oro como catión dentro de sus cavidades, además este soporte es el de menor tamaño de poro de todos los materiales evaluados lo que provocó que las partículas de oro sobre las superficie externa fueran grandes y densas, perdiéndose una alta fracción de superficie metálica activa.

Los ensayos con materiales soporte-Au y cepas de E. coli o S. typhi, a concentraciones similares en un mismo soporte, difieren de lo observado con los materiales soporte-Ag donde la S. typhi presenta mayor resistencia a los materiales bactericidas. En los ensayos con todos los materiales soporte-Au y E. coli o S. typhi se observó similitud en la velocidad y porcentaje de eliminación de colonias. Esto puede atribuirse a la liberación del oro del material, el cual tiene mayor interacción con la célula bacteriana al penetrar en las bacterias.

El hecho de que las tendencias de las curvas para los materiales soporte- Ag y soportes-Au sean muy similares sin importar el tipo de bacteria, se debe en parte a que los métodos turbidimétricos son poco sensibles para detectar concentraciones celulares menores a $10^{7}$ (Dalgaard P.et al., 1994). También, es importante mencionar que la técnica turbidimétrica empleada no distingue entre células viables y no viables, por lo que a pesar de que en las curvas de crecimiento se observa una disminución en la población bacteriana, la tendencia 
en los valores de turbidez es a permanecer constante. No obstante, un efecto del soporte siempre estuvo presente en las series bactericidas zeolita-Ag y zeolita-Au. De manera general puede afirmarse que una capacidad baja de intercambio catiónico es deseable para prevenir que el material se localice en la superficie externa de la zeolita y sea accesible a las bacterias. Además, los cationes pequeños, altamente polarizantes, como $\mathrm{Na}^{+} \mathrm{y} \mathrm{H}^{+}$, son necesarios para polarizar cavidades y superficie externa y por tanto a las partículas metálicas. 


\section{Capítulo 6. Conclusiones y perspectivas}

\subsection{Conclusiones}

- Los materiales soporte-Ag y soporte-Au son agentes antibacterianos para E. coli y S. typhi. Su eficacia, reflejada por un radio CMB/CMI menor a 1.2, indica que los materiales son bactericidas y no bacteriostáticos.

- La CMI de los materiales varía en función de los soportes, la cantidad de plata u oro soportada en el material y la distribución de ésta en la superficie. El tamaño de las partículas es un parámetro crucial en su eficienciaantibacteriana.

- El soporte influencia la morfología de las partículas de plata y oro. Mientras que en los soportes se aglomeran fácilmente las partículas de plata, las del oro tienden a dispersarse, en general, mejor.Los materiales con mayor área específica resultan ser los mejores materiales para dispersar la fase activa metálica.

- La plata soportada en una matriz zeolítica, en particular en silicalita, es el mejor biocida para la E. coli y S. typhia cortos tiempos. El oro en el mismo soporte requiere de concentraciones mayores para eliminar totalmente a los microorganismos. 


\subsection{Perspectivas}

El tratamiento de aguas industriales, urbanas y de potabilización son algunas de las aplicaciones en las que pueden aplicarse los soportes-Ag y soportes-Au para cumplir con las normas mexicanas NOM-002-SEMARNAT-1996 y NOM-033SEMARNAT-1997, las cuales aplican en los índices de contaminación orgánica y biológica del agua ycon la norma NOM-127-SSA1-1994 relacionada con el consumo de agua.

Los materiales soportes-Ag y soportes-Au presentan las siguientes ventajas como bactericidas:

- Eliminan las bacterias en un único proceso "in situ" a tiempos cortos.

- El proceso se desarrolla a temperatura ambiente.

- Pueden ser usados como tratamiento terciario, en combinación con cualquier otro tipo de tratamiento convencional, lo que permite su fácil integración en procesos de potabilización de agua.

- El efecto bactericida de los materiales en cepas de distintos tipos y con un variado perfil de resistencias, el tiempo mínimo de exposición necesario para alcanzar el efecto antibacteriano y la poca resistencia bacteriana que se desarrolla a los materiales, convierten a estos materiales en elementos con gran potencial para la elaboración de múltiples productos que podrían utilizarse para evitar la propagación de microorganismos resistentes en el ambiente hospitalario, como filtros, recubrimientos, máscaras, y gasas antimicrobianas para las quemaduras. En la industria de alimentos, los materiales servirían de apoyo en la aplicación de bioconservantes alimentarios en la industria láctea y cárnica siendo un punto de partida en la industria de bioconservantes de origen natural.

- Un buen complemento a las ventajas del uso de la plata y el oro es su baja toxicidad y mínimos efectos secundarios. 


\section{Bibliografía}

- Agencia de Protección Ambiental de las Naciones Unidas EPA. In-depth Studies on Health and Environmental Impacts of Selected Water Pollutants. 1978, Contract 68-01-4646.

- Alberti A., Vezzalini G., Crystal structures of heat-collapsed phases of barrerite. In Natural Zeolites, Occurrence, Properties Use. Sand, L.B. and Mumpton, Eds Pergamon Press, 1978, 85-98.

- American Society of Engineers American Water Works Association, Water Treatment Plant Design, 2nd Edition, 1990, 501-507.

- Anales de la real academia nacional de medicina, Coloquio sobre contaminación ambiental, Real Academia Nacional de Medicina, España, 1975, 1, 171-178.

- Bekkum H., Flanigen E., Studies in Surface Science and Catalysis; Elsevier Science B., 1991, 58-59.

- Belliveau B., Starodub M., Cotter C., Trevors, J., Metal resistence and accumulation in bacteria. Department of Environmental Biology, University of Guelph. 1987, 5, 27-101.

- Bosch P., Schifter I., La zeolita una piedra que hierve. Fondo de Cultura Económica, México, D.F., 1997.

- Brock T., Madigan M., Biology of Microorganisms. Ed. Prentice Hall, 5th edition. 1988, 835-842.

- Cervantes C., Bacterias que expulsan metales pesados. Información Científica y Tecnológica, 1992, 14,13-17.

- Cervantes C., Minerales que expulsan metales pesados. Instituto de Investigaciones Químico-Biológicas, Universidad Michoacana de San Nicolás de Hidalgo. SPECTRA, 1992.

- Cervantes C., Vargas E., Álvarez A., Sistemas bacterianos de expulsión de metales tóxicos, Revista Latinoamericana de Microbiología, 1998, 4053. 
- Charles J., Nanosilver as a biocide in building materials. 2006. US 0272542, 4-5.

- Chmielewska D., Łukasiewicz A., Waliś L., Water soluble silica biocides containing quaternary ammonium salts. In: INCT Annual Report, 2006, 141-153.

- Cho K., Park J., Osaka T., Park S., The study of antimicrobial activity and preservative effects of nanosilver ingredient. Electrochimica Acta, 2005, 51, 956-960.

- Clement J., Jarrett P. S., Antimicrobial silver. Metal based Drugs, 1994, 1, 467-482.

- Cooper R., A review of the evidence for the use of topical antimicrobial agents in wound care, World Wide Wounds, 2004.

- Csicsery S., Zeolite Chemistry and Catalysis, ACS Monograph, J. A. Rabo Edition, 1985, 171, 680-713.

- Dalgaard P., Ross T., Kamperman L., Neumeyer K., McMeekin T., Estimation of bacterial growth rates from turbidimetric and viable count data. International Journal of Food Microbiology, 1994, 23, 391-404.

- Damm C., Münstedt H., Rösch A., The antimicrobial efficacy of polyamide 6/silver-nano and microcomposites. Materials Chemistry and Physics, 2008,108, 61-66.

- Davis M., Zeolites and molecular sieves: not just ordinary catalysts. Industrial \& Engineering Chemistry Research. 1991, 30, 1675.

- Day R., Furst D., Van Riel P., Bresnihan B., Progress in inflammation research, Antirheumatic Therapy: Actions and Outcomes, Michael J. Parnham Series Editor, 2005, 49-68.

- Demling R., De Santi L. Wounds. Scar management strategies in wound care. Rehabilitation Management, 2001, 14, 26-30.

- Derouane E., Zeolites Science and Technology, NATO ASI Series, F.R. Ribeiro et al. Eds., 1984, 80, 347-348. 
- Dibrov P., Dzioba J., Khoosheh K., Gosink, Häse C., Chemiosmotic Mechanism of Antimicrobial Activity of $\mathrm{Ag}^{+}$in Vibrio cholerae. Antimicrobial Agents and Chemoteraphy, American Society for Microbiology, 2002, 46, 2268-2670.

- Dwyer J., Zeolite structure, composition and catalysis, Chemistry \& Industry, 1984, 7, 258.

- Dyer A., An introduction to zeolite molecular sieves. John Wiley and Sons Inc., 2008, 82-99.

- EdelmanR., LevineM., Summary of an international workshop on typhoid fever. Journal of Infectious Diseases, 1986, 8, 49-329.

- Esteban A., Evidence-based management of patients with respiratory failure, update in intensive care medicine, Jean-Louis Vincent Edition, 2005, 81-162.

- Feng Q., Wu J., Chen G., Cui F., Kim T., and Kim J., A mechanistic study of the antibacterial effect of silver ions on Escherichia coli and Staphylococcus aureus, Journal of Biomedical Materials Research, 2000, $52,662-668$.

- Fricker S., Medicinal chemistry and pharmacology of gold compounds, Transition Metal Chemistry, 1996, 21, 377-383.

- FSIS, Food Safety and Inspection Service, United States Department of Agriculture, New performance standards for salmonella and campylobacter in chilled carcasses at young chicken and turkey slaughter establishments, 2011.

- Fyfe C., Feng Y., Grondey H., Kokotailo G., Mar A., Natural abundance, two-dimensional silicon-29 MAS NMR investigation of the threedimensional bonding connectivities in the high- and low-temperature forms of zeolite ZSM-11, The Journal of Physical Chemistry, 1991, 95, 37473751 .

- García J., Rodríguez E., Ortiz C., Coutiño R., Efecto bactericida de los derivados de plata coloidal, cal y cloro en lechuga romana sin 
y con lavado, Revista Higiene, 2004,1,150-161.

- Garry G., Graham G., Champion D., Ziegler J., The cellular metabolism and effects of gold complexes, Metal Based Drugs 1, 1994, 395-404.

- Gemmell C., Edwards D., Fraise A. et al., Guidelines for the prophylaxis and treatment of methicillin-resistant Staphylococcus aureus (MRSA) infections in the UK Journal of Antimicrobial Chemotherapy, 2006, 57, 589-608.

- Geobaldo F., Bordiga S., Zecchina A., Giamello E., Leofanti G., Petrini G., DRX UV-VIS and EPR spectroscopy of hydroperoxo and superoxo complexes in titanium silicalite, Catalysis letters, 1992, 16, 109-115.

- Goodman A., Gilman S., Las bases farmacológicas de la terapéutica. Editorial Panamericana, 6ta. Edición. 1982, 57-68.

- Gottardi G., Mineralogy and Crystal Chemistry of Zeolites: in natural zeolites, L.B. Sand and F.A., Mumpton Eds., 1978, 31-44.

- Harrison A., Fractals in Chemistry. Oxford University Press Inc., 1995.

- Herikstad H., Hayes P., Mokhtar M., Fracaro M., Threlfall E., Angulo F., Emerging quinolone-resistant Salmonella in the United States. Emerging Infectious Diseases, 1997, 3, 371-372.

- Hugo W., Russell A., Principles and Practice of Disinfection, Preservation and Sterilisation. $3^{\text {rd }}$ Ed., Blackwell Scientific Publications, 1995, 5-94.

- Im K., Takasaki Y., Endo A., Kuriyama M., Antibacterial Activity of A- Type Zeolite Supporting Silver lons in Distilled Water. Journal of Antibacterial and Antifungal Agents, 1996, 24, 269-274.

- Kawahara K., Tsuruda K., Morishita M., Uchida M., Antibacterial effect of silver-zeolite on oral bacteria under anaerobic conditions. Dental Materials, 2000, 16, 452-455.

- Kesraoui-Ouki S., Cheeseman C., Perry R., Natural zeolite utilization in pollution control: a review of applications to metals' effluents. Journal of Chemical Technology and Biotechnology, 1994, 59, 121-126. 
- Klein D., Lansing M., Harley J., Microbiology. WCB/McGraw-Hill. 1999, 294-301.

- Landeen K., Yahya M., Gerba C., Efficacy of copper and silver ions and reduced levels of free chlorine in inactivation of legionella pneumophila. American Society for Microbiology, Applied and Environmental Microbiology, 1989, 55, 3045-3050.

- Langella A., Pansini M., Cappelletti P., de Gennaro B., de Gennaro M., Colella C., $\mathrm{NH}^{4+}, \mathrm{Cu}^{2+}, \mathrm{Zn}^{2+}, \mathrm{Cd}^{2+}$ and $\mathrm{Pb}^{2+}$ exchange for $\mathrm{Na}^{+}$in a sedimentary clinoptilolite, North Sardinia, Italy, Microporous and Mesoporous Materials, 2000, 37, 337-343.

- Lapotko D., Lukianova E., Potapnev M., Aleinikova O., Oraevsky A., Method of laser activated nanothermolysis for elimination of tumor cells. Cancer Letters 239, 2006, 36-45.

- Lara H., Ayala-Nuñez N., Ixtepan-Turrent L., Rodriguez-Padilla C., Bactericidal effect of silver nanoparticles against multidrug-resistant bacteria.World Journal of Microbiology and Biotechnology, 2010, 26, 615621.

- Leyva R., Aguilar A., González G., Guerrero C., Mendoza B., Ammonia exchange on clinoptilolite from mineral deposits located in Mexico, Journal of Chemical Technology and Biotechnology, 2004, 79, 651-657.

- Macarulla J., Goñi F., Bioquímica humana, Editorial Reverté, S.A., Segunda Edición, 1994, 161-165.

- Maillard J., Bacterial target sites for biocide action. Journal of applied Microbiology Symposium Supplement, 2002, 92, 16-27.

- Martin A., Colloids, Physical Pharmacy and Pharmaceutical Sciences, Ed. Sinko PJ $5^{\text {th }}$ Edition., Lippincott Williams \& Wilkins, 2006, 469-498.

- McDonell G., Russell A., Antiseptics and desinfectants. Clinical Microbiology Reviews, 1999, 12, 147-179. 
- McKeage M., Maharaj L., Berners-Price S.,Mechanisms of cytotoxicity and antitumor activity of gold(I) phosphine complexes: the possible role of mitochondria, Coordination Chemistry Reviews, 2002, 232, 127-135.

- Meier W., Olson D., Baerlocher C., Atlas of Zeolite framework types, Elsevier, 2007, 17, 1-229.

- Meier W., Olson D., Baerlocher Ch., Atlas of Zeolite Structure Type, $4^{\text {th }}$ Revised Edition, 1996.

- Muñoz R., Collazo P., Alvarado F., Efecto bactericida de la cal hidratada en solución acuosa. Oficina Sanitaria Panamá, 1995, 118, 302-305.

- Murray R., Bioquímica de Harper. México, Editorial El Manual Moderno, 2010, 69-98.

- Nataro J., Enteroaggregative Escherichia coli pathogenesis. Current Opinion in Gastroenterology, 2005, 21, 4-8.

- Nataro J., Kaper J., Diarrheagenic Escherichia coli., Clinical Microbiology Reviews., 1998, 11, 142-201.

- Nataro J., Mai V., Johnson J., Diarrheagenic Escherichia coli infection in Baltimore, Maryland, and New Haven, Connecticut. Clinical Infectious Diseases, 2006, 43, 402-407.

- NMX-AA-42-SCFI-1987. Calidad del agua determinación del número más probable (NMP) de coliformes totales, coliformes fecales (termotolerantes) y Escherichia coli presuntiva. Secretaría de Comercio y Fomento Industrial, Dirección General de Normas. 2000.

- NOM-002-SEMARNAT-1996, Norma Oficial Mexicana que establece los límites máximos permisibles de contaminantes en las recargas de aguas residuales a los sistemas de alcantarillado urbano o municipal, 1998.

- NOM-033-SEMARNAT-1997, Norma oficial Mexicana que establece los límites máximos permisibles de contaminantes para las aguas residuales tratadas que se reusen en servicio al público, 1998. 
- NOM-127-SSA1-1994, Norma Oficial Mexicana, Salud ambiental, agua para uso y consumo humano-Límites permisibles de calidad y tratamientos a que debe someterse el agua para su potabilización, 1995.

- Nomiya K., Yamamoto S., Noguchi R., Yokoyama H., Kasuga N., Ohyama K., Kato C., Ligand-exchangeability of 2-coordinate phosphinegold(I) complexes with AuSP and AuNP cores showing selective antimicrobial activities against Gram-positive bacteria. Crystal structures of [Au(2$\mathrm{Hmpa})(\mathrm{PPh}(3))] \quad$ and $\quad[\mathrm{Au}(6-\mathrm{Hmna})(\mathrm{PPh}(3))] \quad$ (2- $\quad \mathrm{H}(2) \mathrm{mpa}=2-$ mercaptopropionic acid, 6-H(2)mna=6-mercaptonicotinic acid). Journal of Inorganic Biochemistry, 2003, 95, 208-228.

- Novelli F., Recine M., Sparatore F., Juliano C., Triorganotin compounds as antimicrobial agent, II Farmaco, 1999, 54, 237-241.

- Orha C., Manea F., Pop A., Burtica G., Todea I. F., Obtaining and characterization of zeolitic materials with antibacterial properties, Revista de Chimie, 2008, 59, 173-177.

- Panácek A., Kvítek L., Prucek R., Kolár M., Vecerová R., Pizúrová N. et al., Silver colloid nanoparticles: synthesis, characterization, and their antibacterial activity. Journal of Physical Chemistry B, 2006, 110, 1624816253.

- Perego G., Bellusi G., Corno C., Taramsso M., Buonomo F., Esposito A., Titanium-silicate: a novel derivative in the pentasil family, Proceedings 7 th Int. Zeolite conference Tokyo, Kodansha Publishing., 1986, 129.

- Pumarola A., Microbiología y parasitología médica, MASSON, S. A., $1987,12-16$.

- Rai M., Yadav A., Gade A., Silver nanoparticles as a new generation of antimicrobials, Biotechnology Advances, 2009, 27, 76-83.

- Ronald M., Principles of Microbiology. Editorial Mosby, 1995, 43-55.

- Rosabal B., Rodríguez G., Bogdanchikova N., Bosch P., Lara V., Prakash A., Comparative study of natural and synthetic clinoptilolites 
containing silver in different states. Microporous and Mesoporous Materials, 2005, 86, 249-255.

- Rowe B., Ward L., Threlfall E., Multidrug-resistant Salmonella Typhi: a worldwide epidemic. Clinical Infectious Diseases, 1997, 24, 106-117.

- Russell A., Similirities and differences in the responses of microorganisms to biocides. Journal of antimicrobial chemotherapy. 2003, 52, 750-763.

- Ruttler M., Renna N., Balbi L., Garcia B., Guidone L., Fernandez R., Puig O. \& Ortiz, A., Characterization of enteroaggregative Escherichia coli strains isolated from children with acute diarrhea, in Mendoza, Argentina. Revista Argentina de Microbiología, 2002, 34, 167-170.

- Sadler P., Lectures in Bionorganic Chemistry, Cortina International, 1991, $1-24$.

- Shahverdi A., Fakhimi A., Shahverdi H., Minaian S., Synthesis and effect of silver nanoparticles on the antibacterial activity of different antibiotics against Staphylococcus aureus and Escherichia coli, Nanomedicine, 2007, 3,168-171.

- Sigler J., Bluhm B., Duncan H., Sharp T., Ensing D., McCurry W., Arthitis Rheumatism, 1972, 15, 125.

- Silver S., Bacterial interactions with mineral cations and anions: good ions and bad, Eds. P. Westbroek \& W. Jong, 1983, 439-457.

- Silver S., Bacterial silver resistance: molecular biology and uses and misuses of silver compounds, FEMS Microbiology, 2003, 27, 341-354.

- Silver S., Misra T., Laddaga R. , ADN sequence analysis of bacterial toxic heavy metal resistances, Biological Trace Element Research, Humana Press Inc., 1989, 21, 145-163.

- Skandamis P., Koutsoumanis K., Fasseas K., Nychas G., Inhibition effect of oregano essential oil and EDTA on Escherichia coli O157-h7. International Journal of Food Science and technology, 2001, 13, 65-75. 
- Sociedad Argentina de terapia intensiva, Infecciones por catéteres vasculares: En situaciones particulares. Ed. Médica Panamericana, 2003, 2, 97-101.

- Sondi I., Salopek-Sondi B., Silver nanoparticles as antimicrobial agent: a case study on E. coli as a model for gram-negative bacteria. Journal of Colloid and Interface Science, 2004, 275, 177-182.

- Stobie N., Duffy B., McCormack D., Colreavy J., Hidalgo M., McHale P. et al., Prevention of Staphylococcus epidermidis biofilm formation using a low-temperature processed silver-doped phenyltriethoxysilane sol-gel coating. Biomaterials, 2008, 29, 963-972.

- Struther J., Westran P., Bacteriología clínica, Editorial Masson, S. A., 2005, 10-165.

- Taramasso M., Perego G., Notari B., "Preparation of porous crystalline synthetic material comprised of silicon and titanium oxides", Patente USA 4410501, 1983.

- Tenorio J., Espinosa D., Treatment of chromium plating process effluents with ion exchange resins, Waste Management, 2001, 21, 637-642.

- Thurman R., Gerba C., The molecular mechanisms of copper and silver ion disinfection of bacteria and viruses, Critical Reviews of environmental control, 1989, 18, 295-315.

- Torres M., Tratado de cuidados críticos y emergencias, Tomo II, Ediciones ARAN, 2002, 1343-1576.

- Tortora G., Berdell R. Funke, Christine L. Case, Introducción a la microbiología, 9a edición, Ed. Médica Panamericana, 2007, 69-89.

- Tuel A., Diab J., Gelin P., Dufaux M., Dutel J., EPR evidence for the isomorphous substitution of titanium in silicalite structure. Journal of molecular catalysis, 1990, 63, 95-96.

- Tuovinen 
- O., Puhakka J., Hiltunen P., and Dolan K., Silver toxicity to ferrous iron and pyrite oxidation and its alleviation by yeast extract in cultures of thiobacillus ferrooxidans. Journal of Biotechnology Letters, 1985, 7, 38994.

- Vaughan D., Properties and Application of Zeolites, R. P. Townsend Ed., Society of Chemical Industry, 1980, 294-295.

- Ward J., Williams H., Egger M., Reading J., et al., Comparison of auranofin, gold sodium thiomalate, and placebo in the treatment of rheumatoid arthritis. American College of Rheumatology, Arthritis and Rheumatism, 1983, 26, 1303-1315.

- Weber W., Control de la calidad del agua: procesos fisicoquímicos, Editorial Reverté, S. A., 2003, 301-305.

- Weidauer E., Yasuda Y., Biswal B., Cherny M., James M., Brömme D.,Effects of disease-modifying anti-rheumatic drugs (DMARDs) on the activities of rheumatoid arthritis-associated cathepsins $\mathrm{K}$ and S,Biological Chemistry, 2007, 388, 331-336.

- World Health Organization (WHO). The world health report 1996: Fighting disease, fostering development. Geneva, WHO, 1996, 143.

- Wright V., Oral gold for rheumatoid arthritis, British Medical Journal, 1984, 289, 858-859.

- Yan J., Cheng J., Antimicrobial yarn having nanosilver particles and methods for manufacturing the same. 2005, US6979491.

- Yin H., Langford R., Burrell R., Comparative evaluation of the antimicrobial activity of Acticoat antimicrobial barrier dressing, Journal of Burn Care Rehabilitation, 1999, 20, 195-200. 


\section{Artículos}

Los siguientes artículos fueron publicados con los principales resultados de esta tesis:

- Roberto Guerra, Enrique Lima, Margarita Viniegra, Ariel Guzmán, Víctor Lara, Growth of Escherichia coli and Salmonella typhi inhibited by fractal silver nanoparticles supported on zeolites, Microporous and Mesoporous Material, 2012, 147, 267-273.

- Roberto Guerra, Enrique Lima, Ariel Guzmán, Antimicrobial supported nanoparticles: Gold versus silver for the cases of Escherichia coli and Salmonella typhi, Microporous and Mesoporous Material, 2013, 170, 62-66.

- Enrique Lima, Roberto Guerra, Víctor Lara, Ariel Guzmán, Gold nanoparticles as efficient antimicrobial agents for Escherichia coli and Salmonella typhi Chemistry Central Journal, 2013, 7:11. 
PARTICUYAS DE PLATA Y ORO HOSPEDADAS EN MATERIALES

POROSOS. Y SU EFICIENCIA COMO

BACTER ICIDAS.
En México, D.F., se presentaron a las 13:00 horas del día 31 del mes de enero del año 2013 en la Unidad Iztapalapa de la universidad Autónoma Metropolitana, los suscritos miembros del jurado:

$$
\begin{aligned}
& \text { DR. MAXIMILIANO JOEL ASOMOZA PALACIOS } \\
& \text { DR. JUAN MENDEZ VIVAR } \\
& \text { DR. ENRIQUE JAIME LIMA MUITOZ } \\
& \text { DR. ARIEL GUZMAN VARGAS } \\
& \text { DRA. JULIA AGUILAR PLIEGO }
\end{aligned}
$$

Bajo la Presidencia del primero y con carácter de Secretaria la última, se reunieron a la presentación de la Disertación pública cuya denominación aparece al margen para la obtención del grado de:

DOCTOR EN CIENCIAS (QUTMICA)

DE: ROBERTO GUERRA GONZALEZ

y de acuerdo con el artículo 78 fxacción IV del Reglamento de Estudios Superiores de la Universidad Autónoma Metropolitana, los miembros del jurado resolvieron:

\section{APROBAR}

Acto continuo, el presidente del jurado comunicó al interesado el resultado de la evaluación $y$, en caso aprobatorio, le fue tomada la protesta.

LIC. JULIO CESAR DE LARAYSASSI DIRECTOR DE SISTENAS ESCOLARES
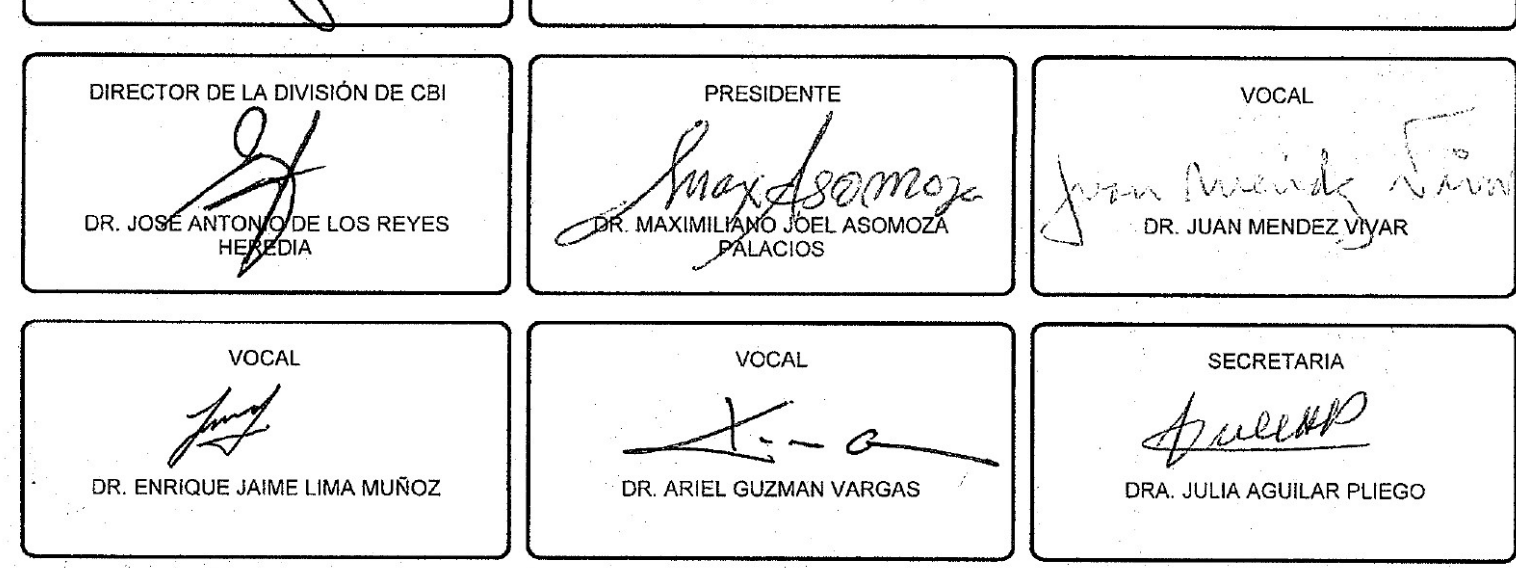